
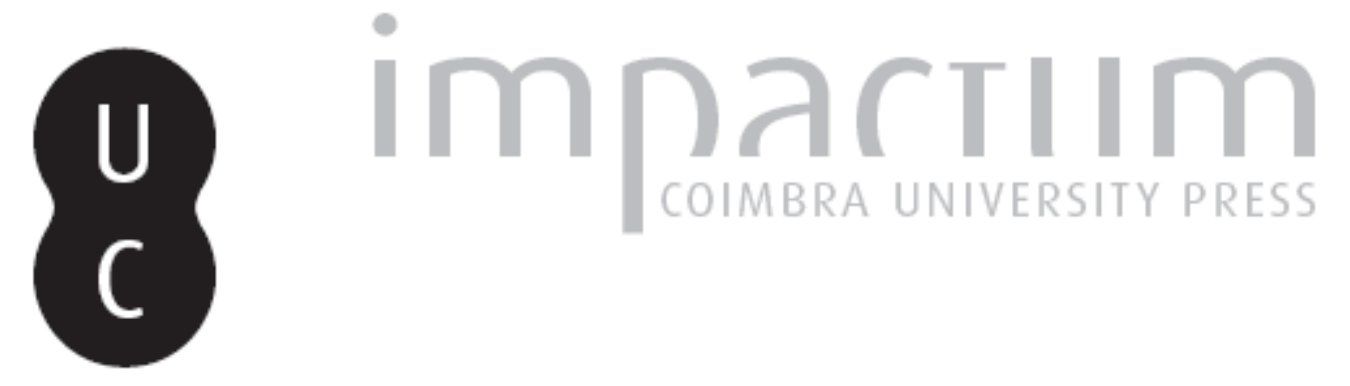

\title{
A diocese de Coimbra no século XVIII: população, oragos, padroados e títulos dos párocos
}

Autor(es): $\quad$ Carvalho, Joaquim; Paiva, José Pedro

Publicado por: Imprensa da Universidade de Coimbra

URL persistente:

http://hdl.handle.net/10316.2/42915

DOI:

https://doi.org/10.14195/2183-8925_11_8

Accessed : $\quad$ 26-Apr-2023 09:41:56

A navegação consulta e descarregamento dos títulos inseridos nas Bibliotecas Digitais UC Digitalis, UC Pombalina e UC Impactum, pressupõem a aceitação plena e sem reservas dos Termos e Condições de Uso destas Bibliotecas Digitais, disponíveis em https://digitalis.uc.pt/pt-pt/termos.

Conforme exposto nos referidos Termos e Condições de Uso, o descarregamento de títulos de acesso restrito requer uma licença válida de autorização devendo o utilizador aceder ao(s) documento(s) a partir de um endereço de IP da instituição detentora da supramencionada licença.

Ao utilizador é apenas permitido o descarregamento para uso pessoal, pelo que o emprego do(s) título(s) descarregado(s) para outro fim, designadamente comercial, carece de autorização do respetivo autor ou editor da obra.

Na medida em que todas as obras da UC Digitalis se encontram protegidas pelo Código do Direito de Autor e Direitos Conexos e demais legislação aplicável, toda a cópia, parcial ou total, deste documento, nos casos em que é legalmente admitida, deverá conter ou fazer-se acompanhar por este aviso.

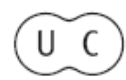


REVISTA DE HISTÓRIA DAS IDEIAS 11

\section{CULTURA POLÍTICA MENTALIDADES}

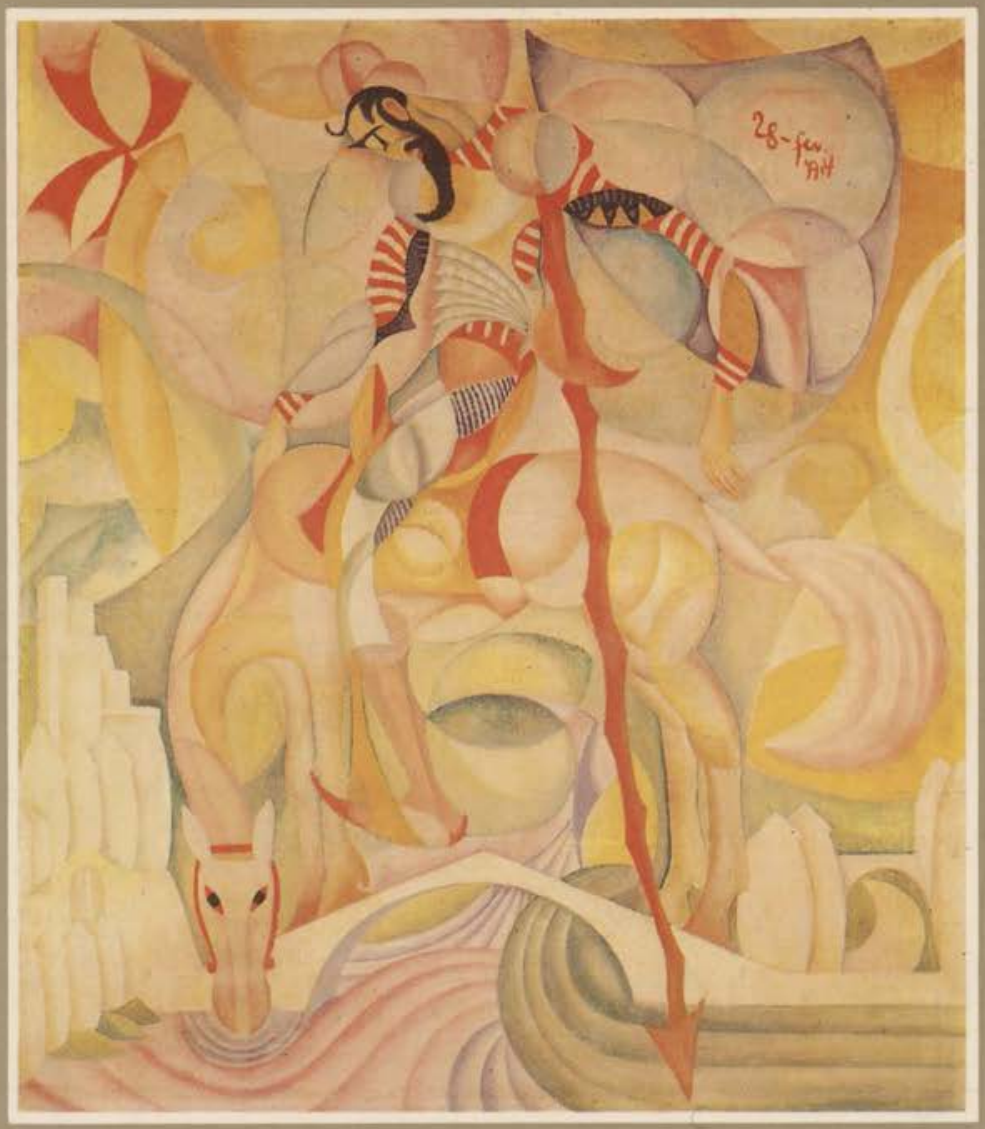

INSTITUTO DE HISTORIA E TEORIA DAS IDEIAS FACULDADE DE LETRAS 


\section{A DIOCESE DE COIMBRA NO SÉCULO XVIII POPULAC̄̃̃O, ORAGOS, PADROADOS E TÍTULOS DOS PÁROCOS}

\section{Introdução}

Este artigo apresenta alguns resultados da investigação que os autores têm desenvolvido no âmbito da história da diocese de Coimbra, e incide particularmente sobre os problemas relativos à caracterização geográfica do território diocesano. $\mathrm{O}$ ponto de partida desta investigação foi o estudo das visitas pastorais da diocese, documentação de excepcional riqueza para a história sócio-religiosa.

Em trabalho anterior descrevemos as características principais da evolução da actividade visitacional dos preiados entre 1650 e $1775-83\left({ }^{1}\right)$. De uma análise cronológica decidiu-se passar a um estudo geográfico. 0 seu objectivo principal é o de tentar descobrir se existem ou não "zonas» distintas ao nível das atitudes religiosas dentro da vasta área da diocese de Coimbra no Antigo Regime. Embora as visitas pastorais fornecessem elementos importantes para essa diferenciação espacial, é evidente que é necessário relacionar informação muito variada para a caracterização do território a analisar. Assim, surgiu a ideia de empreender um estudo mais alargado da vida diocesana. Com essa finalidade foram recolhidas informações que nos permitem, entre outros aspectos, saber qual era aproximadamente o total da população que habitava em cada freguesia, quais eram os seus oragos, quem apresentava os párocos, qual a proveniência geográfica dos sacerdotes, os locais onde existiam relíquias e milagres,

* Faculdade de Letras da Universidade de Coimbra.

(1) Joaquim Carvalho e José Pedro Paiva, "A evolução das visitas pastorais da diocese de Coimbra nos séculos XVII e XVIII», Ler História, n. ${ }^{\circ} 15,1989$, pp. 29-41. 
a distribuição das principais instituições de assistência (como hospitais, misericórdias e casas de recolhimento), a rede da implantação de congregações religiosas, etc. A análise de todos estes dados, levou à necessidade de criar um sistema que permitisse representar rapidamente, sob a forma de mapas, a distribuição geográfica dos valores recolhidos. Esse sistema, a funcionar actualmente em equipamento informático do Arquivo da Universidade de Coimbra, é capaz de cartografar variáveis históricas, e permitir ao utilizador uma análise interactiva dos dados.

Apresentamos aqui apenas parte da informação recolhida até agora, aquela que, de certo modo, representa algumas das estruturas fundamentais do território diocesano. Esperamos poder brevemente complementar este primeiro quadro com a apresentação de outros aspectos relevantes para a caracterização geográfica da diocese de Coimbra, incidindo aí sobre os aspectos comportamentais ligados à vivência religiosa das populações (vocações, fundações de capelas, festas, pecados públicos, etc.).

$\mathbf{O}$ texto está organizado do seguinte modo. Em primeiro lugar focaremos, com algum detalhe, os procedimentos utilizados para o estabelecimento da carta da diocese de Coimbra, nos séculos XVII e XVIII. Segue-se uma descrição das características geográficas do espaço em questão. Num terceiro ponto, fornecemos uma imagem, forçosamente genérica, da distribuição populacional da diocese. Os oragos das paróquias ocupar-nos-ão seguidamente. $\mathbf{O}$ aspecto fundamental do direito de apresentação dos párocos será tratado a seguir. Finalmente mostraremos as variações regionais das denominações dos párocos.

Como veremos, em todos estes aspectos é constatável a existência de regiões diferenciadas no interior do vasto território da diocese de Coimbra. Sempre que possível procuraremos determinar as origens dessas interessantes diferenciações.

As principais fontes utilizadas foram as várias corografias impressas do século XVIII, assim como diversas informações paroquiais manuscritas da mesma época. Foi nossa preocupação recolher nestas fontes o maior número possível de informações diferentes, controlá-las reciprocamente, recorrendo, sempre que necessário, a documentação auxiliar, de que destacamos as visitas pastorais e os processos de colação de párocos. 
1. Estabelecimento do território da diocese nos séculos XVII e XVIII e elaboração da carta de referência

Os vários cartogramas apresentados neste trabalho foram produzidos por meios informáticos a partir de um mapa base, a que chamamos "mapa de referência». A sua elaboração levantou três tipos de problemas: 1) saber quais as paróquias que compunham a diocese nos séculos XVII e XVIII; 2) saber quais as fronteiras que essas paróquias tinham na época em questão; 3 ) implementar um procedimento automático que permitisse a representação cartográfica das variáveis de que dispunhamos, paróquia a paróquia. $\mathrm{O}$ último ponto, sendo de natureza técnica e informática, não será aqui tratado $\left({ }^{2}\right)$. Os processos usados para saber quais as paróquias da diocese e quais os seus limites serão descritos a seguir.

Os levantamentos das visitas pastorais, efectuados em trabalhos anteriores, forneceram o núcleo principal das paróquias da diocese de Coimbra. Segundo a legislação tridentina, todas as igrejas onde se prestasse cura de almas estavam sujeitas à actividade visitacional do bispo. Assim. o prelado, ou os visitadores seus delegados, tinham por obrigação visitar todas as igrejas da diocese anualmente, ou pelo menos, de dois em dois anos. Estas determinações implicam que os documentos produzidos pelas visitas pastorais são, em princípio, um bom guia para o conhecimento dos territórios diocesanos. Na prática, contudo, a legislação tridentina chocou com inúmeros privilégios anteriores que isentavam certos territórios da actividade inspeccionadora dos prelados. $\mathbf{O}$ exemplo da diocese de Braga é muito significativo a este respeito. Aí ocorreram inúmeros conflitos entre o bispo. o cabido e a colegiada de Guimarães sobre o exercício do direito de visita, conflitos nem sempre resolvidos a favor do prelado $\left({ }^{3}\right)$. Na diocese de Coimbra não temos notícia de conflitos

(2) O equipamento e as técnicas informáticas utilizadas foram objecto de uma comunicação/demonstração apresentada pelos autores do presente trabalho. ao segundo encontro da Associação Portuguesa de História e Informát:ca intitulada Cartografia automática $e$ análise de dados históricos, Braga, Abril de 1989.

(3) Veja-se a este respeito o trabalho de Franquelin Neiva Soares $A$ arquidiocese de Braga no século XVI. Visitas Pastorais e livros de Visitações, dissertação de licenciatura apresentada à Faculdade de Letras do Porto, dact., 2 vols., Porto, 1972 e do mesmo autor Visitações de D. Fr. Baltasar Limpo na Arquidiocese de Braga. Visitaçôes à 
semelhantes. Os únicos territórios que nesta diocese escapavam à acção da visita episcopal eram os que pertenciam ao isento de Santa Cruz, como veremos.

As fontes deixadas pelas visitas pastorais mostram que a diocese se compunha de 369 paróquias, divididas em quatro zonas (cidade de Coimbra e arcediagados de Penela, Seia e Vouga), que correspondiam a unidades importantes do ponto de vista da organização interna da administração diocesana. Assim, as visitas pastorais eram efectuadas por arcediagados, com uma visita separada para a cidade. Muita da documentação diocesana está organizada em função destas quatro zonas $\left({ }^{4}\right)$.

Refira-se ainda a existência no interior dos limites da diocese de 7 freguesias que escapavam à jurisdição episcopal, não sendo portanto visitadas. Tratava-se das paróquias que faziam parte do isento de Santa Cruz (nullius diocesis), que apesar das determinações de Trento conseguiu manter privilégios de isenção mesmo em relação à actividade visitacional do bispo $\left({ }^{5}\right)$. As freguesias nesta situação, e que estavam como que encravadas no interior da diocese de Coimbra,

colegiada de Nossa Senhora de Oliveira e outras igrejas da região de Guimarães, 2.a ed. corrig.da e ampliada, Braga, 1983. Ocorreram também conflitos entre bispos e os visitadores das ordens militares, nomeadamente em Évora, nas terras de jurisdição da Ordem de Santiago, com constantes intervenções do rei e do papa, com cenas de violência e acordos não cumpridos (pode-se ver toda uma série de cartas régias e sentenças em Andrade e Silva, Collecção Chronológica da Legislação Portugeza, Lisboa, 1854, datas de 14/10/1625, 31/1/1626, $28 / 7 / 1626,22 / 12 / 1632,23 / 12 / 1637,25 / 5 / 1639,20 / 2 / 1640$ e $3 / 10 / 1640$.

(4) O investigador interessado em localizar documentação respeitante a determinada paróquia no fundo da Mitra e Cabido do AUC (Arquivo da Universidade de Coimbra, a partir de agora usar-se-á sempre a versão abreviada), necessita, em muitos casos, de saber o arcediagado correspondente, uma vez que a documentação diocesana está organizada neste sentido. 0 melhor meio para obter uma visão geral deste fundo documental é o Boletim do Arquivo da Universidade de Coimbra, 1973, vol. I, pp. 104-142. O fundo das visitas pastorais foi inventariado pelos autores do presente artigo no "Repertório das visitas pastorais da Diocese de Coimbra, séculos XVII, XVIII e XIX» Boletim do Arquivo da Universidade de Coimbra, 1985, vol. VII, pp. 111-214. A lista de freguesias que publicamos em apêndice permite saber o arcediagado de cada uma das paróquias da diocese.

(5) Como já acima se referiu, em Trento determinou-se que todos os lugares onde existisse cura das almas ficavam sujeitos à visitação episcopal. Por outro lado, é reconhecido o aumento dos poderes episcopais depois de Trentc A prova da isenção de visita episcopal de que gozavam os Crúzios é dada contudo por um documento publicado por Rocha Madahil. Em 1786, o prelado de Santa 
eram as da Tocha (ou Quintã), Travassô, Ribeira de Frades, Travanca, Antuzede, Eirol e Santa Cruz na cidade de Coimbra $\left({ }^{6}\right)$.

Reconstituída a lista das paróquias, foi necessário encontrar um modo de representar num mapa os seus limites territoriais, de modo a elaborar cartogramas que permitissem analisar a distribuição geográfica de elementos recolhidos nas fontes estudadas.

A reconstituição do território das antigas paróquias parte da dificuldade de não existirem representações cartográficas da época com os limites paroquiais. De facto, tanto quanto sabemos, o primeiro mapa com o limite das freguesias, a nível nacional, foi elaborado em 1948 sob a direcção de Amorim Girão, no Centro de Estudos Geográficos da Faculdade de Letras de Coimbra $\left({ }^{7}\right)$. $\mathrm{O}$ empreendimento só

Cruz interpôs no Juízo da Corôa um recurso devido a abusos dos ministros da relação eclesiástica de Coimbra na ausência do bispo de então, D. Francisco de Lemos. Na sua exposição dizia o prelado a certo passo: "....nunca em tempo algum mandaram os bispos de Coimbra publicar as suas pastorais e mandamentos nas igrejas do território de Santa Cruz. Nunca visitando a cidade ou bispado foram chamados às ditas visitas os súbditos do isento....». Cf. António Rocha Madahil, Os privilégios do isento de Santa Cruz de Coimbra, Coimbra, 1940, p. 53. Esclareça-se. contudo, que estes territórios do isento de Santa Cruz eram visitados por um visitador, nomeado pelo próprio convento, existindo documentos que o comprovam. Cf. AUC, Livro de visitas às freguesias de Santa Cruz, Quintã, Ribeira de Frades $e$ Antuzede, no ano de 1767, III/D, 1, 10, 4, 56.

(8) Saliente-se que nem todas estavam sob a alçada directa dos Crúzios de Coimbra. Travassô, Eirol e Travanca faziam parte dos crúzios de Grijó. Para Travassô ver Pinho Leal. Portugal Antigo e Moderno...., Lisboa, Ed. de Matos Moreira e Companhia, 1873. Para Travanca (S. Martinho) ver o caso concreto de um processo de ordenação sacerdotal de António Borges de 1647. AUC, Ordenações sacerdotais, caixa 32 .

S. Martinho de Travanca era já mencionado num censual do bispado de Coimbra, do século XV, AUC, Cofre, Censual do Cabido da Sé de Coimbra. Estas três freguesias foram doadas pelo bispo de Coimbra D. Bernardo ao mosteiro de Grijó no ano de 1132, como afirma Domingos Moreira em «Freguesias da Diocese do Porto. Elementos onomásticos alti-medievais», Separata do Boletim Cultural da Câmara Municipal do Porto, 1973, pp. 40-41.

( $\left.{ }^{7}\right)$ Portugal, Densidade da População por Freguesias. 1940, carta elaborada por Aristides de Amorim Girão, com a colaboração de Fernanda Lopes Velho. Alfredo Fernandes Martins e Amílcar Augusto Patrício. Este belíssimo mapa ainda pode ser adquir do no Instituto de Estudos Geográficos da Faculdade de Letras de Coimbra. Existe um texto fundamental de Amorim Girão, que explica os procedimentos usados na elaboração do mapa e inventaria muitos dos problemas da sua constituição; ver, Amorim Girão, «Densidade da população por freguesias», Biblos, vol. XXV. 1949, pp. 355-367. 
tornou a ser retomado nos anos 80 pela Comissão Nacional do Ambiente ( $\left.{ }^{8}\right)$.

$\mathrm{Na}$ ausência de representações cartográficas da época, poderia ser tentada uma reconstituição a partir das listas dos lugares de cada paróquia recolhidas em documentos escritos. Localizando esses lugares nos mapas, actuais e traçando o perímetro que os engloba, obter-se-ia a zona correspondente ao território das paróquias antigas. Embora a lista dos lugares seja relativamente fácil de obter (partindo, por exemplo, dos registos paroquiais), localizar esses lugares nos mapas actuais não é tarefa simples, sobretudo quando se opera com 369 paróquias, como é o nosso caso. Por outro lado, os lugares da paróquia só delimitam com precisão um território quando o povoamento é disperso e uniforme. Em zonas de baixa densidade populacional, ou de povoamento concentrado, este tipo de reconstituição tende a criar «ilhas" à volta da sede de freguesia e a deixar zonas de indefinição quanto aos limites das paróquias, tornando altamente problemático o cálculo das suas respectivas áreas. Esta dificuldade representa, no fundo, a indefinição real que muito provavelmente existia quanto aos limites das freguesias em áreas fracamente povoadas.

Um método alternativo consiste em partirmos dos limites das freguesias actuais como base para a reconstituição do território das antigas paróquias. Este processo assenta no facto das actuais freguesias civis terem tido como origem as paróquias eclesiásticas sem nenhuma redefinição explícita de território. Com efeito, quando os cartógrafos actuais necessitaram de traçar esses limites, tiveram que recorrer à memória das populações locais, inquirindo os mais antigos ou aqueles que, pela sua actividade profissional, maior consciência teriam do território $\left({ }^{\circ}\right)$. Ao mesmo tempo, supomos um elevado grau de estabilidade das fronteiras desde as antigas paróquias até às actuais freguesias civis. A comparação do mapa actual com a lista das 369 paróquias do século XVII e XVIII mostra que só 6 não são freguesias actuais. Contudo, existem 23 freguesias actuais que não eram paróquias antigas, tendo sido criadas nos últimos 200 anos por fragmentação de paróquias

(8) Cf. Portugal atlas do ambiente. Notícia explicativa da carta administrativa, elaborada pelo grupo de trabalho do atlas. Secretaria de Estado do Ambiente e Recursos Naturais, Lisboa, 1988.

(9) Ver Amorim Girão, ob. cit., pp. 360-62 e o texto citado na nota anterior. 
existentes. Nestes casos, é fácil fazer a operação inversa reconstituindo as antigas paróquias por adição do território das novas delas desanexadas. No total, só 29 das antigas paróquias da diocese sofreram desanexações ou incorporações (o que corresponde a cerca de $8 \%$ do total das freguesias).

Esta comparação permite supôr que existe uma continuidade muito grande entre as antigas paróquias e as actuais freguesias, ocorrendo as principais mutações por divisão nas zonas onde o crescimento populacional foi mais forte nos últimos dois séculos. $\mathrm{Na}$ esmagadora maioria do território de que nos ocupamos, encontramos uma correspondência directa entre as paróquias antigas e as freguesias astuais. Partimos do princípio que para além dos casos de fragmentação, e os raros casos de paróquias que desapareceram, os limites territoriais das freguesias são, grosseiramente, hoje os mesmos que eram nos séculos XVII e XVIII.

Tal situação justifica-se por nunca ter ocorrido uma redefinição do território das freguesias senão em casos muito localizados. Com efeito a freguesia de hoje, como a paróquia de ontem, têm um estatuto de certo modo atómico na ordenação do território. Encontramos elevado grau de variabilidade em circunscrições de nível superior, como os concelhos, mas é pouco provável que fizesse sentido mudar explicitamente os limites de uma freguesia $\left({ }^{10}\right)$. Sobretudo porque, no Antigo Regime, o território de uma freguesia tinha um significado religioso e económico que lhe conferia uma inércia considerável. Ela encerrava uma população cuja vida religiosa dependia de uma igreja específica que, por sua vez, dependia da actividade produtiva dessa população. Era uma unidade de controle religioso e sobretudo uma unidade económica produtora de bens sobre os quais pesavam várias obrigações. O direito de padroado era um direito precioso pelas implicações económicas que tinha e era defendido muito fortemente sempre que posto em causa. É portanto natural que alterações aos territórios paroquiais fossem difíceis de realizar pacificamente. No mosaico dos direitos de padroado, modificar de modo significativo o limite de uma freguesia, dificilmente não teria como efeito alterar as rendas e recursos das outras

(10) Vejam-se inclusivamente os problemas que ainda hoje isso levanta, de que o caso Crestuma/Lever é um exemplo significativo. 
igrejas envolvidas e dos respectivos padroeiros, além de modificar hábitos de religiosidade provavelmente plurisseculares.

Por muitos argumentos lógicos que se possam acumular, a verdade é que a permanência dos limites das paróquias nas actuais freguesias está por demonstrar inequivocamente, com base em dados empíricos $\left.{ }^{(11}\right)$. O nosso mapa de referência fornece uma imagem que deverá ser bastante próxima da realidade, mas que estará sempre sujeita a desmentidos pontuais e correcções futuras. Os cartogramas derivados do mapa de referência são representados a uma escala suficientemente redutora para tirar significado a variações de pequenas extensões.

No contexto que acabámos de expôr, o primeiro problema a resolver foi o das freguesias que foram criadas depois do século XVIII, mais propriamente depois de 1783, data do último levantamento de visitas pastorais por nós efectuado. Ao olharmos para a carta administrativa actual verificamos que existem hoje algumas freguesias, principalmente ao longo de toda a orla litoral, com especial incidência no eixo Tocha/ /Aveiro, que não existiam no século XVIII. Esta situação obrigou a que primeiramente se tentasse saber a partir de que paróquias antigas foram criadas as freguesias novas. O primeiro passo dado para resolver esta dificuldade foi a

(11) A ideia de que praticamente não houve alterações nos limites das freguesias desde a sua formação até à actualidade pode-se encontrar em Avelino Jesus da Costa. $O$ bispo $D$. Pedro e a organização da diocese de Braga, Coimbra, 1959, vol. I, pp. 79-114; outro estudo que a este respeito pode ser consultado, se bem que tenha um suporte documental mais restrito aue a obra anterior, é a obra de Miguel de Oliveira, As paróquias rurais portuguesas. Sua origem e formação, Lisboa, 1950, pp. 83-92. Sobre a origem dos territórios das freguesias a partir do "desmembramento" das villae romanas, bem como todo o processo de evolução da propriedade administrativa desde a ocupação romana até ao século XII, veja-se a obra fundamental de Alberto Sampaio, "As vilas do Norte de Portugal», Estudos históricos e económicos, Porto, Livraria Chardron, 1923, pp. 170-226. Mais recentemente alguns autores basearam-se também neste pressuposto. Referimo-nos concretamente a Joaquim Romero Magalhães $O$ Algarve económico: 1600-1773, dissertação de doutoramento em História económica e social apresentada à Faculdade de Economia da Universidade de Coimbra, Coimbra, 1984, vol. 2, p. 1091 e a António Manuel Hespanha, As vésperas do Leviathan. Instituições e poder politico, Portugal século XVII, Rio de Mouro. Ed. do autor, 1987, pp. 66-67. 
consulta de dicionários corográficos e enciclopédias $\left({ }^{12}\right)$. Aí, foi possível encontrar as datas precisas do desmembramento de certas freguesias, bem como a referência às freguesias de origem, a partir das quais se criaram as novas $\left({ }^{13}\right)$. Em alguns casos, contudo, as obras referidas não continham informação suficientemente esclarecedora, concretamente no tocante às freguesias de Nariz, Pelariga e Vila Nova de Oliveirinha. Nessa situação, valemo-nos de indicações constantes nas informações paroquiais de 1721 onde se esclarecia que estas freguesias a essa data eram lugares, respectivamente, das freguesias de Requeixo, Pombal e Eixo $\left({ }^{14}\right)$.

(12) Ver Américo Costa, Diccionário Chorographico de Portugal Continental e Insular, Porto, Tipografia Domingos de Oliveira, $1929-49$ e Enciclopédia Luso-Brasileira de Cultura, Lisboa, Editorial Verbo, 1963-86.

(13) Apresenta-se aqui uma lista de todas as freguesias criadas posteriormente a 1783 no espaço que então limitava a diocese de Coimbra, bem como a referência à freguesia a partir da qual foram criadas e data do respectivo desmembramento. Todas estas informações são originárias do Diccionário Corográfico de Portugal e/ou da Enciclopédia Luso-Brasileira de Cultura: Alqueidão, criada a partir do Paião, data da desanexacão não determinada, segundo os registos paroquiais de Paião, em 1854 (data do último registo), Alqueidão ainda fazia parte desta freguesia; Amoreira da Gândara. criada a partir de Sangalhos, data da desanexacão desconhecida. Antes, criada a partir de Ventosa do Bairro em 1964; Barril de Alva, criada a partir de Vila Cova de Sub-Avô em 1924; Bustos, criada a partir da Mamarrosa em 1920; Calvão, criada a partir de Vagos em 1933; Febres, criada a partir de Covões em 1791; Fonte de Angeão, criada a partir de Covão do Lobo em 1965; Gafanha da Boa-Hora, criada a partir de Vagos em 1966; Gafanha da Encarnação, criada a partir de Ilhavo em 1926; Gafanha da Nazaré, criada a partir de Gafanha da Encarnação, data da desanexação nã̉o determinada mas posterior a 1926; Gafanha do Carmo ou dos Caseiros, criada a partir de Gafanha da Encarnação, data da desanexação não determinada mas posterior a 1926; Marinha das Ondas criada a partir de Lavos em 1927; Moura da Serra, a partir dos territórios de Avô, Benfeita, Pomares e Teixeira em 1962; Olivais de Coimbra, criada a partir da antiga freguesia de S. Pedro de Coimbra, em 1865; Ouca, criada a partir de Soza, em 1966; Mealhada, criada a partir da Vacariça em 1947; Ponte de Vagos, criada a partir de Galvão em 1968; S. Bernardo de Aveiro, criada a partir de Vera Cruz de Aveiro em data não determinada; S. Jacinto, criada a partir de Vera Cruz de Aveiro em 1955; Teixeira, criada a partir de Vide em 1824; Torres do Mondego, criada a partir dos Olivais de Coimbra em 1934; Vila Nova, criada a partir de Miranda do Corvo em 1907; Vila Verde, criada a partir do território de S. Julião da Figueira da Foz e das Alhadas em 1790.

(14) Cf. Informações paroquiais de 1721 das freguesias de Eixo, Requeixo e Pombal existentes no AUC. 
Uma vez solucionado este problema, foi possível cartografar a partir da carta administrativa actual, os territórios das antigas freguesias tal como seriam em 1783, antes portanto das desanexações que foram sofrendo desde essa data até hoje.

Se, como vimos, entre 1783 e o presente se criaram algumas freguesias novas, aconteceu também que algumas paróquias existentes antes dessa data desapareceram enquanto freguesias. Nestes casos foi pois necessário averiguar quais as freguesias de que passaram a fazer parte, para a partir daí se poderem representar no mapa utilizando um procedimento que a seu tempo explicaremos. Estavam nesta situação as frepuesias de Doninhas Galizes, Nabainhos, Orada, Pedrulha. Redondos e S. Facundo. Todas elas foram visitadas ao longo dos séculos XVII e XVIII $\left({ }^{15}\right)$.

O processo utilizado para resolver este problema foi idêntico ao descrito para o caso anterior. Uma vez que é possível reconstituir os trajectos que os visitadores efectuavam durante as visitas pastorais, foi relativamente fácil descobrir em que zona ficava cada uma destas freguesias desaparecidas, e a partir daí procurar em dicionários ou enciclopédias as freguesias actuais que lhe estão próximas e ver a lista dos lugares que hoje as compõem $\left({ }^{16}\right)$.

(15) Cf., por exemplo, visita do ano de 1651 dos arcediagados de Penela, Se:a e Vouga, respectivamente A.U.C., III/D,1,4,4,12; III/D,1,4, 2,43 e III/D, $1,4,4,91$.

(16) Foi assim possível descobrir que Doninhas faz hoje parte da freguesia das Talhadas, que Galizes é um lugar da freguesia de Nogueira do Cravo, que Nabainhos é um lugar da freguesia de Melo, que a Pedrulha é hoje parte da freguesia de Santa Cruz de Coimbra, que S. Facundo faz parte de Antuzede. Em relação à anexação de S. Facundo por Antuzede existe no AUC um interessante documento, onde os paroquianos da primeira se insurgem contra a integração da sua paróquia em Antuzede, alegando a melhor situação e importância económica de S. Facundo. Cf., AUC, Caixas de colações (ainda não catalogadas).

Dois casos necessitaram de outra resolução. Referimo-nos a Orada e Redondos. Em relação ao primeiro, foi necessário seguir no terreno o trajecto que os visitadores utilizavam para aí descobrir um pequeno lugar recôndito, habitado actualmente por apenas três ou quatro moradores, onde ainda existe a capela de Nossa Senhora da Orada, próximo de Santiago da Guarda. No segundo caso, valemo-nos das informações do Dr. Rui Cascão, a quem muito agradecemos, cuja dissertação de doutoramento versa sobre a região da Figueira da Foz e que nos esclareceu que Redondos é hoje parte da freguesia de Buarcos. 


\section{A Diocese de Coimbra}

Não se dispõe actualmente de nenhum processo que permita rigorosamente determinar qual era o território destas freguesias antes de serem incorporadas noutras. Assim, a técnica que se utilizou foi a seguinte: partiu-se do princípio que a freguesia antiga e aquela de que passou posteriormente a fazer parte teriam uma densidade populacional aproximada no século XVIII. Como possuímos dados de natureza demográfica para quase todas as freguesias que se encontram nesta situação, foi fácil aplicar uma proporção simples e determinar qual seria a área das freguesias desaparecidas para depois as delimitar (ainda que de forma necessariamente aproximada) no mapa.

Outro caso que foi necessário resolver foi o das freguesias que mantendo o mesmo território mudaram entretanto de nome. Esta situação, também solucionada pelos processos iá referenciados não colocava grandes dificuldades em relação à representação dos limites das freguesias, mas sim em relação à sua identificação $\left.{ }^{(17}\right)$.

Refira-se ainda, a situação em que apesar de haver uma mudança do lugar sede de freguesia isso não correspondeu provavelmente a uma alteração dos limites da freguesia entre 1783 e o tempo presente $\left({ }^{18}\right)$. Como no problema anterior. este não colocava dificuldades ao nível da representação dos limites da freguesia a partir da carta administrativa actual, para além do da identificação das mudanças de sede de freguesia.

Para concluir, falta apenas enunciar o caso de uma freguesia para a qual ainda não foi possível uma solução: Palhaça. Existia já enquanto freguesia autónoma e com este nome antes de 1783 e assim se mantêm. Não se conhece que tivesse algum estatuto especial que lhe conferisse isenção de

(17) Apresenta-se aqui a lista de todas as freguesias que mudaram de nome entre 1783 e o presente indicando-se sempre primeiro o nome antigo e depois o actual separados por uma barra: Bemposta/ /Pinheiro da Bemposta; Cabra/Ribamondego; Castanheira do Pedrogão/ Castanheira de Pêra; Cortiça/S. Martinho da Cortiça; Farinha Podre/S. Pedro de Alva; Oliveirinha/Vila Nova de Oliveirinha; Oliveira do Cunhedo/Oliveira do Mondego; S. Paio de Codeço/S. Paio de Gramaços; Travanca de Farinha Podre/Travanca do Mondego; Vila Nova de Sub-Avô/Vila Cova de Alva; Vila Nova do Casal/Vila Nova de Tázem; Várzea de Góis/Vila Nova do Ceira.

(18) Estão neste lote as freguesias de S. Cosme de Alrote, Cioga do Campo e Reveles que eram os lugares sede de freguesia em 1783 e que posteriormente foram substituídos por Aldeias, S. João do Campo e Abrunheira, respectivamente. 
visita, pelo que não se compreende porque é que nunca aparece nos registos de visitas que possuímos $\left({ }^{19}\right)$.

\section{Descrição geográfica e administrativa da diocese}

A diocese de Coimbra ocupava nos séculos XVII e XVIII um vasto território situado na zona centro do país, englobando regiões que se situam nos actuais distritos de Aveiro, Coimbra, Viseu, Guarda, Leiria e Santarém, numa área aproximada de $7500 \mathrm{Km} 2\left({ }^{20}\right)$.

Em traços largos, diremos que o território diocesano se encaixava nas bacias hidrográficas do Vouga e do Mondego. Era limitado a Oeste pelo Oceano Atlântico $\epsilon$ a Noroeste pelas serras da Arada e Caramulo. Estendia-se do litoral para o interior ao longo da margem esquerda do rio Mondego, para

(19) Palhaça terá pertencido ao concelho de Soza e era o Duque de Lafões que tinha o direito de apresentação do pároco; cf. Américo da Costa, ob. cit.

(20) Em tempos mais remotos a extensão da diocese era superior. Recorde-se que no século XII se estendia a Norte até ao rio Douro e que nessa altura houve conflitos entre o bispo de Coimbra e o do Porto a respeito dos limites das suas dioceses. Sobre o assunto veja-se Miguel de Oliveira, "Os territórios diocesanos», Lusitania Sacra, vol. I. 1956, pp. 29-44). Neste período também para Oriente a diocese era mais extensa, pois ocupava áreas da antiga diocese de Idanha. A partir da altura em que D. Sancho II restabeleceu a cidade da Guarda, como sede da cliocese do mesmo nome, ocorreram conflitos entre os prelados desta cidade e de Coimbra. Esta questão, em que o bispo da Guarda reclamava para si territórios da Covilhã e da Beira, que antigamente faziam parte da diocese de Idanha, levou à ocupação de territórios, sevícias mútuas sobre representantes de uma e outra diocese e só foi sanada definitivamente em 1256. A este respeito veja-se Fortunato de Almeida, História da Igreja em Portugal, Porto, Liv. Civilização, 1968, vol. I. pp. 90-91. Conflitos existiram também com a diocese de Lisboa a propósito de territórios a Sul da diocese de Coimbra. Ver Fortunato de Almeida, ob. cit., vol. I, p. 91. Até 1545, altura em que foi criada a diocese de Leiria, os territórios do bispo de Coimbra alcançavam a cidade do Liz. Cf. Fortunato de Almeida, ob. cit., vol. II, pp. 9-10 e vol. IV, pp. 190-195 (Bula da erecção da diocese de Leiria). Uma ideia da divisão diocesana do território português antes do século XII, bem como a altura da criação e reconquista da diocese de Coimbra pode ser obtida em D. Mansílla. «Geografia Eclesiastica», in Quintin, Aldea Vaquero (dir. de), Diccionario de Historia Eclesiatica de España, Madrid, Instituto Henrique Florez, 1972-75, pp. $984-986$ e $989-993$. 
ocupar toda a Cordilheira Central com as serras da Lousã, Açôr e Estrela, não beneficiando da encosta Sul desta última. A Sul, com algumas alterações de pormenor, a bacia do Liz e o início das elevações das serras de Aires e dos Candeeiros marcavam o seu extremo.

Uma focagem mais aproximada da região, permite-nos verificar que a diocese era limitada por uma série de acidentes geográficos naturais que a separavam das suas vizinhas. Assim a Norte, o rio Antuã, o rio Ul e a serra de Freita marcavam a sua fronteira com a diosese do Porto. Depois para Oriente as serras da Arada. Arestal e do Caramulo, o rio Mau, o rio Dão desde a altura em que se junta ao Miondego até chegar à vila de Santa Comba Dão e o Mondego, separavam-na da diocese de Viseu $\left.{ }^{(21}\right)$. A Cordilheira Central que a diocese ocupava sempre da margem esquerda do Mondego, separava-a das dioceses de, Guarda e Castelo Branco $\left({ }^{22}\right)$. Abaixo da serra da Lousã, novamente os rios marcavam a fronteira da diocese, mais concretamente a ribeira da Pampilhosa e o rio Zêzere. A Sul, confinando com a diocese de Leiria, nem sempre os seus limites fronteiriços tem uma lógica muito clara, já que aqui e ali o território desce até zonas da bacia do Liz. De qualquer forma, podemos dizer que os rios Arunca, ribeira de Santiais, o rio Nabão e a ribeira da Murta, sensivelmente o território que separa as serras do Sicó (ainda na diocese) e as serras de Aires e dos Candeeiros, marcavam aqui a fronteira.

A diocese ficava pois na sua quase totalidade (exceptuando o litoral a sul do vale do Mondego) num território com características muito próprias na paisagem nacional, a região a que Orlando Ribeiro chamou o Norte Atlântico $\left({ }^{23}\right)$. Terras de chuva abundante e de orografia variada (bacias do Vouga e do Mondego), onde a influência dos ventos oceânicos penetra fundo graças ao Mondego, é uma das zonas mais arborizadas de Portugal (especialmente o pinheiro bravo no litoral e o carvalho no interior). É também onde se encon-

(21) Para uma descricão mais detalhada do Baixo Mondego ver Maria Helena da Cruz Coelho, O Baixo Mondego nos finais da Idade Média, Coimbra, Faculdade de Letras, 1983. vol. I, pp. 1-5.

(122) A diocese de Castelo Branco só confinou com a de Coimbra a partir de 1770 . data da sua criação. Antes desta data, era a diocese da Guarda que administrava os territórios que Castelo Branco veio a ocupar. Cf. Fortunato de Almeida, História da Igreja...., ob. cit., vol. III, p. 10 .

(23) Cf. o belíssimo trabalho de Orlando Ribeiro, Portugal o Mectiterrâneo e o Atlântico, Lisboa, Sá da Costa, 1986, especialmente pp. 145-149, que nesta pequena descrição acompanharemos de perto. 
tram das mais altas densidades populacionais (o vale do Vouga é nos territórios diocesanos o exemplo mais significativo) e circunscrições administrativas relativamente pequenas, constituídas quase sempre por uma "poeira de lugares" $\left({ }^{24}\right)$.

As regiões da Beira Alta e a Cordilheira Central, se bem que com analogias com as regiões do Noroeste, têm contudo especificidades que as separam deste. Aqui a população é menos densa e o povoamento mais concentrado, as planícies cedem lugar a planaltos, serras escarpadas e vales cavados e com a altitude as chuvas caem frequentemente sob a forma de neve, tornando o clima mais rigoroso e a vida mais severa.

A sul do vale do Mondego a situação é diversa. Os terrenos calcários e secos abundam, a estiagem é mais prolongada, o carvalho alvarinho é substituído pelo carvalho português e a população vai-se tornando cada vez menos volumosa.

Administrativamente, a diocese acompanhava muito de perto as particularidades geográficas que temos vindo a desenhar, ao dividir-se em 4 partes. Em primeiro lugar temos a cidade de Coimbra, com as suas 8 paróquias (exceptuando S. João de Santa Cruz) que se autonomiza fundamentalmente devido ao seu peso administrativo cultural político e económico. Depois, três arcediagados dividem entre si o resto do território diocesano. $\mathrm{O}$ arcediagado de Vouga, situado a Norte do rio Mondego, com 146 varóquias. o arcediagado de Penela, a Sul do Mondego e a Oeste do rio Ceira (sensivelmente) com 92 naróquias, e finalmente o arcediagado de Seia correspondendo à área a Sul do Mondego e a Este do Ceira, com 123 naróquias. No total, o território da diocese era composto por 369 paróquias.

Como se verifica, pelas regiões que ocupavam, estes arcediagados tinham certas características geográficas próprias. Vouga fica no Noroeste Atlântico, Seia no interior Atlântico e Penela corresponde a uma zona de transição entre o Atlântico e o Mediterrâneo que sucintamente acima descrevemos.

Esclareça-se, finalmente que em 1774 a diocese foi significativamente amputada em alguns territórios dos arcediagados do Vouga e de Seia. Assim, pelo breve Militantis Ecclesia do Papa Clemente XIV, publicado em 12 de Abril de 1774, foi criada a diocese de Aveiro à custa de freguesias da diocese, como o mapa $n .^{\circ} 1$ mostra. 0 mesmo breve serviu para des-

(24) Cf. Amorim Girão, ob. cit., p. 366. 


\section{A Diocese de Coimbra}

membrar da diocese algumas paróquias nos limites do arcediagado de Seia, que passaram para a diocese da Guarda $\left({ }^{25}\right)$.

\section{A população da diocese de Coimbra no século XVIII}

Uma análise geográfica da diocese de Coimbra não poderia prescindir de uma tentativa de estimar as características da distribuição da população no seu território. A ocupação humana do território é um factor fundamental para a determinação das suas características regionais internas, bem como é indispensável para a interpretação de outros fenómenos que só são analisáveis quando formulados em função da população (isto é, per capita).

Neste sentido interessa-nos conhecer não só os valores totais da população da diocese, e a sua evolução ao longo do tempo, mas também aproximar a sua distribuição dentro da diocese, paróquia a paróquia.

A quantidade e qualidade da informação que se pode recolher nas fontes disponíveis está muito aquém do que seria necessário para formar uma visão segura da evolução da população das 369 paróquias da diocese de Coimbra no século XVIII. Teremos que nos contentar com valores aproximados que, no presente trabalho, assumirão a forma de um valor representativo da população média de cada paróquia para o período de tempo em que temos maior concentração de fontes, e uma taxa de crescimento médio anual para cada uma das paróquias, calculada a partir de duas fontes de confiança, o mais afastadas possível no tempo. Consideramos os valores obtidos aceitáveis desde que, por um lado, se consigam delimitar as margens de erro em que incorremos e, por outro, que a interpretação dos resultados não ceda à tentação de jogar com preciosismos quantitativos cujo significado se invalidaria pelo carácter aproximativo do método usado.

O método pelo qual chegamos à imagem da distribuição da população na diocese será exposto a seguir. Em primeiro lugar apresentaremos as fontes disponíveis e seguidamente o método pelo qual determinámos o grau de confiança que cada uma delas merece. Depois indicaremos os pressupostos e tipo de cálculos utilizados para chegar aos valores representativos da população de cada paróquia.

(25) Este breve está publicado em Fortunato de Almeida, ob. cit., vol. IV, pp. 247-252. 


\subsection{Fontes utilizadas}

Existem várias contagens de fogos e almas por paróquias para a diocese de Coimbra no século XVIII $\left({ }^{26}\right)$.

Cronologicamente a primeira é a Corografia Portugueza do P. Carvalho da Costa $\left({ }^{27}\right)$. Das 369 paróquias da diocese, encontramos na Corografia contagens de vizinhos (entenda-se fogos) para 196. A fonte de Costa não é clara, afirmando o autor que "um dos nossos principais intentos foi não repetir o que outros já referiram senão o essencial para o nosso contexto, acrescentando-lhe todas as notícias que laboriosamente recolhemos. Com um largo giro que fizemos por todo este reino, observamos a arrumação de suas povoações, os distanciamentos umas das outras, servindo-nos muito para este fim o estudo que sempre cultivámos das matemáticas. Os olhos nos informaram do estado presente de tudo o que se descreve» $\left({ }^{28}\right)$. Parece-nos improvável que todos os dados tenham sido recolhidos in loco. Como veremos, é possível demonstrar que, a este respeito, a informação da Corografia é indirecta e pouco fiável.

Temos depois os livros de registo dos róis de confessados da diocese, onde eram registadas as entregas dos róis de confessados anuais pelos párocos ao provisor ou vigário geral do bispado, conforme estipulado nas constituições do bispado $\left({ }^{29}\right)$. Existem no Arquivo da Universidade de Coimbra 5 destes livros, cobrindo o período entre 1709 e 1839 (faltam

(26) Ver Armando Carneiro da Silva, «Evolução populacional Coimbrã", Arquivo Coimbrão, Boletim da Biblioteca Municipal, vol. XXIII, Coimbra, 1968, pp. 193-305, e em especial 209-250 para a época que nos interessa. As fontes utilizadas por Carneiro da Silva para o século XVIII, acrescentamos aqui os livros de registo de róis de confessados e as informações paroquiais de 1763, enquanto que não utilizamos a Descripçam Corographica do Reyno de Portugal, que contem uma exacta relaçam de suas provincias...., de António de Oliveira Freire, Lisboa. 1739, por ser demonstrável que a informação demográfica aí contida é copiada da Geografia Histórica, de Caetano de Lima (recorrendo à Corografia de A. Costa para os casos em que a Geografia é omissa).

${ }^{(27)}$ António Carvalho da Costa, Corografia Portugueza e descripçam topografica do famoso reyno de Portugal com as noticias das fundaçoes das cidades, villas, \& lugares...., Lisboa, Of. de Valentim da Costa Deslandes, 1706-1712, 3 vols.

(28) Cf. António Carvalho da Costa, ob. cit., prólogo.

${ }^{(29)}$ Ver Constituiçoens Synodaes do Bispado de Coimbra, feitas por D. Afonso de Castelo Branco em 1591, mas que vigoraram nos séculos XVII e XVIII. Coimbra, Real Colégio das Artes da Companhia de Jesus, 1731, título IV, Constituição, 1, parágrafos 1 e 7, pp. 13 e 16-17. 
os anos de 1764 a 1779 e de 1798 a 1831) $\left({ }^{30}\right)$. Em geral, as entradas referem apenas a data do registo, a paróquia cujo rol se registava, o nome do pároco e o nome dos revéis, quando os há $\left({ }^{31}\right)$. Entre 1709 e 1713, o registo de algumas paróquias inclui o total do rol, quer fornecendo o total de fogos, ou o total de almas, ou ambas as coisas. Por vezes o registo descrimina o número de indivíduos maiores ou menores (confessados e comungados), e, em alguns raros casos, distingue os ausentes e clérigos. No conjunto, os registos de róis disponíveis fornecem-nos totais de fogos para 79 paróquias e de almas para 185 , entre 1709 e $1712\left({ }^{32}\right)$.

Posteriormente, as informações paroquiais de 1721, cujos originais se conservam no Arquivo da Universidade de Coimbra, fornecem-nos contagens de população para 328 paróquias, indicando por vezes o número de fogos (198), outras vezes o número de almas (253) e, nalguns casos, descriminando as almas de comunhão e de confissão e os quantitativos de ambos os sexos. A fonte de informação são os próprios párocos ao responderem ao ítem 3 dum formulário onde se declara: "Que número de fregueses tem a freguesia, que mosteiros, se há casa de misericórdia, hospitais ou recolhimentos, e em que ano foram fundados e por quem» $\left({ }^{33}\right)$.

A Geografia Histórica de todos os Estados soberanos da Europa de Luíz Caetano de Lima, constitui a quarta fonte examinada $\left({ }^{34}\right)$. Inclui no fim uma "Lista dos fogos, e almas,

(30) AUC, III/D,1,5,2,116 a 120.

(31) $O$ que torna esta fonte interessante para reconstituições de comunidades históricas.

$\left.{ }^{(32}\right)$ Na nossa opinião, estes valores deveriam constar dos próprios róis, naquelas paróquias em que o pároco tinha o hábito de contar e registar os totais. O escrivão limitava-se a copiá-los para o livro de registo. Por alguma razão que não pudemos apurar este tipo de informação desaparece de todo a partir de 1713. O mesmo tipo de fonte, embora com uma qualidade e consistência ao que parece muito superior, foi utilizado por Romero Magalhães, ob. cit., ver vol. 2, p. 1066.

(33) Ver AUC, informações paroquiais de 1721. Ver também, Maria José Mexia Bigotte Chorão, «Inquéritos promovidos pela coroa no século XVIII», Revista de História Económica e Social, Setembro-Dezembro, 1987, n. 21, pp. 93-119 e A.G. da Rocha Madahil. «Novas fontes da história local portuguesa. As informações paroquiais da diocese de Coimbra pedidas pela Academia Real da História em 1721", Biblos, vol. X, 1934, pp. 591-607.

(34) Luís Caetano de Lima, Geografia histórica de todos os estados soberanos da Europa, Lisboa, Of. de José António da Sylva, impressor da Academia Real, 1734-1736, 2 vols. 
que ha nas terras de Portugal....", comunicada ao autor pelo Marquês de Abrantes em 1732. É a fonte que cobre maior quantidade de paróquias com contagens simultâneas de fogos e almas (305), mas apresenta problemas de datação ${ }^{\left({ }^{5}\right)}$. Não pudemos determinar as fontes da Lista, mas, como veremos, os valores aí apresentados são muito semelhantes aos de informações prestadas pelos párocos, especialmente as de 1721 .

o Dicionário Geográfico ou notícia histórica de todas as cidades, vilas e lugares... do P. Luís Cardoso é uma obra incompleta (incluindo só topónimos até à letra C) que contudo ainda possui informação do número de fogos de 99 paróquias da diocese de Coimbra $\left({ }^{36}\right)$. A obra foi baseada nas respostas dos párocos a um inquérito bastante complexo. o questionário deve ter circulado no início dos anos $30 \mathrm{ou}$ talvez antes $\left({ }^{37}\right)$. As respostas perderam-se durante o terramoto de 1755. impedindo o acabamento da obra. Após 1755, o mesmo padre Luís Cardoso organizou novo inquérito, que juntou a necessidade de se conhecer o efeito do terramoto no país ao desejo de completar a obra interrompida, dando origem às informações paroquiais de 1758 .

As informações paroquiais de 1758 são as respostas dos párocos ao questionário organizado pelo padre Luís Cardoso após o terramoto. Conservam-se hoje no Arquivo Nacional da Torre do Tombo. Nestas informações encontramos uma grande variabilidade na estrutura das respostas. Alguns párocos discriminam a população de cada lugar da paróquia, outros fornecem somente o total, outros ainda referem apenas a população do lugar da sede da paróquia. Esta variação resulta do carácter ambíguo da formulação do inquérito. No conjunto de informações que consultámos recolhemos 109 contagens de fogos e 99 de almas $\left({ }^{38}\right)$.

(35) Ver Romero Magalhães, ob. cit., vol. 2, pp. 1072-1080, onde se demonstra, de modo difícil de refutar, que no respeitante ao Algarve a Lista seria de 1705 . Voltaremos mais adiante ao problema da datação dos dados demográficos de Caetano de Lima.

(36) Luís Cardoso, Dicionário geográfico ou notícia histórica de todas as cidades, vilas e lugares, Lisboa, Régia officina Sylviana e da Academia Real, 1747-51, 2 vols.

${ }^{(37)}$ Ver Maria José Mexia Bigote Chorão, ob. cit., pp. 96-101.

(38). Consultámos as informações de 1758 através de um micro-filme existente no Centro de História da Sociedade e da Cultura da Faculdade de Letras de Coimbra. Infelizmente, o referido micro-filme não incluía as informações respeitantes às comarcas da Guarda e da Esgueira que englobavam algumas freguesias da diocese de Coimbra. 


\section{A Diocese de Coimbra}

Nem todas as paróquias responderam ao inquérito de 1758. Por motivos ainda não muito claros. o padre Luís Cardoso decidiu publicar, sob o pseudónimo de Paulo Dias Niza, uma obra muito menos ambiciosa que o Dicionário Geográfico, utilizando contudo as respostas ao inquérito de 1758 -O Portugal Sacro-Profano ( $\left.{ }^{39}\right)$. Em 1763 foi enviado aos párocos de algumas paróquias da diocese de Coimbra um questionário cujas respostas serviriam para "huma geografia que se pretende fazer" $\left({ }^{40}\right)$. Temos as respostas de 89 paróquias (fornecendo somente contagens de fogos) ${ }^{\left({ }^{41}\right)}$. Este inquérito está indiscutivelmente ligado à elaboração do Portugal Sacro-Profano. Não só as respostas dizem respeito a freguesias para as quais não existiam informações em 1758, não só os pontos do inquérito são os mesmos das entradas da obra publicada, como a informação apresentada no Portugal Sacro-Profano e nas respostas a este inquérito de 1763 é rigorosamente a mesma $\left.{ }^{(42}\right)$.

O Portugal Sacro-Profano, de Paulo Dias Niza (aliás, padre Luís Cardoso), inclui dados recolhidos nas informações de 1758 e nas de 1763 , fornecendo os quantitativos populacionais das paróquias em fogos. Recolhemos aqui os valores de 350 das 369 paróquias da diocese.

Finalmente, foi usado o censo promovido por Pina Manique já no fim do século e publicado por J. Veríssimo Serrão ${ }^{\left({ }^{4}\right)}$. Censo de intuitos militares, fornece a população em fogos para 349 das freguesias da diocese. A origem da informação terão sido provavelmente os párocos, mas a organização do censo em três níveis, 1) comarcas, 2) cidades, vilas e terras, 3) paróquias, introduz um factor de confusão. Com efeito, algumas paróquias incluíam lugares que pertenciam a

(39) Cf. Paulo Dias de Niza. Portugal sacro-profano ou catálogo de todas as freguesias do reino de Portugal e Algarves: das igrejas com seus oragos...., Lisboa, Of. de Miguel Manescal da Costa, impressor do Santo Offício, 1767-68.

(40) Segundo o formulário do questionário, que reproduzimos em anexo (ver anexo n. 2 ).

(41) Arquivo da Universidade de Coimbra, III/D,1,4,3,75.

(42) Só em dois casos, Mata Mourisca e Orada, encontrámos informações de 1758 e 1763 . Existem 7 casos de ligeiras variações entre a obra de Niza e as informações de 1763, certamente devidos a erros de leitura ou de impressão.

(4:3) Joaquim Veríssimo Serrão, A população de Portugal em 1798. O censo de Pina Manique, Paris, Fundação Calouste Gulbenkian, Centro Cultural de Paris, 1970. 
termos diferentes e por isso aparecem repetidas nas «tábuas» dos censos, apresentando somente a população da parte da freguesia que pertencia ao termo em questão. É assim necessário somar as várias ocorrências para se ter a população total da paróquia. Este fenómeno é particularmente importante na zona do Vouga, e, evidentemente, aumenta a probabilidade de erro dos resultados, organizados por circunscrições que não correspondem às unidades paroquiais simples, para as quais os párocos possuíam informação. Não utilizámos este censo para o cálculo da população de cada paróquia, uma vez que não queríamos obter um valor influenciado por uma contagem tão tardia. A sua utilização principal foi o cálculo das taxas de crescimento médio ao longo do século, uma vez que comparando as informações de $1721 \mathrm{com}$ os dados de 1798 tínhamos, ao mesmo tempo, uma grande cobertura geográfica e uma considerável distância no tempo $\left({ }^{44}\right)$. Procurávamos dessa maneira detectar a tendência a longo prazo, com as limitações inerentes aos problemas específicos dos dados de 1798 que acabámos de referir.

\subsection{Método utilizado}

Como acabamos de constatar, o conjunto de informações demográficas de que dispomos apresenta-nos duas dificuldades principais. Em primeiro lugar, não possuímos informações completas para todas as paróquias da diocese: antes temos informações parcelares para conjuntos diferentes de paróquias que só parcialmente se sobrepõem em diferentes momentos no tempo. Em segundo lugar essas informações são de origem diversa e foram recolhidas com objectivos variados. Estas dificuldades implicam que é necessário, antes do mais, testar o grau de confiança que nos merece cada fonte. Em segundo lugar, que, se pretendemos uma visão geral da diocese, teremos que extrapolar valores de fontes diversas, correspondendo a momentos diferentes no tempo, e de controlar o tipo de erros em que incorremos ao fazê-lo.

Numa primeira aproximação ao problema da validade das várias fontes, temos que encarar o facto de não possuir-

(44) Utilizámos 1721 em vez do registo de róis, apesar de anterior, porque esta última fonte inclui informação sobre um número de paróquias muito mais pequeno. 


\section{A Diocese de Coimbra}

mos, a priori, uma fonte "segura" a partir da qual as outras, por comparação. possam ser avaliadas. Dum ponto de vista qualitativo, podemos aceitar que a fonte principal para o conhecimento da população das paróquias era o rol dos confessados elaborado anualmente pelo pároco e que continha os habitantes da freguesia com mais de 7 anos. 0 pároco era o principal informador sobre os aspectos populacionais da paróquia de que era responsável. Eram os párocos os últimos destinatários dos inquéritos sobre poulação, mesmo quando originados pela coroa ${ }^{\left({ }^{45}\right)}$. Elaborando anualmente o rol, respondendo a frequentes inquéritos, é natural que o pároco conhecesse com razoável precisão o número dos seus paroquianos $\left({ }^{48}\right)$. Quando interrogados explicitamente sobre 0 número de fogos ou de almas da sua paróquia, os párocos deveriam fornecer uma imagem bastante correcta (com os inevitáveis erros de contagem ou de registo e cópia da informação prestada). Neste sentido, o registo de róis de confessados e as informações de 1721, 1758 e 1763, por estarem muito próximas da origem da informação, deverão ser mais seguras. Por outro lado, as várias "corografias» introduzem um inevitável factor de mediação que é difícil de controlar hoje.

Esta questão pode ser aproximada de um ponto de vista estatístico. A informação recolhida para as várias paróquias nas diversas fontes constituiu uma oportunidade de testar, em termos estatisticamente significativos, a verosimilhança dos valores apresentados. Com efeito, se fontes diversas apresentam elevados coeficientes de correlação, e sendo demonstrável que não se copiam mutuamente, é necessário concluir que o que as liga é a referência comum à mesma realidade populacional.

Partindo deste princípio calculámos os coeficientes de correlação entre os valores apresentados para as paróquias da diocese pelas várias fontes acima descritas e, ao mesmo tempo, a variação no total de população de fonte para fonte. 0 conjunto de paróquias utilizado em cada comparação varia de caso para caso, uma vez que as fontes não se sobrepõe exactamente (ver quadro I).

(45) Ver Maria José Mexia Bigotte Chorão, ob. cit., onde se descreve, documentadamente. o processo através do qual um inquérito de iniciativa régia chegava até aos párocos.

(46) Ver Romero Magalhães, ob. cit., vol. 2, p. 1968. 
Número de contagens de fogos em comum e coeficientes de correlação entre as várias fontes

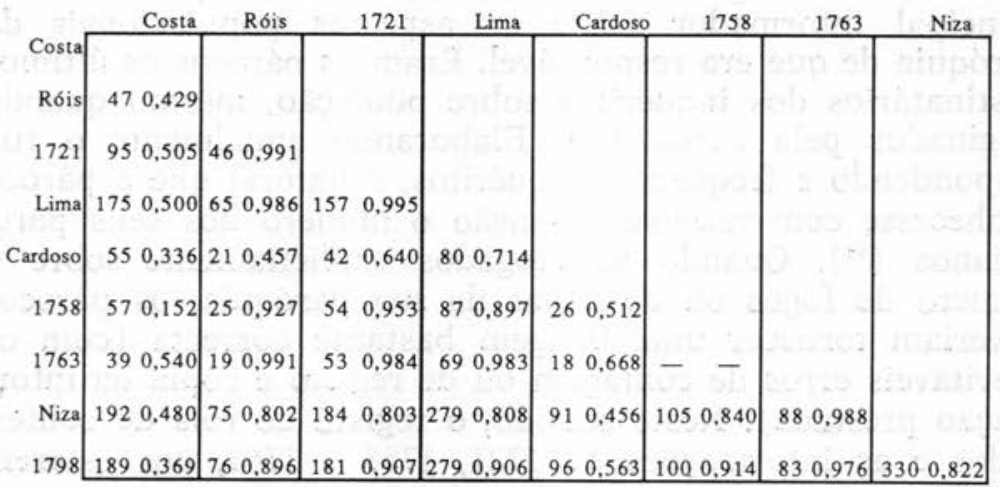

A primeira conclusão a que se chega é a de que existe um grupo de fontes altamente correlacionadas entre si: o registo de róis de confessados, as informações de 1721, 1758 e 1763 e a Geografia de Caetano de Lima (a única fonte impressa que passa com êxito este teste). 0 censo de 1798 tem ainda altos coeficientes de correlação com este grupo, sobretudo com as fontes cronologicamente mais próximas $(0.976$ entre 1798 e 1763). Consideramos estas as fontes «seguras» $\left({ }^{47}\right)$. Inversamente a Corografia de A. Costa, o Dicionário Geográfico e o Portugal Sacro-Profano têm fracas correlações entre si e com o grupo anterior. Os gráficos 1 e 2 exemplificam

(47) O valor dos coeficientes de correlação, $m$ como critério de validação de um conjunto de fontes, funciona mais positivamente do que negativamente. Queremos com isto dizer que se duas fontes são altamente correlacionadas isso tem um valor de validação recíproca considerável. Mas o inverso é menos verdade. Situações de rápida mutação da realidade demográfica podem provocar, em teoria, que duas fontes perfeitamente fiáveis forneçam valores que realmente eram diferentes, apresentando coeficientes de correlação relativamente baixos. Os limites exactos que esse fenómeno pode assumir são contudo difíceis de quantificar sem recorrer a situações concretas documentadas ou simulações baseadas em modelos demográficos. Contudo, fique claro que não entendemos que baixos coeficientes de correlação, só por si, indiquem a presença de fontes inutilizáveis. 


\section{A Diocese de Coimbra}

as diferenças que se obtêm ao comparar deste modo as fontes, ao mostrar a correlação entre os dados colhidos no livro de registo dos róis de confessados, por um lado, e a Corografia de A. Costa e a Geografia Histórica de Caetano de Lima, por outro. Conclui-se da sua análise que o registo de róis e a Geografia têm um referente comum, a população diocesana, e confirmam-se mutuamente, enquanto que entre o registo de róis e a Corografia não existe qualquer espécie de correlação estatística, o que deixa supôr precisamente o contrário).

Gráfico 1: Correlação entre a Geografia de C.Lima e o registo de róis.

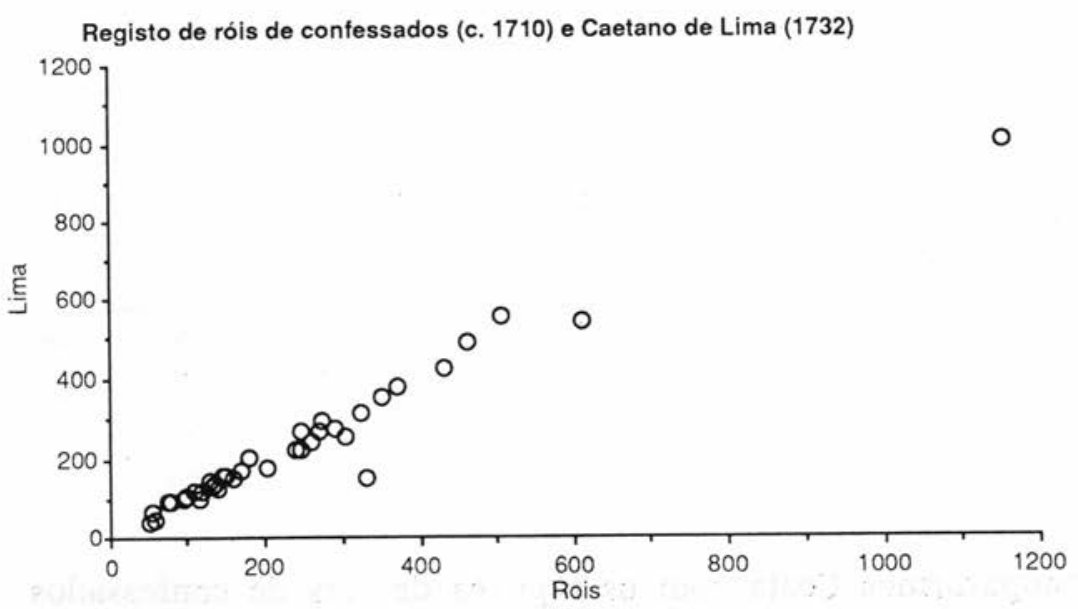

Alguns aspectos adicionais são possíveis de concluir desta comparação. A Corografia de A. Costa mostra os valores mais baixos de correlação com todas as outras fontes. $\mathrm{O}$ gráfico 2 é elucidativo. Esse afastamento em relação às outras fontes, parecendo por vezes completamente aleatório, assume, em termos globais, uma subestimação considerável. Quando somamos os valores dados por Costa para um conjunto de paróquias e o comparamos com os valores dados para o mesmo conjunto por outras fontes, parece notório que Costa fornece valores que, em geral, pecam por defeito. Assim se 


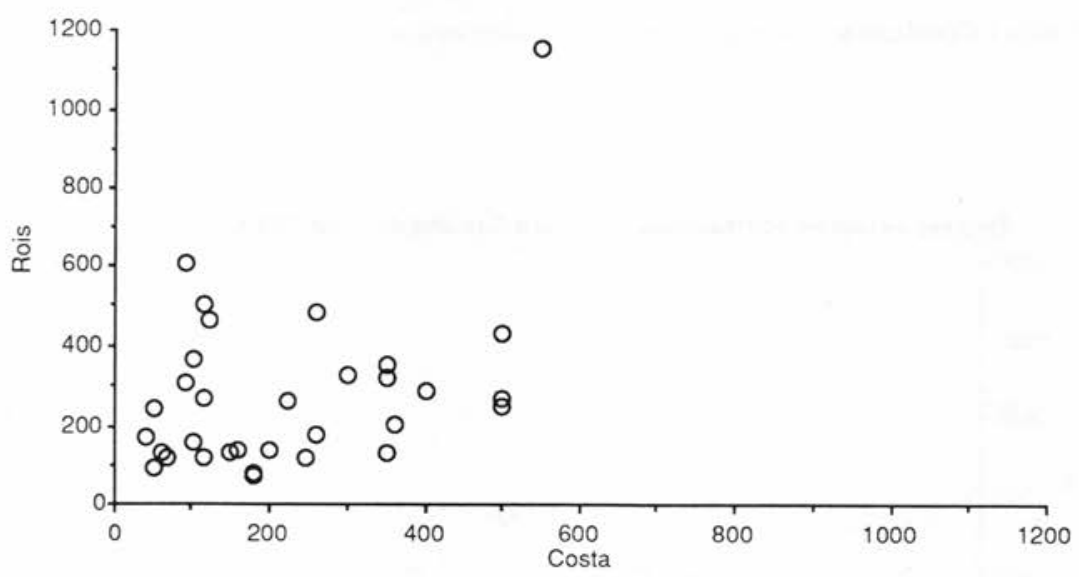

compararmos Costa com os registos de róis de confessados vemos que a total de fogos é $25 \%$ superior nestes do que naquele. Se atendermos a que os valores de Costa seriam do início do século XVIII e que o valor dos registos de róis se situa entre 1709 e 1712 , vemos que na verdade os totais obtidos na Corografia subestimam claramente a população. Podemos concluir que os valores de Costa estão longe de ser em primeira mão. Aliás esses valores denotam pelo menos uma característica típica das aproximações grosseiras, que é a frequência com que ocorrem valores divisíveis por 100 ou $50(100,150,200,250)$. Esta distorção é notória nos valores dados pela Corografia enquanto que em outras fontes, como por exemplo na Geografia de Caetano de Lima, o fenómeno é muito menos notório (ver gráficos 3 e 4). 


\section{A Diocese de Coimbra}

Gráfico 3: distribuição das paróquias por número de fogos na Corografia de A.Costa

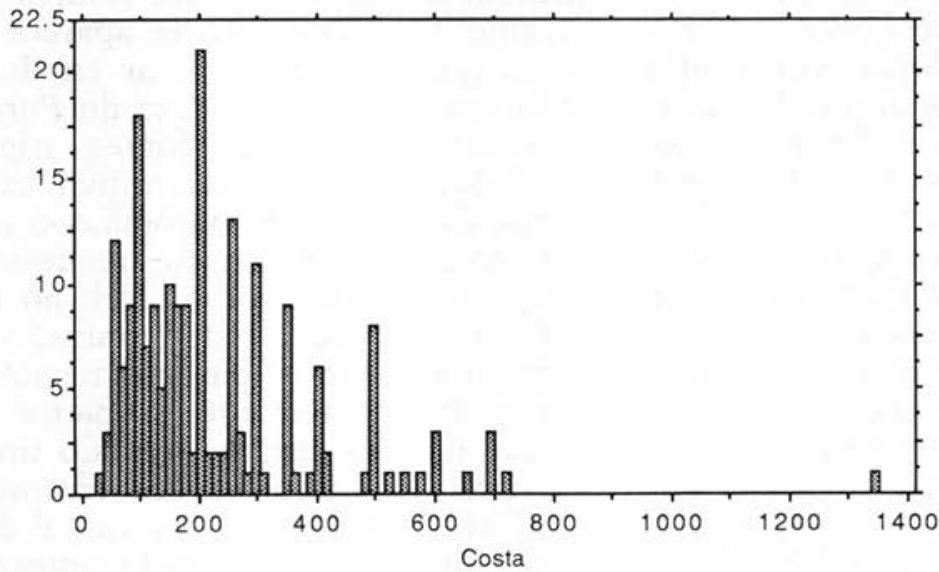

Gráfico 4: distribuição das paróquias por número de fogos na Geografia de C.Lima

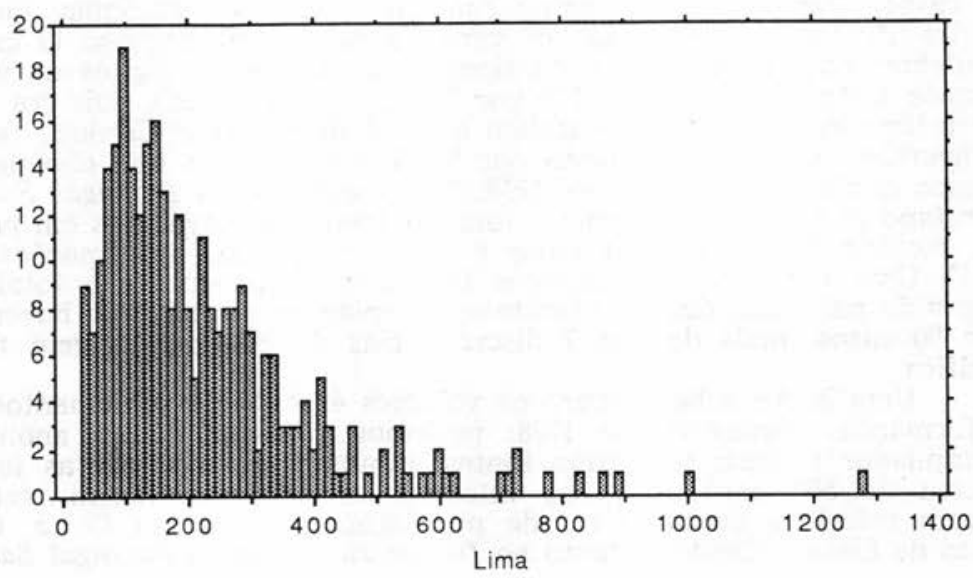


Um tipo de distorção diferente ocorre nas duas obras do padre Luís Cardoso. Tanto o Dicionário Geográfico como o Portugal Sacro-Profano apresentam um padrão muito característico nas correlações com as outras fontes "seguras»: parte das paróquias aparecem nestas obras com valores plausíveis, mas, ao mesmo tempo, uma outra parte aparece com valores muito inferiores ao que seria de esperar em função das outras fontes concordantes entre si. No caso do Portugal Sacro-Profano, como podemos examinar as fontes originais (os inquéritos de 1758 e 1763), é possível determinar exactamente a causa do fenómeno. Em parte das paróquias o padre Luís Cardoso publica a população da sede da freguesia em vez da população total da freguesia e é impossível, no texto da obra, distinguir as duas situações. Esta confusão, em parte, é devido ao modo variado como os párocos respondem ao inquérito de 1758 , mas, frequentemente, o padre Luís Cardoso fornece a população da sede mesmo quando tinha o total da população disponível nas informações paroquiais. Houve, seguramente, uma flutuação de critérios. que é difícil de entender $\left({ }^{48}\right)$. De qualquer modo, a conclusão incontornável

(48) Podemos dar uma ideia mais concreta de como as informacões de 1758 foram utilizadas na elaboração do Portugal Sacro-Profano. Fizemos uma comparacão detalhada para 88 paróquias da comarca de Coimbra. Nessas paróquias, os párocos forneceram quer o total de fogos da paróquia. quer a lista dos vários lugares e respectivos vizinhos, quer ainda ambas as coisas. Em vez de utilizar sempre os números que mais se aproximassem do total da população da paróquia, o Portugal Sacro-Profano ora utiliza o número de fogos da sede quando tinha igualmente o total (10 casos), ora faz o contrário, dando o total da paróquia e ignorando a informação sobre a sede (6 casos). Em três casos tentou calcular o total da paróquia, que o padre não fornecia somando os vários lugares. Acrescente-se 12 casos evidentes de erro de leitura ou tipográfico (trocas de dígitos ou algarismos saltados: 72 por 62,220 por 320,37 por 137 , etc.), dois em que as informações de 1758 forneciam o total de almas e Cardoso faz a conversão, em fogos dividindo por 5,5 , e outros 8 em que não detectámos qualquer relação com 1758. Em conclusão, o Portugal Sacro-Profano só fornece realmente o total de fogos das paróquias em perto de metade dos casos. Diferente é a utilização das informações de 1763. Uma vez que aí os parocos fornecem simplesmente o total de fogos da paróquia, Cardoso limita-se a copiar esse valor, não havendo, em 90 casos, mais do que 7 discrepâncias de provável origem tipográfica.

Uma breve achega sobre os volumes 42 e 43 de suplementos às informações paroquiais de 1758: pudemos verificar que o anónimo compilador utilizou sobretudo fontes imoressas para suprir as faltas (cerca de 500 paróquias) nas informações originais. Assim, vemos serem referidos quantitativos de população colhidos em Costa. Caetano de Lima e Cardoso (tanto no Dicionário como no Portugal Śacro- 


\section{A Diocese de Coimbra}

é que ambas as obras do padre Luís Cardoso misturam lugares sedes de paróquia com as paróquias propriamente ditas, sem que seja possível ao leitor distinguir os dois casos. Todos os agregados globais feitos com base nestas obras darão necessariamente valores que erram por defeito.

A Geografia Histórica de Caetano de Lima põe um problema adicional de difícil resolução: serão realmente de 1732 os dados que publica? Como afirmámos em cima, a obra de Caetano de Lima, publicada em 1734-1736, revela elevados índices de concordância com as outras fontes directas $\left({ }^{49}\right)$. Mas ao passarmos das correlações ao exame mais atento dos totais que apresenta vemos que estes são relativamente baixos. Num conjunto de 157 paróquias para as quais temos contagens de fogos em 1721 e na Geografia de Lima, o total é praticamente o mesmo, passando de 39560 para 39546 . Se compararmos almas, em 199 paróquias, o total passa de 159268 para 157905 , uma diminuição que não chega a $1 \%$. As duas fontes são visivelmente muito próximas: têm um elevadíssimo coeficiente de correlação $(0.995)$ e em 11 paróquias o número de fogos é exactamente igual ${ }^{\left({ }^{50}\right)}$. Romero Magalhães pôs fortemente em causa, para o Algarve, a data de 1732 para esta fonte. Confrontado com o mesmo problema em relação à interpretação dos dados populacionais fornecidos por C. Lima (plausibilidade dos dados em geral mas valores demasiado baixos), e possuindo um manancial de fontes adicionais muito extenso, que lhe permitiu uma comparação mais precisa, este autor demonstrou que os valores da Geografia, no caso do Algarve, devem corresponder ao ano de 1705 e não de $1732\left({ }^{51}\right)$. No nosso caso a questão não é tão clara. A comparação efectuada sugere uma vizinhança muito próxima a 1721. Mas será

-Profano). Por vezes detectam-se curiosas manipulações aritméticas dos dados: na tentativa de dar a estimativa mais recente da população, o autor dos suplementos utilizou o número de fogos do Portugal Sacro-Profano e calculou as almas correspondentes fazendo uma regra de três simples com os valores fornecidos por Caetano de Lima.

(49) Coeficientes de correlação de 0,986 com o registo de róis de confessados, 0,995 com 1721. 0,897 com 1758, 0,983 com 1763 .

(50) E. contudo, evidente que uma não copia a outra, porque ao nível de cada paróquia os valores não são iguais (à excepção dos 11 casos de contagens de fogos idênticas) e Lima fornece sempre almas e fogos, enquanto em 1721 as respostas variam muito nesse aspecto.

(51) Ver nota 10. O autor teve o cuidado de deixar claro que a data de 1705 não era generalizável para fora do Algarve, adiantando que os valores da Beira seguramente que o não eram, sem acrescentar pormenores. 
de excluir que os valores sejam realmente de 1732, e que tenha havido um ligeiro decréscimo de população nos 10 anos que medeiam as informações paroquiais de 1721 da Lista do Marquês de Abrantes? Pensamos que, no que diz respeito à zona do território da diocese de Coimbra, o problema deve permanecer em aberto.

Seria de abandonar assim os dados de Caetano de Lima? Pela plausibilidade dos valores e pela ampla cobertura geográfica, Caetano de Lima é uma fonte preciosa. Ao nível a que estamos a trabalhar consideramos que podíamos utilizar esses valores na tentativa de aproximar a distribuição populacional na diocese, mantendo presente que incorremos num erro possível de 10 anos na utilização que fazemos da fonte. Que tipo de distorção poderá essa diferença implicar nos nossos dados? Esta questão leva-nos à necessidade de conhecer os ritmos de crescimento (ou diminuição) da população da diocese de Coimbra ao longo do século XVIII. não só em termos globais mas também nas suas variantes regionais. Como veremos, as tendências globais, a longo prazo, são tão lentas que minimizam os riscos deste tipo. Para abordar esse problema necessitamos antes de examinar as possibilidades que nos dão as fontes «seguras».

Abandonando a Corografia de Costa e as duas obras do padre Luís Cardoso, pelos motivos apontados, ficamos com contagens parcelares para $1709-12,1721.1758$ e 1763 a Lista do Marquês de Abrantes publicada por Caetano de Lima e de datacão duvidosa e ainda o censo de 1798 (com algumas limitacões).

A alta correlacão estatística entre estas fontes sugere aue a um nível global, os valores são produzidos por uma lógica semelhante e. por isso comparáveis. Contudo. este tipo de validacão estatística asseơura-nos a validade das informações somente a nível global. Nestas contagens existem sempre variacões de tino aleatório: o pároco engana-se numa centena ao fazer os totais do rol de confessados dois dícitos são trocados numa cópia etc. Variacões ocasionais deste tipo tendem a anular-se entre si quando se agregam os valores. Contudo tornam-se relevantes auando a pesauisa se interessa nelas naróauias individualmente. Assim, depois de separar as fontes entre "seguras" e não-utilizáveis, examinámos comparativamente os dados das fontes "seguras». paróquia a paróquia, para filtrar os valores que parecessem inverosímeis, provavelmente devido a erros aleatórios. $\mathrm{O}$ principal critério utilizado baseou-se sobretudo no princípio do afastamento 
à média geral da paróquia, obtida a partir de todas as fontes "seguras»: quando possuíamos várias contagens para a mesma paróquia, e um dos valores destoava grandemente dos outros, esse valor era posto de lado. Um segundo critério foi utilizado no sentido de valorizar as informações mais detalhadas: se uma contagem apresentava, por exemplo, o número de fogos, as pessoas maiores e as menores (e sendo estes valores coerentes entre si), e outra contagem somente $o$ número de fogos, destoando o valor das duas, a primeira contagem era valorizada por ser considerado menos provável a existência de um erro aleatório que afectasse três contagens ao mesmo tempo. Esta comparação, paróquia a paróquia, eliminou relativamente poucas informações, mas teve como efeito importante detectar um número elevado de troca de fogos por almas, na nossa recolha inicial. Com efeito muitas fontes dão-nos a população em termos de «fregueses» ou "vizinhos", sendo difícil, na ausência de termos de comparação, saber se se trata de almas ou de fogos. O confronto com outras fontes esclarece muitas vezes essas indefinições $\left({ }^{52}\right)$.

(52) Exemplo: a freguesia do Espinhal. para a qual tínhamos os seguintes valores:

Registo de róis de 1709: 1055 maiores, 71 menores

Registo de róis de 1710: 972 maiores, 95 menores

Informações de 1721: 1104 almas

Caetano de Lima: 106 fogos, 509 almas

1758: 345 fogos, 1120 almas

1798: 422 fogos.

Era evidente que havia um erro em Caetano de Lima. Esse valor foi, primeiro confirmado e depois abandonado. Outro exemplo - Figueiró dos Vinhos:

Registo de róis de 1710: 1685 almas

Registo de róis de 1711: 1781 almas

Registo de róis de 1712: 1752 almas

Informações de 1721: 177 fogos e 1656 almas

Caetano de Lima: 535 fogos e 1487 almas

1798: 547 fogos.

Neste caso a contagem de fogos de 1721 foi abandonada mas mantivemos a contagem de 1656 almas. Este processo de limpeza adicional tornou os cálculos menos sujeitos a flutuações aleatórias. Teríamos querido tornar este processo de verificação de valores a nível paroquial quase "automático», para ser passível de ser reproduzido noutros contextos geográficos (eventualmente por outros investigadores). Contudo, as decisões tomadas, não sendo arbitrárias, envolviam critérios por vezes difíceis de quantificar. Não entramos só em linha de conta com os valores em si, mas também com aspectos ligados ao grau de detalhe de cada informação e ainda a outros factores que intuitivamente não podemos deixar de considerar, como, por exemplo, o facto de que uma obra impressa ter sempre mais probabilidades de ter um erro aleatório num número concreto do que a informação original do punho do pároco, simplesmente por os valo- 
Uma dificuldade adicional no tratamento da informação recolhida reside na conversão de fogos em habitantes, ou melhor, em "almas» $\left({ }^{53}\right)$. Essa conversão é necessária porque algumas das fontes nos fornecem contagens de fogos e outras contagens de almas. Algumas delas, como o registo de róis e as informações de 1721 e 1758, fornecem, em paróquias diferentes, totais em unidades diferentes. A Lista de Caetano de Lima fornece, salvo raras excepções, fogos e almas. As informações de 1763 dão sempre fogos, assim como o censo de $1798\left({ }^{54}\right)$. E assim frequente que, para uma mesma paróquia, tenhamos contagens em unidades diferentes: por exemplo, o número de fogos em 1709, o de almas em 1721. novamente fogos em 1763. Era, portanto, necessário converter todas as contagens a uma unidade comum, que permitisse comparar. dentro de uma paróquia, contagens de fogos de determinados anos, com contagens de almas de outros.

Para evitar a utilização de um coeficiente global (que poderia esconder significativas variações regionais da proporção almas/fogos), procurou-se calcular o coeficiente próprio

res terem passado por várias cópias e pela composição tipográfica. Um dos problemas que procurámos evitar foi o de, por este processo, anular variações reais, de grande amplitude, que tivessem ocorrido de facto. É possível, contudo, que ocasionalmente casos desses tenham ocorrido.

(53) As fontes que utilizámos baseiam-se em respostas de párocos cujo conhecimento quantitativo da população paroquial se funda na compilação anual do rol de confessados. No rol de confessados não são inscritos todos os habitantes, mas somente os maiores de 7 anos, em idade de confessar. As constituições do bispado determinam a elaboração dos róis nos seguintes termos: "Ordenamos e mandamos, que todos os Priores, Reytores e Curas, de nosso Bispado, em cada hu anno, tanto que vier a Septuagesima, fação rol por si, e não por outrem; o qual acabarão até a Quinquagesima. em que ponhão todos seus freguezes por seus nomes, e sobrenomes, e a rua e lugar, onde viverem; e porão os de quatorze annos para sima em huma parte; e os moços de sete até quatorze em outra» (Tit. IV, Constituição, I, p. 14). Estes eram as «almas». Os habitantes efectivos da paróquia são sempre mais do que os inscritos no rol (não entrando aqui no problema dos «ausentes») sobretudo por essa não contagem dos menores de 7 anos. Não é possível, à escala a que estamos a trabalhar, "recuperar» essas crianças perdidas. O mais que se pode fazer é estimar, com base numa distribuição por idades tipo, qual a relação das almas para os habitantes, como faremos mais adiante. Para evitar confusões terminológicas utilizamos o termo "almas» para os maiores de 7 anos e em geral, trabalharemos a esse nível nas nossas contas de população. A expressão "habitantes» reservamo-la para todos os membros da paróquia.

(54) As outras corografias, abandonadas para o cômputo final, fornecem também sempre fogos. 
a cada paróquia a partir das fontes que forneciam, para o mesmo ano, contagens simultâneas de fogos e almas. Quando, numa mesma paróquia, existiam várias dessas contagens simultâneas, calculou-se a média dos vários coeficientes. Com base nessa média converteram-se as contagens isoladas de fogos ou almas nas restantes fontes. Quando não se possuía nenhuma contagem simultânea, não se fez conversão alguma $\left({ }^{55}\right)$.

Relembre-se o nosso objectivo: pretendemos um valor representativo da população de cada paróquia num determinado período do século XVIII. Como para obter esse primeiro valor, iremos necessariamente combinar valores de anos diferentes, temos que saber até que ponto existe crescimento populacional diferenciado geograficamente. Em qualquer dos casos os valores obtidos serão aproximados e bastante sujeitos a erros de pormenor, só sendo utilizáveis para interpretações baseadas em grandes classes de valores.

Existem várias maneiras de chegar a um valor que represente a população das nossas paróquias, partindo da informação que dispomos. Uma delas seria calcular a tendência de evolução da população, paróquia a paróquia, por regressão linear, e projectar o quantitativo para um mesmo ano em todas elas. De modo semelhante poder-se-iam utilizar as taxas de crescimento calculadas localmente. Contudo, estes processos são sensíveis a variações ou erros nos valores extremos das mini-séries paroquiais e, de certo modo são excessivos perante o grau de fiabilidade que reconhecemos às contagens tomadas individualmente. Utilizámos em vez disso um processo que consistiu, simplesmente, em fazer a média das várias contagens disponíveis (exceptuando 1798, para restringir o âmbito cronológico dos dados utilizados). Para efeitos de controle dos resultados obtidos, calculou-se ainda a média do valor dos anos utilizados para ter um índice do momento cronológico a que corresponde a média da população obtida.

${ }^{(55)} \mathrm{Na}$ prática, este método teve como consequência que a Lista de Caetano de Lima tenha tido um papel importante na determinação dos coeficientes paroquiais, ao contribuir com 305 leituras simultâneas. O registo de róis e as informações de 1721 foram as outras fontes importantes sobre este aspecto. Este tipo de cálculo é permeável a variações dos coeficientes ao longo do tempo, uma vez que iremos multiplicar fogos de 1763 por um multiplicador calculado a partir de fontes de 1709, 1721 ou talvez 1732. Como veremos mais adiante, existem realmente variações do número médio de almas por fogo ao longo do tempo e tivemos que controlar o efeito que essas alterações poderiam ter nos nossos resultados. 
Esse índice permite ter uma ideia das variações que houve na combinação de fontes utilizadas, possibilitando distinguir aquelas paróquias cujo valor representativo foi conseguido com fontes mais antigas daquelas em que se usaram fontes mais recentes $\left({ }^{56}\right)$.

Por este processo ficámos com um valor representativo da população de cada paróquia e foi a série desses valores que utilizámos como base dos vários cartogramas que fornecem o número de habitantes por paróquia e a densidade populacional. É, em certa medida, um resultado pobre de precisão: os valores obtidos representam aproximações extraídas de fontes diversas, que, por isso, introduzem flutuações cronológicas. Não é. não o esqueçamos, completamente sincrónica a imagem obtida.

\subsection{População, densidade, crescimento e fogos}

Com base nos procedimentos que se acabam de descrever obtiveram-se os seguintes resultados. Das 369 paróquias da diocese, temos valores para 360 que somam cerca de 264000 almas (arredondando ao milhar). As paróquias menos popu-

(56) Eis um exemplo do cálculo, para a paróquia de Alrote. Possuíamos as seguintes contagens:

$\begin{array}{lrc}\text { ano } & \text { fogos } & \text { almas } \\ 1709 & 106 & 341 \\ 1710 & 106 & 343 \\ 1711 & 109 & 361 \\ 1721 & 110 & - \\ \text { Lima } & 115 & 385 \\ 1763 & 108 & -\end{array}$

Em primeiro lugar calculámos o coeficiente global almas/fogos, para estimar um valor plausível do total de almas em 1721 e 1763. Esse coeficiente é obtido a partir da média dos vários coeficientes anuais que é possível calcular. O resultado é 3,28 , que multiplicado pelos fogos dá 361 e 354 almas, em 1721 e 1763 , respectivamente. A média global de almas calculada seria de 357,5. que utilizaríamos como valor representativo desta paróquia. $\mathrm{O}$ processo que produziu os dados finais utilizados neste artigo introduziu uma pequena variante. Calcularam-se primeiro os valores médios das várias entradas do registo de róis (neste exemplo 1709, 1710 e 1711), que assim passou a ter um valor único, para impedir que uma eventual particularidade do registo de róis pesasse demais. Em vez de 358 almas passaríamos a ter 363 para um ano médio que se situaria em 1731,5 (assumindo que Lima é de 1732). Note-se que calcular a média dos anos ou projectar o valor médio da população no tempo a partir de uma regressão linear é exactamente a mesma coisa (a recta de regressão passa sempre pelo ponto definido pela média das duas variáveis). 
losas andam à volta de 100 almas, as maiores acima de 3000 (Soure, Pombal, Ilhavo) ${ }^{57}$ ). A média global é de 732 almas por paróquia.

O ano médio desta contagem é cerca de 1730 , com $90 \%$ dos valores entre 1720 e 1740, aceitando a Lista de Lima como sendo de 1732 . Para as nove paróquias que nos faltam, podemos basear-nos nos valores do censo de 1798 para estimar que mal somariam 1000 fogos, nesta altura, o que equivaleria a 3300 almas no máximo (usando o coeficiente de 3,3 almas por fogo, que é a que se obtém na média geral, como veremos mais adiante). Somando estas às 264000 anteriores, obtemos um número próximo de 270000 almas que é a nossa estimativa para os anos 30 do século XVIII. Se se demonstrar que os valores de Caetano de Lima estão mal datados e que são anteriores cerca de 10 anos, então as nossas 270000 almas seriam um pouco mais recuados no tempo.

O cartograma número 1 mostra a distribuição da população em valores absolutos. Vejamos, em primeiro lugar as zonas de menor população: todo o arcediagado de Seia, a parte leste do arcediagado de Vouga, e a ponta Sul do arcediagado de Penela. $\mathrm{O}$ grosso da população concentra-se no litoral (Quiaios está muito próximo das mil almas, e junto com a Tocha, para a qual não temos informação, cria uma ideia de discontinuidade mais aparente que real). No interior existem igualmente fortes concentrações humanas no vale do Vouga e alguns núcleos fortes no arcediagado de Penela (Soure, Pombal, Redinha, Santiago da Guarda, por um lado, e a linha Góis, Lousã, Miranda do Corvo e Penela por outro). Coimbra, como é evidente, e o Baixo Mondego, que aqui não sobressai mais claramente devido à exiguidade das áreas paroquiais que não permite maiores aglomerados, são também regiões populosas.

Muito mais interessante que os valores globais são as densidades populacionais $\left({ }^{58}\right)$. A área global da diocese é de cerca de $7500 \mathrm{~km} 2$, o que nos dá, para uma população de cerca de 270000 almas uma densidade global de 35,7 (ou aproximadamente 11 fogos por $\mathrm{km} 2$ ) ${ }^{(59)}$.

(57) Coimbra e Aveiro, somando as várias paróquias, têm, evidentemente, valores superiores: à volta de 10000 almas e 4500 respectivamente.

(58) As áreas que utilizamos no cálculo da densidade são obtidas a partir dos limites paroquiais reconstituídos do modo descrito no início deste artigo. Sobrestimam, talvez, ligeiramente, a extensão das areias litorais.

(59) Confronte-se com os resultados obtidos por A. Hespanha com base na Corografia de Costa, ob. cit., vol. I, pp, 96-112. Os valores 
O cartograma 2 é certamente um dos mais interessantes e significativos de entre os que aqui apresentamos. A imagem que obtemos é espantosamente coerente. Sobressai agora uma população instalada entre as areias do litoral e as asperezas das serras. Vêem-se claramente os valores do Vouga e o Baixo Mondego, zonas de grande densidade, a que se junta uma fiada de paróquias em Seia, entre a serra e o Mondego, tudo com densidades superiores a 60 almas por $\mathrm{km} 2$. E vê-se sobretudo, como notou Amorim Girão para a época contemporânea, a fertilidade dos solos: a areia e o xisto dificultam a fixação e é nos terrenos férteis entre o mar e a serra que a população se concentra $\left({ }^{60}\right)$. As zonas de menor densidade (abaixo das 20 almas por $\mathrm{km} 2$ ), situam-se nas serras e no litoral. Vemos a serra da Estrela e os seus prolongamentos, e, a Norte do Mondego, o Caramulo e Bussaco (mas já não aquelas paróquias debruçadas sobre o Dão - Santa Comba Dão, Vimieiro, S. Joaninho, Couto do Mosteiro - contraste que a carta de 1940 assinala igualmente com toda a clareza). Ressaltam também claros os areais do litoral que aqui nos aparecem ainda quase desertos, cortados pela alta densidade da foz do Vouga e da do Mondego. Por fim repare-se a alta densidade da ponta Norte da diocese, as terras férteis do termo da Feira.

Mesmo não tendo valores sistemáticos para todos os anos, podem-se constituir grupos de paróquias mais ou menos numerosos para testar o crescimento a que se assiste de fonte para fonte. Assim em 130 paróquias em que temos contagens de almas no livro de registo de róis de confessados (1709-12) e nas informações de 1721 , o total passa de 88608 para 95393 , um aumento de $7,66 \%$, correspondendo a uma taxa de crescimento médio anual de $0,71 \%\left({ }^{61}\right)$. Uma população que cresce a este ritmo demora cerca de 130 anos a duplicar de tamanho.

aí dados, por serem agregados por comarcas. não são directamente comparáveis. Contudo notamos a comarca de Coimbra com 25,01 hab./km2 e a de Esgueira com 38,19, valores talvez baixos em comparação com os nossos para almas por $\mathrm{km} 2$. Compare-se também o Mapa IV da referida obra com o nosso mapa 2.

(60) Ver Amorim Girão, «Densidade da população por freguesias», Biblos, XXV, 1949, pp. 345-387 (comentário à carta Densidade da população por Freguesias, escala 1/500.000, Coimbra, Centro de Estudos Geográficos da Faculdade de Letras de Coimbra, 1948). Compare-se aquela carta a esta que aqui comentamos. A permanência das distribuições é extraordinária, e manifesta-se em pormenores inesperados. 3 anos.

(ө1) Os valores do registo de róis correspondem à média dos 
Ignorando a Lista de Lima, que obviamente não pode ser usada para o cálculo do crescimento, podemos relacionar as informações de $1721 \mathrm{com}$ as de 1758 e de 1763 . Para as 54 paróquias em que temos ambos os valores o número de fogos cresce entre 1721 e 1758 cerca de $12,22 \%$, com uma média anual de $0,31 \%$. A mesma desaceleração constata-se se utilizarmos os valores de 1721 e 1763: 53 paróquias, variação global de $10,9 \%$, taxa média de crescimento anual de $0,25 \%$. Finalmente, o valor provavelmente mais seguro, pela quantidade de paróquias e a diferença cronológica é calculado a partir de 295 paróquias entre 1721 e 1798 que cresceram em média $0,22 \%$ ao ano, o que equivale a um período de duplicação de 317 anos. Obviamente que estes coeficientes. ao serem calculados a partir de momentos afastados no tempo, escondem eventuais alterações entre os dois pontos utilizados. Assim não pretendemos concluir que a população cresceu gradualmente $0,22 \%$ ao ano entre 1721 e 1798, mas apenas que esse é o crescimento médio resultante de uma progressão que decerto foi acidentada.

Daqui extraímos uma primeira constatação - a existência de dois tempos: um crescimento mais rápido é detectável entre 1710 e 1720 , e um crescimento mais lento, a menos de metade do ritmo, daí em diante. Não podemos saber o momento exacto em que cada fase começa e acaba.

É possível que o crescimento que detectamos na segunda década do século XVIII corresponda a um movimento de recuperação da crise de 1707-1711, devida a uma série de maus anos agrícolas que tiveram consequências graves na produção de cereais, agravadas pelas dificuldades internas e externas provocadas pela guerra da Sucessão. Os preços dos cereais subiram em flecha em numerosos mercados do país, e a degradação das condições de subsistência ficou registada por testemunhos contemporâneos, e por motins populares $\left({ }^{62}\right)$. Seriam assim de plena crise os dados que nos fornecem os registos de róis dos anos 1709-1712, sugerindo que a diferença encontrada em 1721 se deve a uma recuperação, mais do que um crescimento de base $\left({ }^{63}\right)$.

(62) Baseamo-nos aqui em Luís Ferrand de Almeida, «Motins populares no tempo de D. João V. Breves notas e alguns documentos", Revista de História das Ideias, pp. 321-343, com preciosas referências bibliográficas. Completar com do mesmo avtor, "Os motins de Abrantes e Viseu (1708 e 1710)», Revista Portuguesa de História, XXII, 1985, pp. 137-148.

(83) Note-se que 1721 é contudo um pouco cedo para se manifestar uma recuperação. Se a crise do início do século dura até 1712, 
Com base nestas taxas de crescimento e num valor global de 270000 almas, grosso modo à volta de 1730 , podemos projectar para os finais do século cerca de 320000 almas. Projeç̧ão muito aproximativa, para ser confirmada futuramente $\left(^{64}\right)$. $O$ peso no total do país destes números, aceitando como verosímil uma população de 2,5 milhões à volta de 1730 indicam que a diocese de Coimbra constituiria pouco mais de $10 \%$ da população nacional $\left({ }^{65}\right)$.

Ensaiemos agora uma visão regional do crescimento populacional. O cálculo de taxas de crescimento, paróquia a paróquia é bastante difícil com as fontes disponíveis. Se, com efeito, a agregação de valores tende a diminuir as variações aleatórias ocasionais, ao medirmos o crescimento a nível paroquial, corremos os riscos inerentes aos pequenos números. Interessa por isso escolher momentos consideravelmente afastados no tempo, procurando suprir com a distância cronológica as distorções inevitáveis. Cartografámos assim as taxas de crescimento entre 1721 e o censo de Pina Manique de 1798 (aliás é a única utilização que fazemos do censo). Os valores são inseguros (o próprio censo o é, em determinadas regiões como a comarca de Aveiro e de Montemor-o-Velho) e devem ser recebidos com reserva.

Uma característica parece-nos contudo sobressair e ser de pacífica aceitação: a de haver, em termos gerais, uma relação inversa entre a densidade populacional e o crescimento. Isso é claro no litoral, onde se cresce, em alguns locais, três vezes acima da média geral. como se mostra no cartograma 3. São excepção Aveiro e, mais ao Sul, aparente-

e a recuperação começa a partir daí, os novos efectivos demográficos demorarão cerca de 7 anos para virem a ser registados em contagens feitas, com base nos róis de confessados. Os valores da diocese de Coimbra são baixos se comparados, por exemplo, ao Algarve, onde podemos ver um crescimento de $1,18 \%$ ao ano entre 1717 e 1722 , e de $0,53 \%$ entre 1722 e 1743 . notando-se igualmente uma travagem no crescimento que Romero Magalhães situa a partir de 1731 (ob. cit. 1,16 e 2,1077). O concelho de Castelo Branco, segundo um estudo recente, teria crescido $0,55 \%$ ao ano entre 1758 e 1801 (ver Maria Luís Rocha Pinto, «Para uma crítica das fontes: a população do concelho de Castelo Branco em meados do século XVIII", in Estudos e ensaios em homenagem a Vitorino Magalhães Godinho, Lisboa, Sá da Costa, 1988, pp. 303-311).

(64) A projecção bate certo com os 90000 fogos que somam 330 paróquias da diocese no censo de Pina Manique (falta-nos dados para 39 paróquias). Multiplicando por 3,3 obtemos 297000 almas, que, somados às paróquias em falta, não ficaria muito longe dos 320000 projectados.

(85) Ver Romero Magalhães, ob. cit., vol. 2, pp. 1081 a 1084. 
mente Vagos (embora sejam de pouca confiança os valores de 1798 para esta paróquia). Os vales do Vouga e o Baixo Mondego dão a imagem de regiões saturadas que crescem devagar. De modo semelhante ao litoral temos as regiões de Seia, em geral a crescerem acima da média, especialmente a serra pouco povoada. Note-se, porém, que o crescimento real, em termos absolutos vem do litoral. A serra cresce, sobretudo no arcediagado de Seia, mas os valores brutos são muito baixos. É relacionando este mapa com o dos valores absolutos de população (cartograma 1) que se obtém uma ideia do peso de cada região no crescimento global da população diocesana.

Que as áreas baixamente povoadas cresçam mais depressa que as menos povoadas, não é mais do que lógico. Concretamente no litoral, a menor pressão demográfica constitui-se como aliciante à colonização. Menos esperado seria o crescimento das serras do arcediagado de Seia. Embora em pequenos números, as populações do Alto Mondego sobrepovoado parecem subir cada vez mais alto os vales das ribeiras que correm para os afluentes da margem esquerda do Mondego.

Note-se ainda que o crescimento a que assistimos está longe de ser em moldes que provoquem uma subversão da distribuição da densidade populacional a médio ou mesmo a longo prazo. Um mapa da densidade feito a partir do censo de 1798 dá basicamente a mesma imagem que o nosso cartograma 2. E se olharmos com atenção para a carta de Amorim Girão, com dados de 1940, vemos mais permanências que diferenças. A relação da população com o território surge-nos como estrutura de longa duração que determina um fluxo plurissecular de pessoas ${ }^{\left({ }^{86}\right)}$.

Não deixa de ser interessante estudar mais de perto os processos concretos a operar neste crescimento diferenciado. Faria sentido, com base na visão geral aqui apresentada, estudar em detalhe, ao nível de reconstituição demográfica de comunidades, paróquias das diferentes áreas que aqui se delineam, sobretudo para deslindar o papel relativo da imigração e da nupcialidade no crescimento do litoral e das serras.

O facto de grande parte das contagens da população, anteriores à época dos censos "científicos". fornecerem contagens de fogos e não de indivíduos, pôs desde há muito no

(68) Ver elementos adicionais para esta ideia, a nível de todo o país, em A. Hespanha, no local citado na nota 32 , em especial pp. 103-105, e mapa II. 
centro das atenções dos historiadores da população a questão da conversão de fogos em habitantes $\left({ }^{67}\right)$.

Referimos acima que, quando necessitámos de fazer tal conversão, optámos por utilizar somente coeficientes que pudessem ser calculados a partir de informações simultâneas de fogos e almas. Assim calculámos coeficientes de almas por fogos para 336 paróquias, baseados nos valores médios obtidos no registo de róis de confessados nas informações paroquiais de 1758 e de 1721 e na Geografia Histórica de Caetano de Lima. O valor médio (média dos coeficientes) para essas 336 paróquias é de 3,27 almas por fogo. Analisando a distribuição de valores à volta da média vê-se que $78 \%$ dos casos estão contidos entre os valores 3 e 4 (ver gráfico 5).

\section{Gráfico 5: distribuição das paróquias por número de almas por fogo}

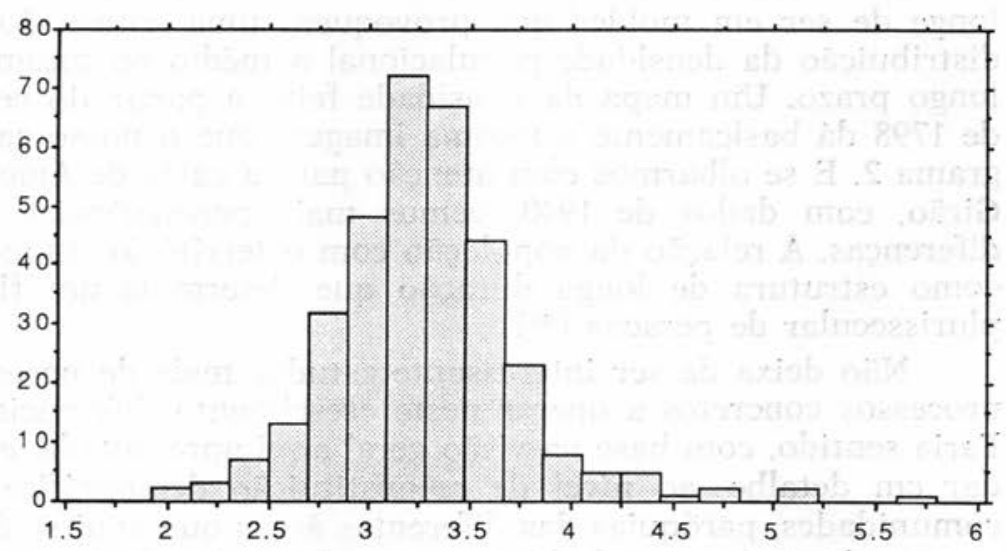

Haverá uma variação cronológica por detrás destes valores globais? Vejamos os valores fonte a fonte. Registo de róis (1709-1712): 141 leituras simultâneas de almas e fogos, coeficiente 2,94; informações de 1721: 124 paróquias 3.37; Caetano de Lima: 295 coeficiente 3,32, informações de 1758, 95 paróquias 3,34 .

(67) Para um apanhado geral da literatura sobre o assunto é pertinente ver A. Hespanha, ob. cit., pp. 95-96. 
Assim, à excepção dos valores do registo de róis, os coeficientes obtidos situam-se à volta de 3,3 almas por fogo $\left.{ }^{68}\right)$. A baixa do coeficiente nos anos 1709-1712, liga-se certamente com a crise agrícola dos anos 1707-1711. Sendo assim, um dos efeitos da crise seria a baixa do número de almas por fogo. Isto tem consequências importantes para a análise de dados demográficos, uma vez que sugere que o coeficiente almas/fogos pode sofrer variações conjunturais significativas (para além de uma eventual tendência a longo prazo), tendo como corolário que a interpretação de séries de fogos pode esconder variações importantes na população $\left({ }^{69}\right)$.

Qual o peso dos menores de 7 anos? Necessitaríamos de aproximações à estrutura de idades das populações de Antigo Regime, para poder calcular esse valor. Outros estudos apresentam valores entre 14 e $17 \%$ da população total $\left({ }^{70}\right)$. Os dados de um censo eclesiástico de 1798, apresentados por Carneiro da Silva, distinguem os menores de 7 anos, e têm a vantagem de corresponder ao bispado de Coimbra $\left({ }^{71}\right)$. Num total de 278 paróquias $\left({ }^{72}\right)$ temos 285033 habitantes para 72444 fogos, ou seja um coeficiente muito próximo de 4 (3.93). Mas se retirarmos os menores de 7 anos, ficamos com 232194 almas - o coeficiente passa a 3,178. Apesar destes números merecerem todo o cuidado, cremos aue a ideia geral é esta: à volta de 3,3 maiores de 7 anos por fogo (almas), mas 4 ou mais habitantes, entrando em linha de conta com os menores.

(68) Confirmando, de modo que cremos significativo do ponto de vista estatístico, a escolha de A. Hespanha, com as ressalvas interpretativas assinaladas a seguir no texto.

(69) Podemos dar um exemplo. Como ficou dito acima o número de almas cresce $7,66 \%$ entre $1709-12$ e 1721 . Contudo, se o coeficiente almas fogos no primeiro momento é mais baixo que no segundo, é natural que a evolução medida em fogos dê uma imagem diferente. Para o detectar isolámos um grupo de paróquias para as quais tínhamos contagens simultâneas de fogos em 1709 e 1721. Neste grupo o número de almas passou de 19580 para 21619 (mais 10\%) enquanto que o número de fogos passou de 6480 para 6252 (mais 0,69\%). O coeficiente que era de 3,0 almas por fogos em 1709 subiu a 3,3 em 1721 . Em conclusão a população cresceu, mantendo-se o número de fogos quase imutável. Eis algo que seria de confirmar para outros casos e explicar por um modelo adequado.

(70) Maria Luis Rocha Pinto, ob. cit., baseando-se em J. Nazareth e F. Sousa, "Aspectos sociodemográficos de Salvaterra de Magos nos finais do século XVIII». Análise Social (66), 1981-2. ${ }^{\circ}$ pp. 315-373.

(71) Ver A. Carneiro da Silva, "A evolução da população Coimbrã....», pp. 248-249. Os dados foram recolhidos no Investigador Português em Inglaterra.

(72) O bispado de Coimbra tinha entretanto perdido a comarca da Esgueira para o novo bispado de Aveiro e algumas paróquias para o bispado da Guarda. 
Acrescentemos dois factos adicionais. O padre Luís Cardoso, que manuseou não poucos dados populacionais durante a sua vida, usava um coeficiente de 5,5 habitantes por fogo para converter informações fornecidas pelos párocos. Sabêmo-lo através da comparação feita entre as informações de 1758 e o Portugal Sacro-Profano. Na obra impressa aparecem sempre contagens de fogos mas em dois casos que detectámos, os párocos forneceram apenas contagens de almas. Cadima (2400 almas) e Cioga do Campo (518) - O Portugal Sacro-Profano dá, respectivamente, os valores de 434 e 94 vizinhos (divisão por 5,5 tolerando o arredondamento).

Coloquemos, finalmente uma última questão. Variará o coeficiente no espaço de uma maneira não aleatória? E, sobretudo, variará de algum modo relacionável com os claros padrões regionais que vimos nas cartas de densidade e, em menor grau, de crescimento? $\left.{ }^{73}\right)$. A resposta está longe de ser clara. Cartografámos a média de almas por fogo em cada paróquia a partir das fontes disponíveis e obtivemos o mapa 4, que está distante de ser claro. Sobressai uma mancha escura que parte da foz do Mondego e escorre até Montemor-o-Velho. Mais a Sul no limite da diocese em Penela, outra mancha parece configurar-se (Louriçal, Mata Mourisca, Pombal, Santiago de Litém, Redinha, Santiago da Guarda - mas já não Soure). $\mathrm{O}$ resto é um mosaico salpicado com alguns grupos de paróquias contíguas associadas no mesmo escalão de valores, não chegando a formar zonas claras.

Esta imagem indefinida é confirmada pelos baixos coeficientes de correlação que têm os coeficientes almas/fogos fornecidos pelas várias fontes. Apesar dos quantitativos da população terem correlações elevadas (acima de $0,9 \%$ na maior parte dos casos), os coeficientes almas/fogos apresentam uma relação muito mais fraca, embora existente $\left({ }^{74}\right)$.

(73) Variacões regionais no número de almas por fogos seriam a consequência lógica de diferentes sistemas familiares e de diferentes formas preponderantes de agregados, mediatizada pelos critérios utilizados pelos párocos na elaboração dos róis. Para o enquadramento do estudo das variações regionais da estrutura dos agregados domésticos e das variáveis demográficas associadas ver Robert Rowland, «Sistemas familiares e padrões demográficos em Portugal», Ler História, n. 3,1984 , pp. 13-32.

(74) Eis os coeficientes de correlação entre os coeficientes almas /fogos das várias fontes (entre parêntesis o número de paróquias utilizado no cálculo)

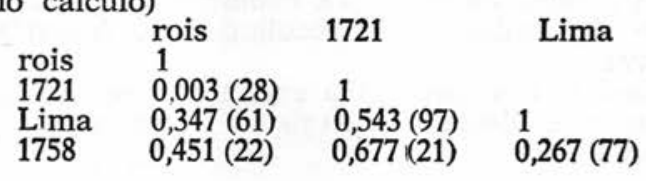




\section{Oragos de invocação das freguesias}

\subsection{Estabelecimento do mapa de oragos}

Os mapas dos oragos das freguesias foram produzidos com base em informaçōes constantes em várias corografias e dicionários geográficos compilados no século XVIII. Usaram-se concretamente o Portugal Sacro-Profano de Paulo Dias de Niza, o Dicionário Geográfico de Luís Cardoso e a Geografia Histórica de Luis Caetano de Lima. A partir das indicações aí colhidas, constitui-se uma base de dados que permitiu a ordenação, análise e comparação das diversas informações fornecidas.

Uma vez que as informações constantes nestas obras eram provenientes de inquéritos, que tinham a sua origem nos párocos locais das freguesias, é de crer que os seus dados sejam de confiança, a este nível. O facto de aproximadamente em $95 \%$ dos casos as três fontes usadas serem concordantes entre si é também uma prova da sua fidelidade. Nalguns casos, contudo, existem discrepâncias que foram resolvidas através do recurso aos "livros de devassa" das visitas pastorais da diocese de Coimbra $\left({ }^{75}\right)$. Nestes livros, antes do início do registo dos depoimentos das várias testemunhas, o secretário da visita escrevia um "termo de abertura" onde, de forma regular e estereotipada, anotava, entre outras informações, o nome da freguesia e respectivo orago. Este processo serviu também para os casos em que as obras referidas eram omissas em relação a certas freguesias $\left({ }^{76}\right)$.

Avelino Jesus da Costa mostrou. para o caso da diocese de Braga, que o quadro dos oragos das freguesias está praticamente estabilizado no século XVI $\left({ }^{77}\right)$. E pois de crer que

(75) . Demonstrou-se que essas discrepâncias correspondiam a erros e não à mudança de oragos ao longo do tempo. Apresenta-se aqui a lista das freguesias onde havia discrepâncias entre as fontes: Avelãs de Cima, S. João de Loure, Cioga do Camno, Bolho, Serpins, Ventosa do Bairro, Lagos da Beira, Sabugueiro, Coimbra Almedina e Cerdeira.

(76) Situação verificada apenas em Carragosela, Doninhas, Fermentelos, Lamarosa, Ois do Bairro e Ourentã.

(77) Avelino Jesus da Costa refere que. segundo o Direito Canónico contemporâneo. os titulares das igrejas não podem ser mudados uma vez feita a dedicação destas. Tal proibição parece ter ficado estabelecida definitivamente no século XVI. Por outro lado. ao comparar os vários censuais medievais de Braga e os oragos da actualidade, verificou que das 702 freguesias referidas apenas em 53 se registaram alterações nos oragos, o que corresponde a uma percentagem de 7,5\%. Cf. Avelino Jesus da Costa, ob. cit., pp. 345-348 e p. 354 Levantamentos sistemáticos das visitas pastorais de algumas fregue- 
os dados agora apresentados colhidos em documentação do século XVIII, sejam válidas para períodos anteriores ainda que possivelmente com pequenas alterações de pormenor $\left({ }^{78}\right)$.

\subsection{Os cultos predominantes}

A leitura do quadro n. ${ }^{\circ} 2$ permite conhecer quais os oragos de invocação mais frequentes nas 369 paróquias da diocese de Coimbra. O leque de figuras que foram escolhidas nas freguesias diocesanas era bastante alargado correspondendo a um total de 52 invocações diferentes.

Como facilmente se constata a mãe de Cristo foi a escolha preferida. Das 369 paróquias, $106(28,5 \%)$ tinham como orago principal a Virgem Maria, através da invocação dos seus vários mistérios e privilégios $\left({ }^{79}\right)$. Seguem-se os apóstolos Pedro e Tiago com, respectivamente, $28(7,5 \%)$ e $22(5,9 \%)$ freguesias de invocação. S. Miguel surge em quarto lugar ao constituir-se como orago de 21 freguesias (5,6\%). Ainda com um número significativo de invocações aparecem S. Martinho $\left({ }^{80}\right)$ e S. João Baptista com $16(4,31 \%)$, S. Sebastião com

sias da diocese de Coimbra, para o período de 1650-1780 (sensivelmente), feitos por alunos nossos integrados num projecto global de levantamento das visitas pastorais, confirmam esta tendência, uma vez que em nenhuma das freguesias estudadas se encontraram mudanças de orago. As freguesias em causa são: Arganil, Avô, Granja do Ulmeiro. Oliveira do Bairro, Sazes de Lorvão, S. Martinho do Bispo e Seixo da Beira.

${ }^{(78)}$ Sobre a introdução de alguns cultos posteriores ao século XIII na região entre Minho e Mondego, com destaque para o papel dos santos das ordens mendicantes (nomeadamente S. Francisco de Assis, S. Domingos e Santa Clara) e dos cultos de S. Bento (ligado aos Beneditinos) e de Maria Madalena (difundido pela Ordem de Cluny), ver Pierre David, Etudes historiques sur la Galice et le Portugal du VI au XII siècle, Coimbra, 1947, pp. 238-240.

(79) As designações mais comuns que se encontram na diocese de Coimbra são as de Nossa Senhora da Assunção e da Conceição, com 23 freguesias cada $(21,7 \%)$ depois Nossa Senhora da Graça com $14(13,2 \%)$, Nossa Senhora da Expectação com 7 (6,6\%), Nossa Senhora das Neves e do Rosário com $6(5,6 \%)$ e depois uma série variada de outras invocações: Alegria 1, Anunciação 2, Apresentação 2, Consolação 1, Finisterra 1. Maria 3, Natividade 3, Nazaré 1, O 4 Pranto 3, Purificação 3, Socorro 1 e Virtudes 1 . Sobre as várias invocações das freguesias de Portugal dedicadas a Nossa Senhora, segundo o censo da população de 1890, ver Avelino Jesus da Costa, «A Virgem Maria padroeira de Portugal», Lusitania Sacra, vol. II, 1957, p. 47.

${ }^{(80)}$ Como Pierre David afirma, ob. cit., p. 233, o culto de S. Martinho de Tours foi bastante forte entre o Minho e o Mondego e podia-se mesmo comparar em representatividade ao culto de Nossa Senhora, 
$14(3,7 \%)$ e o Divino Salvador com $13(3,5 \%)\left({ }^{81}\right)$. Todos os outros tem uma representatividade relativamente baixa.

Saliente-se ainda que a maioria destes oragos tinham um culto bastante antigo no território português, que remonta a períodos anteriores à formação da nacionalidade. Nas freguesias da diocese de Braga encontram-se muitos dos oragos agora apresentados $\left(^{82}\right)$. 0 que acaba de se dizer não invalida que alguns dos oragos da diocese de Coimbra no século XVIII tivessem origens menos remotas, como são os casos de S. José, padroeiro da freguesia das Lavegadas no arcediagado de Seia, ou ainda de Maria Madalena que surge em 5

ofuscando deste modo as invocações em honra do seu homónimo de Dume. Por outro lado, parece constatar-se com frequência alguma confusão entre as referências a estes dois santos, que Avelino Jesus da Costa já destacou, cf. $O$ bispo D. Pedro...., pp. 332 e 333. Também na diocese de Coimbra parece existir alguma confusão que não permite afirmar com segurança a que S. Martinho estavam dedicadas as paróquias da diocese. Esta situação, tem a agravante de na maior parte dos casos em que as fontes utilizadas especificam qual o S. Martinho de que se trata, referirem S. Martinho Bispo (portanto de Dume), o que iria contra as constatações dos dois autores referidos, que apontavam como o culto mais frequente o de S. Martinho de Tours. Por este motivo optámos por colocar sob a mesma designação de S. Martinho, todas as referências a este orago.

(81) Sobre a origem destes cultos bem como o de todos os que o quadro n. 2 apresenta e datas das suas comemorações, ver: Avelino Jesus da Costa, $O$ bispo D. Pedro.... vol. I, pp. 311-345; Joseph Piel, "Nomes dos santos tradicionais hispânicos na toponímia peninsular", Biblos, 1950, vol. XXV, pp. 287-353 e XXVI, pp. 281-314; Georges Cardoso, Agiologico Lusitano dos sanctos e varoens illustres em virtude do reino de Portugal, e suas conquistas, Lisboa, Oficina Craesbeckiana, 1612-1666. E Pierre David, "Les saints patrons d'églises entre Minho et Mondego jusqu'à la fin du XI siècle», Revista Portuguesa de História, tomo II, 1943, pp. 229-243.

(82) Os oragos da diocese de Coimbra que não conhecem qualquer invocação, como oragos, em Braga são: S. Sebastião, Santa Marinha, Espírito Santo, Madalena, Santo António, S. Domingos, Santa Catarina, S. Facundo. Santa Justa, S. Paulo, S. Silvestre, Santo Varão, Santo Aleixo, S. Gabriel, Santa Isabel, S. Jerónimo, S. José, S. Justo, Santa Susana e S. Teotónio.

Os oragos comuns às duas dioceses são: Maria, S. Pedro, S. Tiago, S. Miguel, S. Martinho, S. João Baptista, Divino Salvador, Santo André, S. Mamede, S. Paio, S. Julião, S. Vicente, Vera Cruz, Santa Eulália, S. Bartolomeu, S. João Evangelista, S. Tomé, Santo Estevão, Santo Isidoro, S. Lourenço e S. Mateus, Santa Comba, S. Cosme, S. Cristóvão, Santa Eufémia. S. Gens, Santa Luzia, S. Simão, Santo Adrião, S. Bento, Santa Cecília, Santa Cristina e S. Romão. 
freguesias, a saber: Agadão, Alvaiázere, Outil, Rabaçal e numa das freguesias da vila de Montemor-o-Velho $\left({ }^{83}\right)$.

Quadro n²

\begin{tabular}{lrr|lrr}
\hline Orago & Total & Percent. & Orago & Total & Percent. \\
\hline Maria & 106 & $28,73 \%$ & Catarina & 2 & $0,54 \%$ \\
Pedro & 28 & $7,59 \%$ & Comba & 2 & $0,54 \%$ \\
Tiago & 22 & $5,96 \%$ & Cosme & 2 & $0,54 \%$ \\
Miguel & 21 & $5,69 \%$ & Cristovão & 2 & $0,54 \%$ \\
Martinho & 16 & $4,34 \%$ & Eufémia & 2 & $0,54 \%$ \\
João Baptista & 16 & $4,34 \%$ & Facundo & 2 & $0,54 \%$ \\
Sebastião & 14 & $3,79 \%$ & Gens & 2 & $0,54 \%$ \\
Salvador & 13 & $3,52 \%$ & Justa & 2 & $0,54 \%$ \\
André & 10 & $2,71 \%$ & Luzia & 2 & $0,54 \%$ \\
Mamede & 9 & $2,44 \%$ & Paulo & 2 & $0,54 \%$ \\
Paio & 7 & $1,90 \%$ & Silvestre & 2 & $0,54 \%$ \\
Julião & 6 & $1,63 \%$ & Simão & 2 & $0,54 \%$ \\
Vicente & 6 & $1,63 \%$ & Varão & 2 & $0,54 \%$ \\
Marinha & 5 & $1,36 \%$ & Adrião & 1 & $0,27 \%$ \\
Vera Cruz & 5 & $1,36 \%$ & Aleixo & 1 & $0,27 \%$ \\
Espírito Santo & 5 & $1,36 \%$ & Bento & 1 & $0,27 \%$ \\
Eulália & 5 & $1,36 \%$ & Cecília & 1 & $0,27 \%$ \\
Madalena & 5 & $1,36 \%$ & Cristina & 1 & $0,27 \%$ \\
António & 4 & $1,08 \%$ & Gabriel & 1 & $0,27 \%$ \\
Bartolomeu & 4 & $1,08 \%$ & Isabel & 1 & $0,27 \%$ \\
Domingos & 4 & $1,08 \%$ & Jerónimo & 1 & $0,27 \%$ \\
Tomé & 4 & $1,08 \%$ & José & 1 & $0,27 \%$ \\
João & 3 & $0,81 \%$ & Justo & 1 & $0,27 \%$ \\
Estevão & 3 & $0,81 \%$ & Romão & 1 & $0,27 \%$ \\
Isidoro & 3 & $0,81 \%$ & Susana & 1 & $0,27 \%$ \\
Lourenço & 3 & $0,81 \%$ & Teotónio & 1 & $0,27 \%$ \\
Mateus & 3 & $0,81 \%$ & & & \\
\hline & & & Total Geral & 369 & $100 \%$ \\
& & & & &
\end{tabular}

Estes valores vêm confirmar as constatações de Avelino Jesus da Costa e de Pierre David que resumiríamos do seguinte

(83) O culto de S. José, segundo Pierre David, difundiu-se apenas a partir do século XVI devido à difusão que lhe foi dada principalmente pela ordem dos Carmelitas e teve uma grande aceitação popular. O culto de Maria Madalena é também de difusão tardia e surge através de duas vias principais, que eram a Ordem de Cluny e as peregrinações para Santiago de Compostela que passavam por Vezelay. A este respeito ver Pierre David, Etudes historiques...., p. 239. 
modo: grande supremacia dos oragos dedicados a Maria; seguindo-se-lhe como oragos mais frequentes os de S. Pedro, S. Tiago, S. Martinho, S. Miguel, S. João Baptista e Divino. Salvador, com a particularidade de, em relação a este último, se assistir a um paulatino decréscimo a favor de outros cultos $\left({ }^{84}\right)$. Contudo, a diocese de Coimbra apresenta algumas especificidades que queremos salientar. A primeira diz respeito ao número significativo de paróquias da invocação de $\mathrm{S}$. Sebastião, santo protector da peste, que se implanta sobretudo a partir do século XIV. Pierre David não encontrou uma única igreja cujo titular fosse S. Sebastião, para períodos anteriores ao século XII. A segunda, tem a ver com os valores relativos ao culto do Divino Salvador. Pierre David havia já apresentado a ideia de que o seu culto estava a ser progressivamente substituído $\left({ }^{85}\right)$. Parece-nos, no entanto, que os valores agora encontrados para a diocese de Coimbra $(3,52 \%)$ são extremamente baixos, principalmente se comparados com os revelados para Braga e Guimarães, onde as freguesias desta invocação atingiam, em 1980, os $10 \%$ segundo Avelino Jesus da Costa ${ }^{(88)}$.

\subsection{Geografia dos Patronos}

Os cartogramas n.os 5 a 12 representam os oito oragos mais frequentes nas freguesias da diocese, conforme o que acima fica exposto.

A partir da leitura do cartograma $n .^{\circ} 5$ verifica-se que as freguesias de invocação de Nossa Senhora aumentam claramente de Norte para Sul, ficando a grande maioria a Sul do Mondego $\left({ }^{87}\right)$. Repare-se ainda na existência de algumas man-

(84) Ver Avelino Jesus da Costa, $O$ bispo D. Pedro...., vol. I, pp. 353-356 e Pierre David, Etudes historiques, pp. 226-230 e 241 .

(85) Exemplos da substituição do orago do Salvador por outros podem ocorrerem, por exemplo, na freguesia da Vacariça cujo orago inicialmente lhe estava dedicado mas que, provavelmente por via popular, passou a ser conhecido por S. Vicente que era um dos seus patronos secundários, isto segundo Pierre David, Etudes historiques...., p. 226. Idêntico caso, mas para uma freguesia da diocese de Braga, pode ver-se em Avelino Jesus da Costa, $O$ bispo D. Pedro...., vol. I, pp. 351 .

(86) Cf. Avelino Jesus da Costa, $O$ bispo D. Pedro, vol. I, pp. 354.

(87) Esta tendência toi já salientada por Avelino Jesus da Costa e estaria, segundo ele. ligada ao facto de as terras do Sul do país serem locais de povoamento mais recente, surgindo assim numa altura em que o culto de Maria se tinha intensificado Cf. Avelino Jesus da Costa, A virgem Maria...., pp. 12-13. 
chas de grande implantação desta invocação. Uma na zona da margem esquerda do Mondego, correspondente ao extremo noroeste do arcediagado de Penela num triângulo delimitado pelas freguesias de Almagreira a Norte, de Lavos a Oeste e da Ega a Este. E uma outra, numa linha que se estende ao longo do limite sul do arcediagado de Seia, desde a freguesia do Fajão até Loriga.

As freguesias de invocação de S. Miguel. como se pode observar no cartograma n. ${ }^{\circ}$, apesar de uma aparente dispersão, parece terem alguma incidência no arcediagado de Vouga. Na realidade 11 das 21 freguesias com este orago ficam neste arcediagado, criando mesmo um núcleo, ainda que não muito concentrado, na zona central do referido arcediagado composto pelas freguesias de Soza, Recardães, Oliveira do Bairro, Vilarinho do Bairro. Vila Nova de Monsarros, Marmeleira e Sobral.

$\mathrm{O}$ culto de S. Martinho (cartograma n. ${ }^{\circ} 7$ ) também está ligado ao arcediagado de Vouga, pois pelo menos 9 das 17 freguesias onde este santo foi eleito como orago são de lá, o que corresponde a mais de $50 \%$.

0 cartograma $n .^{\circ} 8$ representa as freguesias de invocação de S. Sebastião e é, à semelhança do que acontece com as freguesias de invocação de Nossa Senhora, bastante elucidativo. A distribuição espacial desta invocação é muito clara e situa-se toda a Sul da linha do Mondego, limitando-se por isso aos arcediagados de Penela e Seia, com a única excepção da freguesia das Meãs do Campo, que contudo confina a Sul com o referido rio. Nota-se ainda no arcediagado de Seia, um núcleo de freguesias com esta invocação, a saber: Colmeal, Cepos, Secarias e Meda dos Mouros. A introdução relativamente tardia deste culto, como já foi referido, poderá ser responsável por esta situação, se partirmos do princípio que o estabelecimento do quadro paroquial nacional, se consolida numa fase mais tardia a Sul do que a Norte do Mondego $\left({ }^{88}\right)$.

0 culto de S. Pedro, como o cartograma n. 9 nos mostra, obedece também a uma disposição muito própria, que parece corresponder ao inverso do que se passava com as freguesias de invocação de Maria. Se como vimos, o número de freguesias de invocação de Maria aumentava de Norte para Sul, as freguesias dedicadas a S. Pedro crescem, em

(88) Sobre o Mondego e a Cordilheira Central como fronteira durante a reconquista ver José Mattoso, Identificação cie um país. Ensaio sobre as origens de Portugal 1096-1325, Lisboa, Editorial Estampa, 1985, vol. I, pp. 100-101. 
número, de Sul para Norte. A grande maioria das freguesias de sua invocação ficam no arcediagado de Vouga que corresponde ao Norte da diocese, na parte Norte do arcediagado de Seia e as poucas do arcediagado e Penela estão no seu topo Norte (com excepção de Rego da Murta). A lógica desta distribuição poderá estar precisamente no mesmo factor que explicava a distribuição do culto de S. Sebastião, só que aqui funcionando inversamente, uma vez que a introdução do culto de S. Pedro é muito antiga.

O cartograma n. ${ }^{\circ} 10$ mostra as freguesias de invocação de S. Tiago e revela uma relativa acentuação deste culto no arcediagado de Penela.

Finalmente, os cartogramas $n$.s $^{\text {s }} 11$ e 12 , que representam respectivamente as freguesias de invocação de S. João Baptista e do Divino Salvador, mostram uma grande dispersão destes dois oragos por todo o território da diocese e o seu peso relativamente diminuto, sem que se constituam zonas de grande intensificação das suas invocações.

Uma visão de conjunto do panorama de distribuição dos oragos das freguesias mostra como os oragos de culto mais antigo tendem a aumentar no sentido Norte da diocese e a diminuir no sentido Sul, enquanto que os de difusão mais recente apresentam uma disposição inversa. 0 exemplo mais paradigmático do primeiro caso é o das paróquias de invocação de S. Pedro, culto antigo que se encontra sobretudo no Norte da diocese. Para o segundo. Nossa Senhora e especialmente S. Sebastião, este praticamente sem expressão a Norte do Mondego, representam a distribuição típica dos cultos mais recentes.

O que acaba de se dizer evidencia como cerca de 700 anos depois os efeitos da Reconquista ainda se podem perscrutar por trás do quadro dos oragos das paróquias diocesanas. Os territórios mais a Sul, que foram apropriados mais tardiamente que a Norte, deram origem a que ali a criação de novos povoados de colonização cristã fosse mais recente e, por isso, mais aberta à intromissão de cultos de difusão mais tardia.

Saliente-se finalmente, que pela simples análise dos oragos das freguesias não é possível determinar qual a geografia dos cultos da diocese no século XVIII, uma vez que, como vimos, o quadro dos oragos não se altera praticamente desde a data da fundação da paróquia (os únicos casos de mudança de alguma maneira mais insistentes referem-se às paróquias de invocação do Divino Salvador). Tal noção. pode-se contudo obter com base nas invocações das capelas ou altares, de criação obviamente posterior à igreja matriz paro- 
quial e que, pelas suas flutuações, nos permitem ter uma ideia da evolução e aceitação das diferentes figuras do panteão cristão ao longo do tempo $\left({ }^{89}\right)$.

\section{5. $O$ "direito de apresentação» na diocese de Coimbra}

\subsection{Estabelecimento do mapa dos direitos de apresentação}

Os cartogramas representativos dos direitos de apresentação das freguesias foram produzidos por um processo semelhante ao dos mapas dos oragos, isto é, com base em informações constantes em várias corografias e dicionários geográficos compilados no século XVIII e já acima mencionados. As únicas fontes que não foram usadas para o estabelecimento dos mapas de oragos mas que agora o serão, são a Corografia de A. Costa e as informações paroquiais de 1721 .

A justificação da plausibilidade e confiança das indicações fornecidas a este nível pelas fontes mencionadas radica, a nosso ver, no facto de serem informações facultadas pelos próprios párocos, que obviamente sabiam muito bem quem tinham sido as pessoas que os tinham nomeado para proverem os lugares que ocupavam.

Além do motivo apresentado, que nos parece sobejamente satisfatório, acrescente-se que à semelhança do que aconteceu com as notícias relativas aos oragos, também na grande maioria dos casos as fontes usadas são concordantes entre si no tocante aos direitos de apresentação. Contudo, ao contrário dos oragos, os direitos de apresentação mudaram com mais frequência no tempo o que nos obrigou a distinguir se as discordâncias entre as fontes se deviam a erros ou a efectivas alterações. Foi possível, em alguns casos, esclarecer dúvidas a partir dos processos de colação dos párocos nas freguesias, existentes no Arquivo da Universidade de Coimbra $\left({ }^{80}\right)$.

(89) Num futuro próximo estaremos em condições de fornecer este quadro. Sobre a inventariação do fundo de capelas existentes no AUC veja-se Alice Correia Godinho Rodrigues e Filomena Maria Matos Ala Rodrigues, Institutições Pias (sécs. XVI-XX) em Documentação do cabido e mitra da Sé de Coimbra, Coimbra, Arquivo da Universidade de Coimbra, 1987.

(90) Este preciosíssimo fundo documental existente no AUC, não está ainda totalmente inventariado pelo que não nos foi possível explorá-lo exaustivamente. Contudo, usámo-lo para esclarecer quem 


\section{A Diocese de Coimbra}

Algumas especificidades relativas ao direito de apresentação obrigaram à adopção de um processo de selecção das informações a cartografar, diferente do que aconteceu com os oragos. As especificidades a que nos referimos são a existência de algumas freguesias onde o pároco era apresentado alternativamente por mais do que uma entidade e ainda o facto de, por vezes, acontecerem mudanças de padroeiro (isto principalmente no caso de padroados seculares senhoriais através de heranças, contratos, trocas, vendas, apropriação pela coroa, etc.). Estas duas situações provocam, por um lado, a possibilidade de alterações dos padroeiros com o tempo, o que, como vimos, praticamente não aconteceu com os oragos das freguesias durante os séculos XVII e XVIII. Por outro lado, levam-nos a supor que o pároco, neste ou naquele caso, ao responder aos inquéritos que lhe eram enviados podia, por vezes, indicar apenas o nome de quem o tinha apresentado e a paróquia ser de apresentação alternativa sem que isso ficasse registado.

Estas duas situações colocam problemas ao cartografarmos informações provenientes de documentos que tinham sido coligidos em épocas diferentes. Assim quando encontramos discrepâncias entre as fontes, para além de se poder estar apenas perante um simples equívoco ou erro de uma delas, isso pode também corresponder a uma alteração do padroeiro acontecida realmente, ou mesmo a uma informação incompleta de um pároco (que refere apenas quem o apresentou pessoalmente, esquecendo-se que a sua paróquia era apresentada alternativamente).

Para obviar estes problemas, optou-se por cartografar apenas os valores apresentados no Portugal Sacro-Profano. Como, maioritariamente, todas as fontes são concordantes entre si, não havia razões para duvidar que, neste aspecto, esta fosse melhor ou pior que as outras. Tem, no entanto, a grande vantagem de ser aquela para onde possuímos maior número de freguesias com informação.

tinha o direito de apresentação nas freguesias de Oliveirinha, Cernache, Assafarge, Castelões e flhavo (ver a lista de freguesias que publicamos em apêndice). Devido à enormíssima importância das suas indicações para resolver variadas questões, como a do direito de apresentação dos párocos, litígios entre «apresentadores», rendimentos eclesiásticos do clero local, mobilidade sacerdotal, etc. têm sido feitos esforços no sentido de finalizar a inventariação já iniciada. Este fundo, começou recentemente a ser estudado de forma sistemática por Francisco Azevedo Mendes, bolseiro do Instituto Nacional de Investigação Científica. 
Os cartogramas representarão o direito de apresentação dos párocos em 1758 (com alguns acrescentos em 1763), altura em que foram coligidas as informações que Niza usou e representam 350 das 369 freguesias da diocese $\left({ }^{91}\right)$. Na grande maioria dos casos, estes cartogramas são válidos para todo o século XVIII pois as outras fontes referidas confirmam os dados de Niza.

Existem freguesias da diocese não referenciadas no Portugal Sacro-Profano, para as quais temos informação proveniente de outras fontes, também no século XVIII, que optámos por não usar, para não introduzir variações cronológicas $\left({ }^{92}\right)$. Apenas para 11 freguesias não possuímos informação alguma $\left({ }^{93}\right)$.

\subsection{As entidades com direito de apresentação na Diocese de Coimbra}

Desde o Papa Alexandre III (1159-1181), que o direito de padroado se passou a limitar praticamente ao «direito de apresentação» do pároco da freguesia e, obviamente, à recepção de benefícios materiais. Os clérigos apresentados tinham no entanto que ser confirmados e empossados pelo bispo da diocese $\left({ }^{94}\right)$.

(91) Sobre a proveniência das informações coligidas por Paulo Dias de Niza para a elaboração do Portugal Sacro-Profano, ver supra a descrição das fontes utilizadas para a determinação da população diocesana.

(92) As freguesias nesta situação são as de Almaça (o Dicionário Geográfico do P. Luis Cardoso diz que é da apresentação do reitor do Colégio de S. Paulo de Coimbra). Alquerubim (do bispo de Coimbra segundo o Dicionário Geográfico), Alvoco da Várzeas (da Universidade de Coimbra segundo as informações paroquiais de 1721), Brasfemes (do Mosteiro do Lorvão segundo o Dicionário Geográfico), Cercosa (do prior dos Arcos segundo as informações paroquiais de 1721) e Moita (da apresentação da família dos Almadas segundo as informações de 1721).

(93) Estão neste caso as freguesias de Fermentelos, Ois do Bairro, Doninhas, Vila Cova do Perrinho, Ourentã, Pedrulha, Lamarosa, Carapinheira, Carragosela, Vale de Remígio e S. João de Montemor-o-Velho.

(94) Existe literatura abundante sobre o direito de padroado e sua evolução no respeitante aos aspectos histórico-jurídicos do problema, que. porém, se limita a períodos que não ultrapassam o século XIV, provavelmente por nesta altura a questão tomar em termos jurídicos o seu aspecto final (obviamente retomada no século XX com a extinção do direito de padroado). Sobre o assunto, ver duas belas sínteses que a nosso ver esclarecem os aspectos fundamentais da questão: G. Mollat, «Bénefices Ecclesiastiques», in A. Baudrillart, A. 
E esta a situação com que deparamos nos séculos XVII e XVIII. A prática estava longe de ser $100 \%$ pacífica. $\mathrm{Na}$ realidade encontram-se ainda muitos litígios a propósito de direitos de padroado $\left({ }^{95}\right)$.

de Meyer e Et. Van Cauwenbergh (dir. de), Dictionnaire d'Histoire et Géographie Ecclesiastiques, Paris, Lib. Letouzey et Ané, 1934, vol. VII, pp. 1245-1255 e H. Leclercq e F. Martroye, "Patronage». in Fernand Cabrol e Henri Leclercq (dir. de), Dictionnaire d'Archéologie Chrétienne et de Liturgie, Paris, Lib. Letouzey et Ané, 1938, vol. XIII, 2." parte, pp. 2563-2568.

Para o caso concreto de Portugal são referência fundamental, ainda que com algumas insuficiências para o período que mais nos interessa e limitando-se muito a uma perspectiva jurídica do problema, as obras de Fortunato de Almeida, História da Igreja...., vol. II, pp. 71-80 e vol. III. pp. 36-43 e de Miguel de Oliveira, As paroquias rurais portuguesas...., pp. 125-160. Nesta linha ver também os artigos «Padroados» de Armando Castro e «Padroeiros» de Rui d'Abreu Torres, in Joel Serrão (dir. de), Dicionário de História de Portugal, Lisboa, Iniciativas Editoriais, 1971, vol. III, pp. 275-76. Fugindo um pouco a esta orientação e fornecendo informações preciosas para a compreensão deste problema, numa perspectiva muito próxima da que agora nos preocupa, é o estudo de José Marques, A arquidiocese de Braga no século $X V$, Lisboa, Imprensa Nacional Casa da Moeda, 1988, pp. 1072-1095.

Sobre a forma como o provimento de benefícios na diocese de Coimbra deveria ser efectuado. de acordo com o espírito da lei, vejam-se as Constituiçoens Synodaes...., feitas por D. Afonso de Castelo Branco, Título XVII. pp. 175-182.

Sobre o caso especial dos territórios ultramarinos e dos direitos da coroa portuguesa ver Fortunato de Almeida, História da Igreja...., vol. II, pp. $241-42$ e vol. III, pp. 183-203; Joaquim Veríssimo Serrão, Livro das Igrejas e capelas do padroado dos reis de Portugal, 1574, Paris, Fundação Calouste Gulbenkian, 1971, pp. XII-XVI. O artigo «Padroado do Oriente» de António Domingos de Sousa Costa. Dicionário de Historia de Portugal, ob. cit., vol. III, pp. 272-74. Giuseppe Sorge, Il 'padroado' régio e La S. Congregazione 'de propaganda Fide' nei Secoli XIV-XVII, Bologna, ed. CLUEB, 1985.

(95) Fortunato de Almeida, refere alguns conflitos principalmente para o século XVI, mostrando como o rei $D$. Manuel chegou a intervir para tentar, por um lado, refrear os abusos cometidos principalmente por alguns padroeiros laicos, e, por outro lado, para ir juntando para si um número cada vez maior de igrejas sobre as quais passava a ter direito de padroado. Cf Fortunato de Almeida, História da Igreja...., vol. II, pp. 78-80. Miguel de Oliveira, publica um excerto de um documento régio de D. Manuel, datado de 1515, que pelo seu expressivo teor reproduzimos: «Nos soubemos como em algumas comarcas de nossos Regnos avia igrejas. que eram de Padroeiros leiguos, e que por serem muytos os Padroeiros sse ssegyam escandollos taes, per que sse oferçiam arruydo, e voltas, e ainda mortes, donde principalmente sse sseguya as Igrejas nam sserem asy bem sservidas, como devya por sserviço de nosso Senhor, e estarem de todo daneficadas, e ssem ornamentos. e outros dannos de muyto desserviço de Deos, e nosso; e por se evitarem mandamos requerer 
Nas freguesias da diocese de Coimbra, no século XVIII, segundo os dados fornecidos por Paulo Dias de Niza, a situação dos direitos de apresentação era a que o quadro n. 3 revela:

\begin{tabular}{lrr}
\multicolumn{3}{c}{ Quadro n³ } \\
\hline Apresentador & Total & Percent. \\
\hline Párocos & 73 & $20,92 \%$ \\
Conventos & 52 & $14,90 \%$ \\
Rei & 50 & $14,33 \%$ \\
Senhores seculares & 44 & $12,61 \%$ \\
Cabido & 38 & $10,89 \%$ \\
Bispo & 32 & $8,88 \%$ \\
Ordens militares & 26 & $7,45 \%$ \\
Universidade & 13 & $3,72 \%$ \\
Bispo e Papa & 10 & $2,87 \%$ \\
Colégios & 7 & $2,01 \%$ \\
Rei e cabido & 1 & $0,29 \%$ \\
Bispo e Colégio Coneg. S.to Agost.o 1 & $0,29 \%$ \\
Most. Lorvão e Papa & 1 & $0,29 \%$ \\
Bispo, Papa, Colégio S. Pedro & 1 & $0,29 \%$ \\
Rei e Religiosas de Santana & 1 & $0,29 \%$ \\
\hline Total & 350 & $100,00 \%$ \\
\hline
\end{tabular}

aos ditos Padroeiros, que nos fizessem serviço dos ditos Padroados, por que destarem em nossa mão ssera nosso Senhor sservido, e as mesmas igrejas sservidas e aproveitadas como devem, e sse escusaryam os ditos escandolos». Cf. Miguel de Oliveira, As paróquias rurais...., ob. cit., p. 144.

Também na diocese de Coimbra e para épocas mais recentes continuamos a encontrar os ecos deste problema. No ano de 1748, segundo uma sentença do Tribunal da Legacia, o cabido da Sé apresentou para prover o benefício da freguesia de Almalaguês o padre Bernardo Teixeira, dizendo ter o direito de apresentação «in solidum» desse benefício tendo logo protestado o prior e os beneficiados da colegiada de S. Pedro de Coimbra, dizendo que eram eles que tinham o direito de apresentação; ver, AUC, Colações. Um exemplo de como estes processos de colação nos permitem deslindar divergências nas fontes impressas é-nos dado na paróquia de Portunhos, que a Corografia de Costa diz ser apresentação do prior de Ançã, enquanto que - Portugal SacroProfano refere ser padroado do Marquès do Louriçal. Em 1750, o prior de Ançã e o procurador do rei embargaram a colação do padre João da Silva Redelho feita pelo Marquês de Cascais, defendendo que a paróquia. assim como Cioga do Campo, eram anexas de Ançã e por isso, indirectamente, do padroado real. Posteriormente o Marquês de Louriçal intercedeu junto do rei conseguindo a anulação da sentença de embargo. Curiosamente, em 1778, o pároco que tão atribuladamente fora colado, pede ao bispo a aceitação da sua renúncia ao benefício, pela falta de meios para subsistir. cf. AUC, Colações. 
Das 350 paróquias, 215 eram de padroado eclesiástico, 133 de padroado secular e 2 eram de alternativa eclesiástico-secular (uma entre o cabido e o rei e outra entre o rei e as religiosas de Santana). Regista-se portanto uma predominância das freguesias de padroado eclesiástico $\left({ }^{96}\right)$.

Os valores encontrados revelam que quem detinha no maior número de freguesias o direito de apresentação, eram os párocos de algumas paróquias que apresentavam o cura de igrejas anexas à sua. Estavam neste caso 73 das 350 freguesias correspondendo a cerca de $21 \%$ do total.

Era também elevado o número de paróquias em que o pároco era apresentado por conventos ou mosteiros de ordens religiosas, $52(14,8 \%)$. Esta situação era de esperar, sabendo-se da importância que alguns mosteiros tiveram na fundação de igrejas em territórios rurais durante a reconquista. $\mathrm{Na}$ região da diocese de Coimbra, as "casas" mais importantes nesta matéria eram o Mosteiro do Lorvão, que apresentava 14 paróquias, o mosteiro de Santa Cruz de Coimbra com $13\left({ }^{97}\right)$, o convento de Santa Clara de Coimbra com 8 e o convento de Jesus de Aveiro com 3. Estes números atestam bem a importância que tiveram na vida diocesana principalmente o mosteiro beneditino do Lorvão e os Crúzios de Santa Cruz.

Seguem-se-lhe em importância numérica as freguesias de padroado régio (nas quais incluímos as freguesias de apresentação da Casa do Infantado e da Casa da Rainha), com direito de apresentação em $50(14,3 \%)$ paróquias. Este facto não é de estranhar, se tivermos em atenção que por direito todos os territórios reconquistados aó infiel pelos monarcas eram automaticamente padroado seu (teoria que domina com Afonso III), ainda que, como se sabe, os monarcas depois os presenteassem principalmente a algumas ordens militares, senhores laicos e à Igreja $\left({ }^{98}\right)$. Posteriormente a política régia

(96) 0 esforço que os bispos vinham fazendo, desde o século XII, no sentido de fazer retornar a si um direito que se tinha dispersado nas mãos de vários padroeiros, libertando-se assim de certas ingerências laicas nos seus assuntos espirituais e ao mesmo tempo aumentando o seu património é referido por Miguel de Oliveira. As paróquias rurais...., pp. 146-47. Este processo não beneficiou exclusivamente nem principalmente. como veremos, a mitra, mas também os cabidos e alguns mosteiros.

(97) Não contando neste número com as 6 freguesias que eram do isento "nullius diocesis» dos Crúzios, ver supra nota 4.

(98) Sobre o assunto veja-se Miguel de Oliveira, As paróquias rurais...., pp. 132-133 e Fortunato de Almeida, História da Igreja...., vol. I, pp. 106-108 onde refere alguns conflitos existentes entre o rei 
começada com D. Manuel visou, como referimos, o aumento das paróquias de padroado régio $\left({ }^{99}\right)$. A constatação dos resultados práticos desta actuação é verificável através da comparação dos direitos de apresentação das paróquias da diocese, revelados num Censual do Bispado de Coimbra, anterior a 1523 e os apresentados por Paulo Dias de Niza $\left({ }^{100}\right)$. Das 115 paróquias comuns aos dois documentos, apura-se que 17 paróquias, que no século XVIII (1764) eram do padroado régio, não o eram ainda em data anterior a 1523, pertencendo então a nobres. Por outro lado, somente 3 , que eram do padroado real nesta última data, deixaram de o ser no século XVIII $\left({ }^{101}\right)$.

e o clero a propósito dos direitos de apresentação. Para o caso concreto da região do Baixo Mondego na diocese de Coimbra, e algumas doações de monarcas portugueses a senhores laicos ou eclesiásticos e conventos, veja-se Maria Helena Coelho, O Baixo Mondego...., vol. I, pp. 514-524.

(99) Ver supra nota 95.

(100) Os dados deste Censual cio Bispado, foram copiados em 1523 por Gaspar Velho, chanceler da correição da província da Estremadura, e encontram-se publicados por Joaquim Veríssimo Serrão, Livro das igrejas...., pp. 45-50. Esta cópia contém apenas as freguesias dos arcediagados do Vouga e Penela.

(101) As freguesias onde se constataram estas alterações são as seguintes:

\begin{tabular}{|c|c|c|}
\hline Freguesia & Censual & Portugal Sacro-Profano \\
\hline Miranda do Corvo & Mestre (?) & Rei \\
\hline Salvador de & & \\
\hline Segadães & $\begin{array}{l}\text { Mestre (?) } \\
\text { Nuno Martins Silveira }\end{array}$ & \\
\hline Ancas & Nuno Martins Silveira & \\
\hline Lamas do Vouga & Conde de Faro & Rei \\
\hline Ilhavo & $\begin{array}{l}\text { António Borges, } \\
\text { senhor de Carvalho }\end{array}$ & Rei \\
\hline Pereira & Cristovão Falcão & \\
\hline Águeda & Conde de Faro & Rei \\
\hline Arcos & $\begin{array}{l}\text { António Borges, } \\
\text { senhor de Carvalho }\end{array}$ & \\
\hline S. Miguel de Penela & Conde de Penela & Rei \\
\hline Cernache & D. António de Ataíde & Rei e cabido em alte \\
\hline Ceira & Diogo Lopes de Seque & $\begin{array}{l}\text { Rei e religiosas de } S \\
\text { tana em alternativ }\end{array}$ \\
\hline Macieira de Cambra & Conde da Feira & a do Inf \\
\hline $\begin{array}{l}\text { Cepelos } \\
\text { Castanheira do Vouga }\end{array}$ & Conde da Feira & $\begin{array}{l}\text { Casa do Infantado } \\
\text { Casa do Infantado }\end{array}$ \\
\hline Carr & Bispo & sa do Infantado \\
\hline Roge & Conde da Feira & Casa do Infantado \\
\hline
\end{tabular}

As três freguesias que deixaram de ser da apresentação do monarca foram: Espinhel, que passou para a casa de Bragança, Valongo do Vouga, que passou para o Duque de Lafões e Mira para Santa Cruz de Coimbra. 
Seguidamente, e com o direito de apresentação em 44 paróquias $(12,6 \%)$, temos um conjunto de senhores laicos. De entre eles destacam-se: o duque do Cadaval que apresentava na diocese 8 paróquias, a Casa de Bragança e o senhor de Melo com 6 cada, o duque de Lafões com 5, e o conde de Pombeiro com 4. Refira-se que é a este nível que se pode verificar uma discrepância maior entre os dados fornecidos pelo Portugal Sacro-Profano e os revelados pelas outras fontes de informação anteriores a 1758. Esta obra é compilada já depois do atentado contra D. José I, na sequência do qual foram perseguidos alguns elementos da nobreza portuguesa, a quem foram confiscados haveres e anulados títulos. Estes acontecimentos alteraram um pouco o quadro dos direitos de apresentação das paróquias da diocese. Assim, por exemplo, verifica-se que as paróquias da casa de Aveiro e do conde da Atouguia passaram para o rei $\left({ }^{102}\right)$.

$\mathrm{O}$ cabido, com quem frequentemente os bispos disputaram direitos e privilégios, fazia também a este nível sentir o seu peso e tinha inclusivamente o direito de apresentação in solidum em mais paróquias do que o próprio prelado (não contando com aquelas que o bispo apresentava alternativamente com o Papa consoante o mês da vacatura, que eram 10) ${ }^{(103)}$. Assim, na diocese de Coimbra $38(10,9 \%)$ paróguias eram apresentadas pelo cabido, enquanto o bispo apresentava $32(8,9 \%)$.

(102) Eram da casa de Aveiro antes de 1759 as freguesias de Agueda, Ancas, Lousã, Pereira e S. Miguel de Penela. Do Conde de Atouguia Cernache e Ceira. Note-se que o P. Luis Cardoso terá actualizado as informações prestadas pelos párocos em 1758, uma vez que as respostas foram na maior parte dos casos redigidas em Abril/ /Maio do dito ano tendo o atentado a D. José I ocorrido em Setembro e o processo de apuramento de culpas que se lhe seguiu, pouco tempo depois. Passaram também para o rei ao longo do século XVIII as freguesias de Arcos anteriormente dos Almadas, Miranda do Corvo, Folgosinho e Valongo do Vouga do Marquês de Arronches e Sandomil do Conde de Redondo.

(103) Refira-se contudo que na diocese de Coimbra o poder do cabido não era tão forte face ao do bispo como acontecia. por exemplo, em Braga. Sobre as relações do bispo de Coimbra com o cabido ver: Manuel Augusto Rodrigues. «D. Miguel da Anunciação e o cabido da Sé de Coimbra", Boletim do Arquivo da Universidade de Coimbra, Coimbra, 1983 , vol. V, pp. 1-53; e do mesmo autor, D. Francisco de Lemos e o cabido da Sé de Coimbra, Separata do Boletim do Arquivo da Universidade de Coimbra, Coimbra, vol. IX, 1986; Alice Correia Godinho Rodrigues, "Subsídios para o estudo da diocese de Coimbra. O bispo-conde D. João de Melo (1624-1704)», Boletim do Arquivo da Universidade de Coimbra, 1985, vol. VIII, pp. 235-339. 
Finalmente, ressalte-se a importância das paróquias de padroado das ordens militares (cujo direito de apresentação dos párocos estava nas mãos do rei enquanto superior do tribunal da mesa da consciência das referidas ordens, à excepção da ordem de Malta) com 26 paróquias $(7,4 \%)$ e da Universidade de Coimbra com $13(3,7 \%)\left({ }^{104}\right)$. A maioria das freguesias da diocese apresentadas por ordens militares eram da ordem de Cristo (16) e da ordem de Aviz (7).

As restantes freguesias eram apresentadas por um vasto leque de entidades. cujo peso relativo era pequeno, como se pode constatar pela leitura do quadro n. 3 .

\subsection{Distribuição espacial dos direitos de padroado}

Vejamos agora como se distribuíam espacialmente estes valores, através da leitura dos cartogramas n. ${ }^{\text {s }} 13$ a 20.

Repare-se desde já, que em todos eles se nota uma tendência muito clara para a constituição de certas "zonas» ou "manchas", que nos levam a constatar a existência de territórios no interior da diocese, onde este ou aquele poder fazia sentir a sua acção mais eficazmente $\left(^{105}\right)$.

0 cartograma n. ${ }^{0} 13$ representa as paróquias da apresentação de párocos de igrejas e deixa perceber com extrema nitidez o que acabámos de referir. Como se pode verificar, a grande parte das paróquias desta apresentação tem como característica fundamental estarem situadas na parte Leste da diocese, com especial incidência no arcediagado de Seia. Não será talvez difícil entender esta situação, se se tiver presente que destas 73 freguesias só uma (Cumieira no arce-

(104) A administração das três ordens militares (Aviz, Santiago e Cristo) foi concedida primeiramente a título pessoal a D. Manuel pela bula "Constanti fide» de 1516 . A partir de 1551 , já no reinado de D. João III, o Papa Júlio III, concedeu ao rei e a todos os seus sucessores a administração das três ordens, pela bula "Praeclara charissimi». Cf. Fortunato de Almeida, História da Igreja...., vol. II, p. 219. A Ordem de Malta gozava de um estatuto especial bastante privilegiado. A este respeito veia-se: António de Oliveira, "A violência do poder dos cavaleiros de S. João no período Filipino", in Estudos e ensaios em homenagem a Vitorino Magalhães Godinho, Lisboa, Liv. Sá da Costa, 1988. pp. 263-276.

(105) 0 exercício destes poderes por parte de certas entidades em determinadas zonas do país radicava na própria concepção de território no Antigo Regime. Sobre o assunto ver António Manuel Hespanha, As vésperas do Leviathan...., vol. I, pp. 113-162, e para uma apreciação detalhada terra a terra, 0 anexo 1 do vol. II. 


\section{A Diocese de Coimbra}

diagado de Penela), não era um curato $\left({ }^{106}\right)$. A criação destes curatos era o resultado da necessidade de fragmentação de uma circunscrição paroquial devido ao seu crescimento populacional ou à distância entre os vários lugares que a compunham ou, inclusivamente, às dificuldades de deslocação no seu interior por ausência de caminhos. Nestes casos a freguesia cindia-se dando origem a uma freguesia mãe e a outra sua anexa. $\mathrm{O}$ pároco da anexa era com regularidade designado por "cura» e apresentado pelo pároco da freguesia mãe. Isto deixa subentender a sua pobreza, uma vez que os rendimentos dos curas eram normalmente muito exíguos, devido à pobreza dos lugares onde exerciam o seu mister pastoral e os próprios curas disso frequentemente se queixavam $\left({ }^{107}\right)$. Não é por isso de estranhar que grande parte destas freguesias se situem na região montanhosa, pobre e de difícil acesso, que eram as serranias da Estrela, Açor e Lousã, que é. como vimos também, uma região que conhece dos mais significativos crescimentos populacionais da diocese durante o século XVIII $\left({ }^{108}\right)$.

As freguesias de apresentação de conventos ou mosteiros encontram-se sobretudo ao longo da linha do Mondego, na faixa costeira ocidental da diocese e num núcleo situado no Sul do arcediagado de Penela, ou seja incidem sobretudo nos arcediagados de Vouga e de Penela (em Seia apenas 3 paróquias estavam nesta situação), como se pode ver no cartograma $\mathrm{n}^{\circ} 14$.

Uma aproximação microscópica desta distribuição permite ainda detectar a formação de regiões da apresentação

(108) Note-se contudo que isto não quer dizer que todos os curatos fossem da apresentação de párocos. Havia em toda a diocese pelo menos 62 curatos que não eram apresentados por párocos.

(107) Esta pobreza e mesmo as dificuldades de subsistência dos curas de algumas freguesias pode ser comprovada pelas respostas que muitos deles deram ao inquérito paroquial que circulou na diocese em 1721.

(108) Curiosamente numa lista de igrejas taxadas em 1359 na diocese de Coimbra, correspondendo na maior parte dos casos a igrejas que eram sedes de freguesia, só se encontraram 4 das 73 que em 1758 eram curatos da apresentação de párocos e essas quatro (Macieira de Alcoba, Pinhanços, Travancinha e Valezim) renderam dos quantitativos mais baixos de toda a colecta. A lista a que nos referimos foi publicada por Fortunato de Almeida na sua História da Igreja...., vol. IV, pp. 122-127 e o seu objectivo era permitir ao papa João XXII saber em quanto orçavam todas as rendas eclesiásticas do reino de Portugal (supõe-se portanto que cobriria a maioria das igrejas paroquiais então existentes). para poder auxiliar o monarca português D. Dinis na guerra contra os Mouros, concedendo-lhe a décima das ditas rendas durante um período de três anos. 
dos mosteiros ou conventos mais importantes e que acima já referenciámos. Assim, o mosteiro do Lorvão tinha as suas paróquias de apresentação em três pólos distintos: um próximo de Aveiro e composto pelas freguesias de Esgueira, Salreu e Cacia; outro na zona circundante da sua casa mãe, composto pelas freguesias de Foz de Arouce, Torre de Vilela, Lorvão, Souselas, Figueira de Lorvão, Serpins e Botão; e finalmente um núcleo no sul do arcediagado de Penela constituído por Abiul, Almoster e Santiago da Guarda. Em relação aos cónegos de Santa Cruz, verifica-se a existência dum núcleo nas margens do Mondego, já próximo da sua foz e na faixa costeira ocidental da diocese, com as freguesias de Brenha, Redondos, Ferreira-a-Nova, Verride, Quiaios, Mira e Tocha (esta era do isento como já referimos) e depois uma dispersão das outras freguesias da sua apresentação por toda a diocese $\left({ }^{109}\right)$.

As paróquias de padroado régio (incluindo como já dissemos as casas do Infantado e da Rainha) encontram-se disseminadas por toda a diocese, mas, apesar disso, podem-se detectar três regiões onde o rei concentrava muitas freguesias da sua apresentação, como se pode ver na carta n. ${ }^{\circ} 15$. Uma situa-se no limite Norte do Arcediagado de Vouga, outra na metade oriental do arcediagado de Seia e finalmente uma outra no arcediagado de Penela.

As paróquias de apresentação de senhores laicos localizam-se sobretudo nos arcediagados de Vouga e Seia (em Penela apenas 4 freguesias estão nesta situação), como mostra o cartograma n. $16\left(^{110}\right)$. Este mapa permite ainda verificar quais as zonas de influência mais acentuada de algumas casas senhoriais. O Duque de Cadaval tinha na diocese dois focos de influência muito claros; um em torno de Montemor-o-Ve-

(109) Desde cedo os Crúzios quiseram povoar e tirar proveito dos territórios que possuíam na Foz do Mondego e costa litoral do arcediagado de Vouga. Nesse sentido aliciavam-se os futuros colonos com facilidades e algumas doações. Sobre o assunto ver Maria Helena Coelho, O Baixo Mondego...., ob. cit., vol. I, pp. 43-53.

(110) Esta distribuição da zona de maior implantação dos direitos de apresentação de casas senhoriais laicas no século XVIII, nos arcediagados de Seia e Vouga, é mais uma manifestação de estruturas criadas durante a reconquista. Segundo José Mattoso, durante os séculos XII e XIII, os territórios desta região foram sendo ocupados por senhores laicos quer de linhagens estabelecidas, oriundas do Norte de Portugal, quer de novas famílias que têm a sua origem em cavaleiros que de alguma forma se distinguiram na Reconquista e a quem os monarcas portugueses presentearam domínios. Cf. José Mattoso, A nobreza medieval portuguesa. A família e o poder, Lisboa, Editorial Estampa. 1987, pp. 317-321. 


\section{A Diocese de Coimbra}

lho, com as freguesias de S. Miguel e Madalena da dita vila, Tentúgal, Anobra e Vila Nova de Anços; e outro, no limite Sudeste do arcediagado de Vouga composto por Sobral, Mortágua e Marmeleira. Por sua vez, a casa de Bragança possuía um núcleo no coração do arcediagado de Vouga de que faziam parte as freguesias de Oliveira do Bairro, Ois da Ribeira, Requeixo, Eixo, Espinhel e Belazaima do Chão. Finalmente, os senhores de Melo apresentavam em torno da freguesia com o mesmo nome, no extremo oriental do arcediagado de Seia: para além de Melo, as igrejas paroquiais de Vila Cortês da Serra, Meruge, Nabainhos, Arcozelo e Nabais ( ${ }^{111}$ ).

Um dos exemplos mais sugestivos da constituição de zonas de influência de que temos vindo a falar é o das paróquias de apresentação do cabido. Ao olhar-se para o cartograma n..$^{\circ}$, resulta logo essa impressão, dada pela existência de cinco grandes pólos de aglutinação, que contudo se estendem por toda a diocese, mostrando deste modo o largo espectro da influência e da origem dos rendimentos dos capitulares da Sé.

As paróquias de apresentação do bispo de Coimbra (cartograma n. 18), conhecem também uma distribuição geográfica característica, ao agruparem-se em três núcleos distintos. Um ao longo do vale do Mondego, desde Coimbra até à Figueira da Foz, com mais incidência na margem esquerda do dito rio e com um prolongamento para Norte, a partir de Montemor-o-Velho até Arazede; outro, em torno da vila de Coja no arcediagado de Seia e um terceiro, mais pequeno, no extremo Sudeste do arcediagado de Vouga formado por S. Joaninho, Couto do Mosteiro e Santa Comba Dão.

O cartograma n. 19 mostra as paróquias de apresentação das ordens militares e revela uma grande incidência destas no arcediagado de Penela, devida fundamentalmente aos territórios que eram da apresentação da Ordem de Cristo (Templários), que tinha a sua «sede» em Tomar (já fora da diocese). Em todo o território do arcediagado, a única freguesia de apresentação das ordens militares que não era da Ordem de Cristo, era Santa Eufémia de Penela, da apresentação da Ordem de Aviz. No arcediagado de Vouga apenas a Ordem de Aviz apresentava, precisamente as quatro freguesias

(111) A importância da casa de Melo nesta região é secular pois já desde o século XII, esta família, cuja origem se situava na zona de Entre Douro e Minho, se tinha aqui estabelecido, sendo uma das casas senhoriais mais preponderantes da Beira portuguesa, como diz José Mattoso, in A nobreza medieval...., pp. 323-26. 
da vila de Aveiro (Vera Cruz, Espírito Santo, S. Miguel e Nossa Senhora da Apresentação). No arcediagado de Seia situavam-se as duas únicas freguesias da Ordem de Malta: Oliveira do Hospital e Figueiró da Serra.

Finalmente vejamos o caso das freguesias de apresentação da Universidade através da carta $n .^{\circ} 20$, que mostra como elas se distribuíam dispersivamente por todos os arcediagados da diocese, juntando-se apenas em grupos de duas no arcediagado de Penela (Louriçal e Mata Mourisca) e no de Vouga (Avelãs de Cima e Aguada de Cima).

O quadro da distribuição geográfica dos direitos de apresentação das paróquias que acabámos de expôr, se nos revela, por um lado, a tendência para a constituição de «zonas de influência" deste ou daquele poder, como temos vindo a verificar, por outro lado, deixa transparecer a ideia de uma grande estabilidade ao longo do tempo. Isto é, se em relação às paróquias de apresentação nobre notamos algumas oscilações, pelo facto do poder senhorial estar por natureza mais sujeito à conjuntura política (notando-se, porém, algumas permanências de que o exemplo da casa de Melo é significativo), na maior parte dos casos o direito de apresentação raras vezes mudava de mãos. Os exemplos de Santa Cruz, bispo, cabido, ordens militares, etc., são, a este respeito, suficientemente sugestivos.

Sublinhe-se o facto de o bispo apresentar directamente um número reduzido de paróquias, apesar de, por via indirecta, poder exercer em teoria um certo controle no clero diocesano, ao não confirmar as apresentações indicadas pelos padroeiros das paróquias. As visitas pastorais, eram, neste contexto, um instrumento importantíssimo para os prelados averiguarem o desempenho dum clero paroquial que, na grande maioria dos casos, não era da sua escolha.

\section{Títulos do clero local}

\subsection{Os títulos dos párocos: Fontes e método utilizado para o seu estabelecimento}

Por título do clero local, entendemos a forma porque era comummente designado o pároco que dirigia os ofícios divinos numa paróquia.

Os mapas agora apresentados foram criados usando procedimentos idênticos àqueles que serviram para elaborar 


\section{A Diocese de Coimbra}

os cartogramas dos oragos e dos direitos de apresentação das paróquias. Utilizaram-se, neste caso, para além das informações paroquiais de 1721, a Corografia Portugueza de A. Costa, o Dicionário Geográfico de Luís Cardoso e o Portugal Sacro-Profano de Paulo Dias de Niza.

As fontes são, mais uma vez, concordantes na esmagadora maioria dos casos. Das 364 freguesias para as quais foi possível obter informações a este respeito, só 30 manifestavam discrepâncias entre duas ou mais fontes, o que corresponde a uma percentagem de cerca de $8 \%$. Em relação a estas 30 freguesias foi ainda possível chegar a um resultado válido em 17 casos. Considerou-se válida uma designação, quando existindo 3 ou 4 fontes de informação para uma mesma paróquia, 2 ou 3 delas eram concordantes entre si ${ }^{(112)}$. Foi assim possível, determinar como era designado o pároco da freguesia em 351 das 369 freguesias da diocese.

\subsection{Significado das várias apelações: estado da questão $e$ particularidades regionais}

Pouco se sabe actualmente sobre o verdadeiro significado, origem e implantação geográfica das várias designações porque eram nomeados os párocos das freguesias $\left.{ }^{(113}\right)$. É usual afirmar-se que no Norte de Portugal a designação de «abade» é popularmente dada a qualquer pároco, ao passo que no Sul é mais frequente o epíteto de "prior». Esta distinção resultaria da maior influência exercida a Norte pelas ordens monásticas e a Sul pelas Ordens militares. Na diocese de Braga, «abade» indicia a origem beneditina de uma paró-

(112) Deste modo, foi possível determinar como era designado o pároco nas freguesias de: Arrifana de Poiares, Nossa Senhora da Apresentação de Aveiro, S. Miguel de Aveiro, Cioga do Campo, Coentral, Coja. Espinhal, Góis, Loriga, Marmeleira, Mesquitela, Alcaçova de Montemor-o-Velho, Paços da Serra, Penacova, Portunhos, S. Martinho de Seia e Santa Eulália.

(113) Para além das poucas linhas que Miguel de Oliveira escreve sobre o assunto (referindo-se aí apenas a duas obras que aludem à questão), do estudo do Padre Domingos Moreira (onde se apresentam documentos de suma importância para a resolução de algumas destas questões com especial destaque para a designação de "cura» e formação de «curatos») e dos textos obviamente insuficientes que surgem neste ou naquele dicionário, pensamos que a questão está longe de ficar suficientemente esclarecida. Cf. Miguel de Oliveira. As paróquias rurais...., pp. 149-151; Domingos Moreira, ob. cit., pp. 77 e ss. Fr. Gabriel de Sousa, Abade em Portugal, in Alberto Banha de Andrade (dir. de), in Dicionário de História da Igreja em Portugal, Lisboa, Editorial Resistência, 1980, vol. I, pp. 1-3 e na mesma obra, António Leite, Benefício Eclesiástico, vol. II, pp. 408-418. 
quia, "prior» aponta para uma influência dos Cónegos Regrantes de Santo Agostinho e "reitor» supõe uma ligação umbilical a uma abadia ou priorado $\left.{ }^{114}\right)$. É também aceite que "abades» e "priores» estariam no topo da carreira eclesiástica paroquial ao receberem directamente os dízimos das suas paróquias, enquanto que "curas», "reitores» e "vigários», teriam uma situação financeira mais precária, auferindo uma côngrua $\left(^{115}\right)$.

Não nos propômos aqui resolver esta delicada questão, mas tão somente constatar como se distribuíam no território diocesano essas diferentes formas de nomeação $\left({ }^{116}\right)$.

As informações de que dispomos indicam-nos das 351 paróquias para as quais nos foi possível coligir informações, em $135(37 \%)$ o pároco recebia a designação de "cura", em $129(35 \%)$ a de "prior», em $83(23 \%)$ a de «vigário» e em 4 (1\%) de «reitor».

E importante notar a ausência da designação de «abade», confirmando assim a ideia de uma implantação deste termo sobretudo a Norte do Douro, e a pobreza das referências ao título de "reitor». Em relação a este segundo termo, é provável que tal se deva ao facto de haver uma relativa indiferenciação entre esta designação e a de vigário. Ao compulsarmos as Constituicões Sinodais do bispado esta indiferenciação afigura-se evidente $\left({ }^{117}\right)$. Por outro lado, e em abono desta

(114) Cf. Miguel de Oliveira, As paróquias rurais...., p. 150.

(115) A este respeito ver por exemplo, Fernando de Sousa, "O clero da diocese do Porto no tempo das cortes constituintes", Revista de História, n. 2, 1979, p. 253 e José Capela, "Os rendimentos dos párocos do concelho e arciprestado de Barcelos nos fins do Antigo Regime e durante o século XIX», Barcellos-Revista, 2 (1), 1984, pp. 2-9.

(116) Para uma compreensão total do problema era necessário, entre outras coisas, possuir uma ideia de como se distribuíam os rendimentos dos párocos das freguesias, informação que de momento ainda não temos completamente tratada.

(117) Assim, por exemplo, no título XII das Constituições, diz-se: «Mandamos a todos os Priores, Reytores, ou Vigarios perpetuos, e removiveis deste nosso Bispado, que fação a dita residencia pessoal como são obrigados....” (sublinhado nosso). Cf. Constituições Synodaes...., p. 95. Tratando ainda da obrigatoriedade de residência dos párocos diz o texto das Constituições: «....E os nossos visitadores perguntarão na Visitação, se os Priores e Reytores o cumprem assim, e dos que acharem que nisto são descuydados, e não fazem o que devem, fará sumário para se proceder contra elles, e serem castigados conforme as suas culpas.

E se algum Prior, ou Vigario, não tendo coadjutor ou Cura, adoecer de doença prolongada, será obrigado a encomendar a sua igreja a algum Sacerdote idoneo, ....». Cf. ob. cit., p. 98 (sublinhados 


\section{A Diocese de Coimbra}

ideia, algumas das incongruências verificadas entre as fontes utilizadas para o estabelecimento destes valores, que acima referimos, radicavam precisamente na referência a freguesias cujo título do pároco era para uma fonte «vigário» e para outra "reitor» $\left({ }^{118}\right)$.

Os curatos e a respectiva designação de "cura» constituem assim a designação mais comum, seguindo-se-lhe os priorados e depois as vigararias e reitorias.

\subsection{Variação dos títulos do clero local no espaço diocesano}

Os cartogramas n. ${ }^{\text {os }} 21$ a 23 reportam-se aos «títulos» do clero local mais frequentes na diocese.

0 n. 21 mostra como se distribuíam os curatos no território diocesano e permite constatar a existência de núcleos de paróquias onde a denominação de cura era atribuída ao pároco local. O bloco mais consistente situa-se numa faixa que se estende longitudinalmente ao longo do limite Sul do arcediagado de Seia. Note-se que esta região já tinha sido salientada como uma daquelas onde existia uma densidade populacional mais baixa e paralelamente uma taxa de crescimento elevado, uma zona onde os oragos de invocação a Nossa Senhora eram frequentes e onde os direitos de apresentação das paróquias estavam usualmente na mão de párocos.

$\mathrm{Na}$ metade Norte do arcediagado de Penela encontramos também dois núcleos de concentração destes curatos. No arcediagado do Vouga é flagrante uma linha que se vai desenvolvendo ao longo da parte oriental da serra do Bussaco até ao início do maciço Caramulano, principiando na freguesia de Oliveira do Cunhedo e terminando em Agadão. Todos estes núcleos têm em comum o facto de se situarem em serras. O primeiro a que nos referimos, com freguesias situadas na Estrela e Açor, os segundos na serra da Lousã e Sicó e finalmente os últimos raiando o Bussaco e subindo ao Caramulo.

nossos). Repare-se como no mesmo contexto num caso se usou «reitor sem qualquer referência a "vigário» e noutro se fez o inverso.

Todo este título das Constituições, relativo à residência de «priores», "reitores» e "curas» está repleto da utilização ambígua das denominações de «reitor» e "vigário». Saliente-se ainda que o nome do Título XII das constituições é «Dos priores. Reytores e Curas....» não se fazendo menção nele a figura do "vigário» como sendo distinta, o que não teria a menor lógica se não se entendesse por «vigário» ou «reitor» uma figura com funções idênticas.

(118) São exemplo do que acabamos de dizer Castelōes, Góis, Loriga, Mesquitela, Penalva de Alva, S. João de Loure e Sebal. 


\section{Revista de História das Ideias}

Esta particularidade é interessante e permite em certa medida entender a pobreza destes curatos, bem como verificar que estas freguesias corresponderam, decerto, a um povoamento mais tardio. Se olharmos atentamente para uma pormenorizada carta orográfica, verificamos que normalmente estas freguesias vão aparecendo ao longo de rios e ribeiras, na direcção das suas nascentes $\left({ }^{119}\right)$.

Outro núcleo de curatos, que contudo não se enquadra nas facetas dos anteriores, existe ainda no arcediagado do Vouga (Vagos, Covão do Lobo, Covões, Pocariça, Ourentã e Cantanhede). Esta região, ao contrário das que referimos atrás, é de baixa altitude.

Todos estes curatos eram na sua maioria de apresentação eclesiástica, com destaque para os que eram apresentados por párocos (66 dos 135).

O mapa $n .^{\circ} 22$ esclarece a geografia dos priorados e deixa entender numa primeira abordagem, como estes tendem a aumentar no sentido Sul/Norte. Tal é evidente, pois excluindo uma pequena mancha situada no limite Sul do arcediagado de Penela, a maioria dos outros priorados situam-se na metade Norte do arcediagado de Seia e no arcediagado de Vouga.

Se sobrepusessemos este mapa aos que representam as freguesias de apresentação dos senhores laicos e do rei (respectivamente n. 15 e 16), verificaríamos várias «manchas» coincidentes. $\mathrm{Na}$ realidade $56 \%$ dos priorados da diocese eram da apresentação do rei e senhores laicos, durante o século XVIII. Mas, mais significativo do que este valor, é o facto de que, das 44 paróquias de apresentação de senhores laicos, 35 (cerca de $80 \%$ ) eram priorados, o mesmo se passando com 37 das $50(74 \%)$ de apresentação régia.

Vejamos finalmente o caso das vigararias, através da análise do cartograma n..$^{\circ}$ 23. Também aqui se nota uma disposição muito clara, com um aumento da designaçăo de vigário de Norte para Sul e igualmente um crescimento do interior para o litoral da diocese.

Não pode deixar de ser notada uma semelhança entre este mapa e o que descreve a distribuição das freguesias de apresentação das ordens militares (cartograma $n .^{\circ} 19$ ), principalmente no que diz respeito à grande mancha que cobre grande parte da metade Ocidental do arcediagado de Penela.

(119) Isto é particularmente evidente, por exemplo, em Góis e Coja, cujos párocos apresentam uma série de curas de paróquias progressivamente mais altas na serra. Assim o vigário de Góis apresentava os curas de Celavisa, Cadafaz, e Colmeal, e o de Coja, os curas de Cerdeira, Benfeita e Teixeira. 


\section{A Diocese de Coimbra}

Efectivamente, esta região corresponde sensivelmente aos territórios da apresentação da Ordem de Cristo. Aliás, cerca de $70 \%$ das freguesias de apresentação das Ordens militares eram vigararias, dado que não deve ser omitido. Esta indicação deixa no ar algumas dúvidas quanto à tese, relativamente corrente, de que no Sul a designação de "prior» substitui a de "abade», em virtude da maior influência das ordens militares nesta parte do território. Tal seria a nosso ver verdadeiro, se as paróquias de padroado das ordens militares fossem priorados na sua maioria, o que não acontece, pelo menos na diocese de Coimbra.

Outro indicador a ter em conta é o facto de muitas destas vigararias serem da apresentação de conventos ou mosteiros, 21 mais precisamente.

Resulta da leitura destes mapas, que existia na diocese uma disposição expressiva dos títulos do clero local, que se pauta pelas seguintes linhas: proeminência dos curas nas serras (muito provavelmente em paróquias de criação mais tardia), aumento dos "priores» no sentido Sul/Norte, ao contrário do que se passa com os vigários que tendem a crescer numericamente de Norte para Sul.

Esta geografia revela também muitas sintonias com os direitos de apresentação das freguesias, o que deixa indiciar ligações estreitas entre o título do clero local e a fundação da paróquia. Neste sentido vimos como os curatos eram na sua quase totalidade de apresentação eclesiástica (com destaque para os párocos), que terras de padroado régio ou de senhorios laicos tinham normalmente um prior e, finalmente, como grande parte das freguesias de apresentação das ordens militares e muitas de conventos ou mosteiros tinham como titular um vigário.

\section{Conclusão}

Os resultados aqui apresentados, reafirmam, numa multiplicidade de aspectos, alguns pontos que queremos realçar.

Em primeiro lugar a existência de assimetrias regionais. Com efeito certas regiões reaparecem em cada mapa com valores que as individualizam. O litoral, zona de baixa densidade mas elevada população, onde a existência de grandes áreas ainda sub-aproveitadas sustenta um crescimento populacional significativo, que ultrapassa decerto, em ambos os sentidos, o século XVIII que aqui descrevemos. Esta longa 
faixa de beira-mar está ligada fortemente, sobretudo a Norte do Mondego, ao Mosteiro de Santa Cruz $\left({ }^{120}\right)$. E cortada pela foz do Vouga e do Mondego, no fim dos respectivos vales densamente povoados.

Opostas ao litoral temos as serras do interior constituídas pela Estrela, Açôr, Lousã, Sicó, Bussaco, Caramulo e Arada. Esta zona de baixa densidade e reduzidos contingentes humanos, vai crescendo, numa tendência semelhante ao litoral, mas em escala reduzida. Zona de curatos, possivelmente de criação mais tardia do que as paróquias mais ricas dos vales, cujos párocos retinham o direito de apresentação nas terras altas. Zona de forte implantação das dedicações a Nossa Senhora, sobretudo nas serras do arcediagado de Seia e de Penela, reflexo indirecto de um povoamento tardio.

Os vales do Vouga e do Mondego sobressaiem pela elevadíssima concentração humana, desenhados claramente pelas zonas escuras do cartograma da densidade populacional. Terras férteis, onde se concentram no primeiro caso terras de apresentação do rei e de senhores laicos e no segundo freguesias de padroado episcopal e de mosteiros.

Dois factores estruturais sobressaem com nitidez deste quadro. Em primeiro lugar, o relevo e os solos, condicionantes primordiais da ocupação humana. $\mathrm{E}$ o seu peso que provoca a extraordinária permanência entre as cartas de densidade populacional do século XVIII e a da primeira metade do século XX. Em segundo lugar, as múltiplas marcas do tempo em que aqui passava uma das importantes fronteiras da reconquista cristã. A Norte do Mondego os oragos reflectem os mais antigos cultos da cristandade peninsular, substituídos progressivamente a Sul pelas novas devoções. No Norte da diocese, não longe do berço do regime senhorial português, encontramos ainda no século XVIII o grosso das paróquias apresentadas por nobres. No extremo Sul, sãa as ordens militares que retêm ainda o poder que lhes foi doado em troca da tarefa que desempenharam ao proteger as fronteiras mais ameaçadas.

Paradoxalmente, tendo partido à procura da especificidade de um espaço setecentista, encontrámos as marcas de

(120) Para a evolução do litoral ver: Fernando Castelo Branco, Alguns aspectos da evolução do litoral português, separata do Boletim da Sociedade de Geografia, Julho-Setembro de 1957 e Alfredo Fernandes Martins, «Configuração do litoral português no último quartel do século XIV. Apostila um mapa», Biblos, XXII, 1946. 


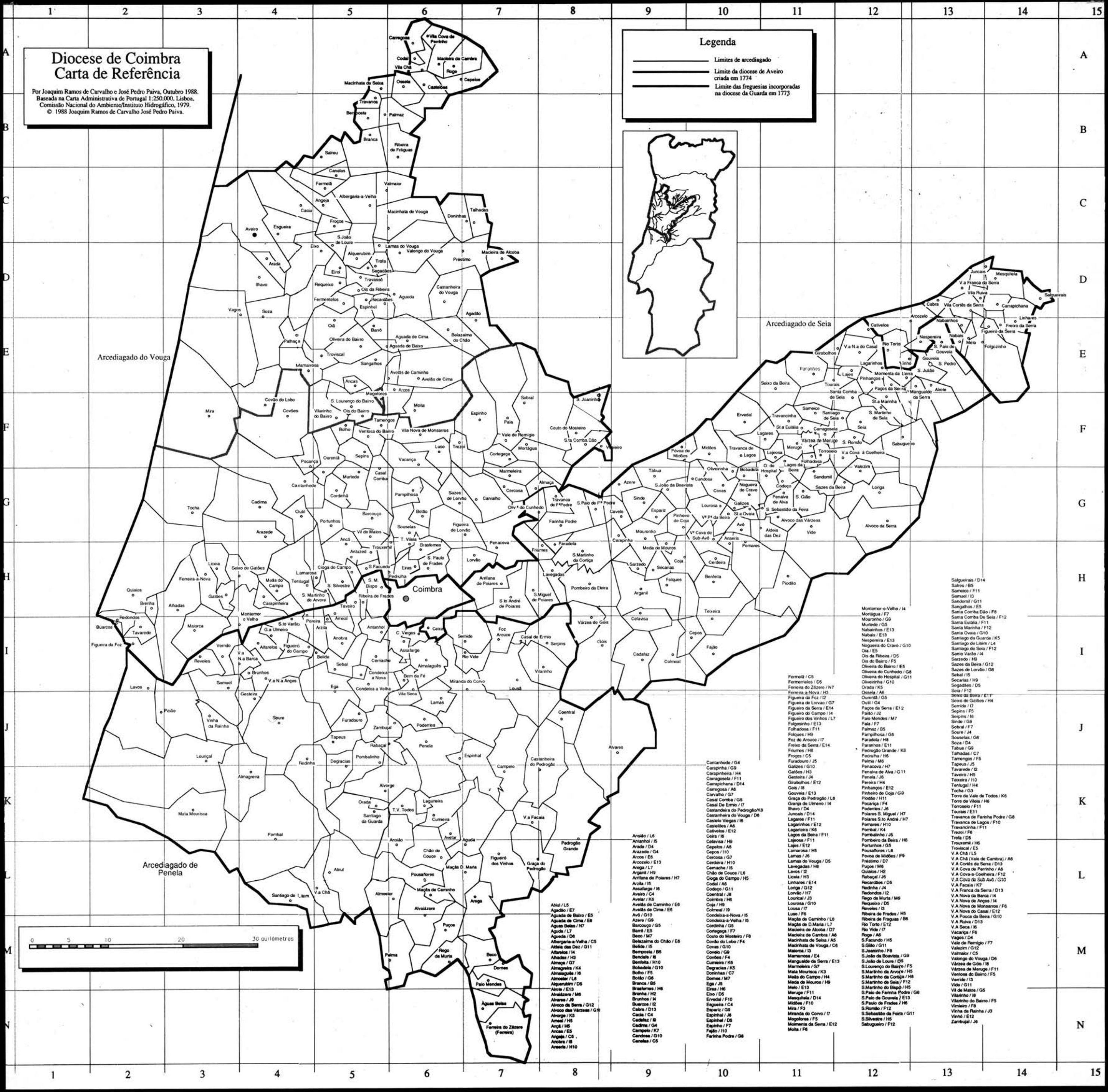




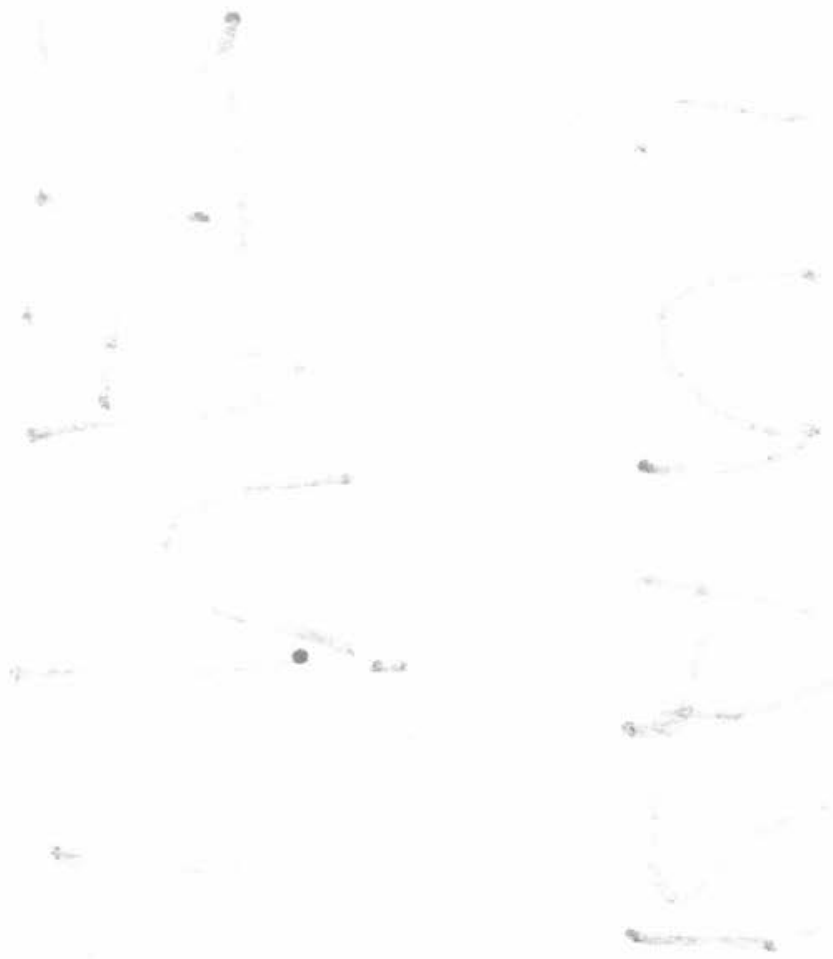




\section{A Diocese de Coimbra}

estruturas plurisseculares que nos remeteram constantemente para os primórdios da nacionalidade e que se continuam ainda a projectar no presente.

\section{Agradecimentos}

Pela variedade da informação tratada, tivemos que tocar aspectos cuja complexidade frequentemente exigiu competências que nos ultrapassavam. Assim, estamos em dívida para com inúmeras pessoas que, de maneiras variadas, nos forneceram precioso auxílio. Francisco Azevedo Mendes prestou uma contribuição que não poderemos agradecer suficientemente. Desde o auxílio na recolha de fontes, à paciência com que nos ouviu expôr, inúmeras vezes, os pequenos avanços que a nossa investigação ia conseguindo, até à leitura das primeiras versões deste escrito, sempre forneceu valiosas sugestões que nos foram preciosas. A Dr. ${ }^{a}$ Guilhermina Mota teve a bondade de reler o capítulo sobre a população e contribuiu muito para o que eventualmente nele exista de cuidado metodológico. A Dr. ${ }^{a}$ Gabriela Salgueiro esclareceu-nos, pacientemente, sobre técnicas estatísticas de análise espacial. O Dr. António Tavares Lopes elaborou graciosamente um programa de cálculo de médias móveis geográficas e de coeficientes de auto-correlação espacial, que teve um importante papel no trabalho de análise de alguns dos cartogramas aqui apresentados. O Dr. Pedro França resolveu-nos inúmeras questões relacionadas com as famílias nobres portuguesas no século XVIII, assunto que conhece como poucos. Inúmeras pessoas forneceram ainda indicações ou esclarecimentos sobre assuntos vários que nos foram muito úteis: Dr. $^{\mathrm{a}}$ Ana Cristina Araújo, Dr. ${ }^{\mathbf{a}}$ Ana Maria Bandeira, Doutora Maria Helena Coelho, Dr. ${ }^{a}$ Margarida Neto e o Dr. Rui Cascão. Ao Professor Doutor Manuel Augusto Rodrigues vai o nosso agradecimento final pela sua orientação, encorajamento e entusiasmo em tudo quanto diz respeito à história religiosa da diocese de Coimbra. Obviamente, todas as deficiências que posam ser resultado da utilização que fizemos de tão valiosas contribuições são da nossa inteira responsabilidade. 


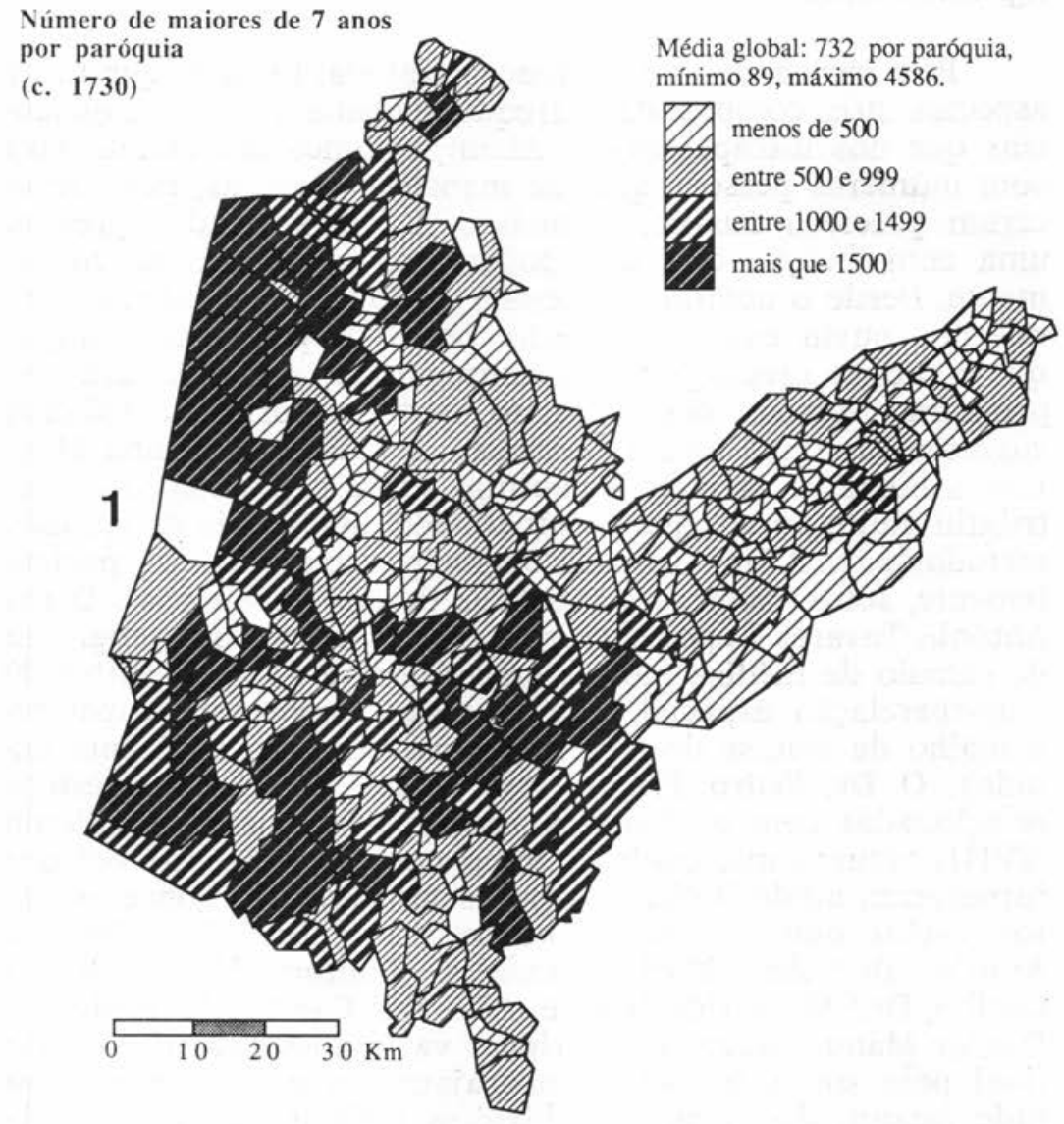




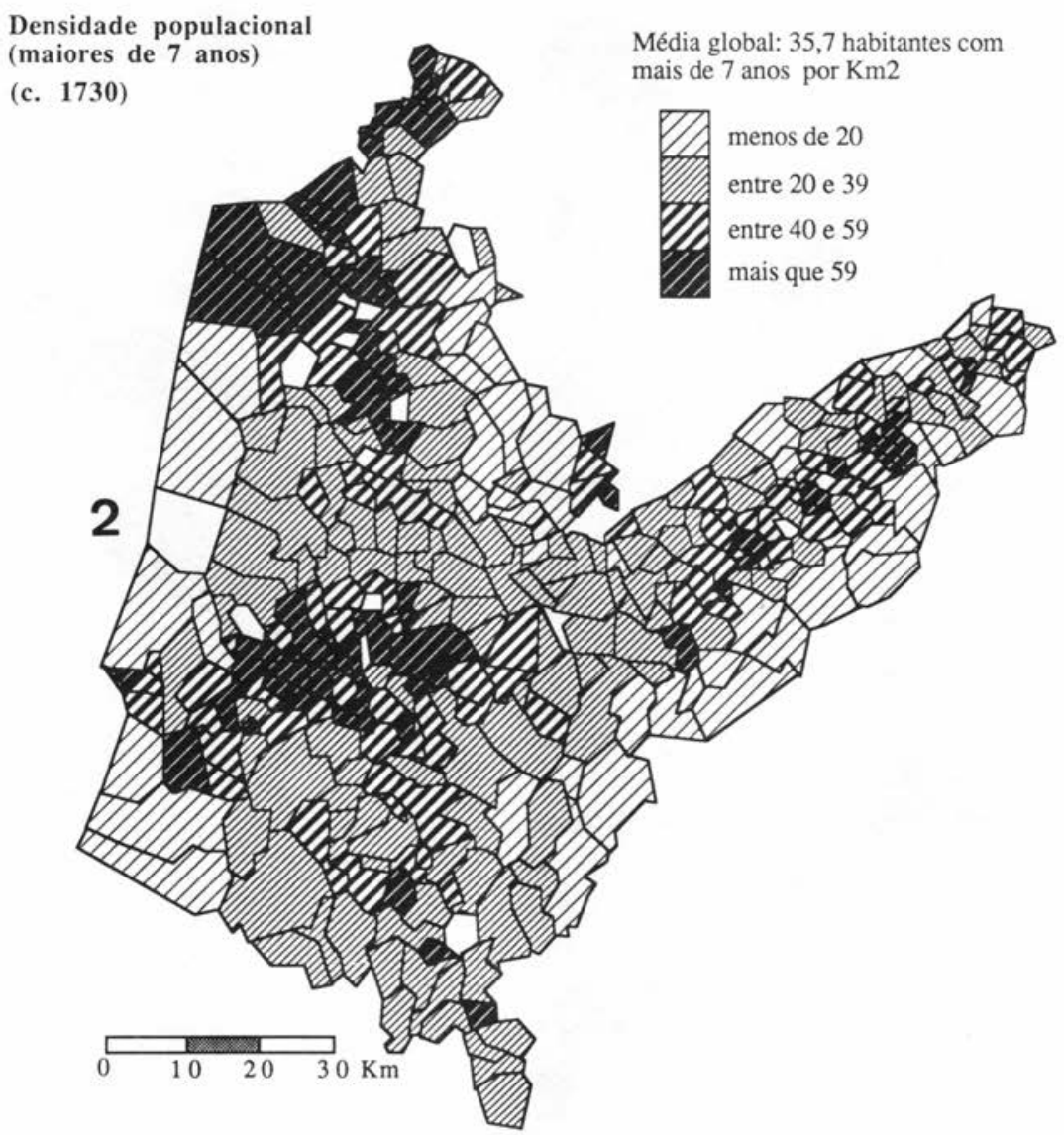




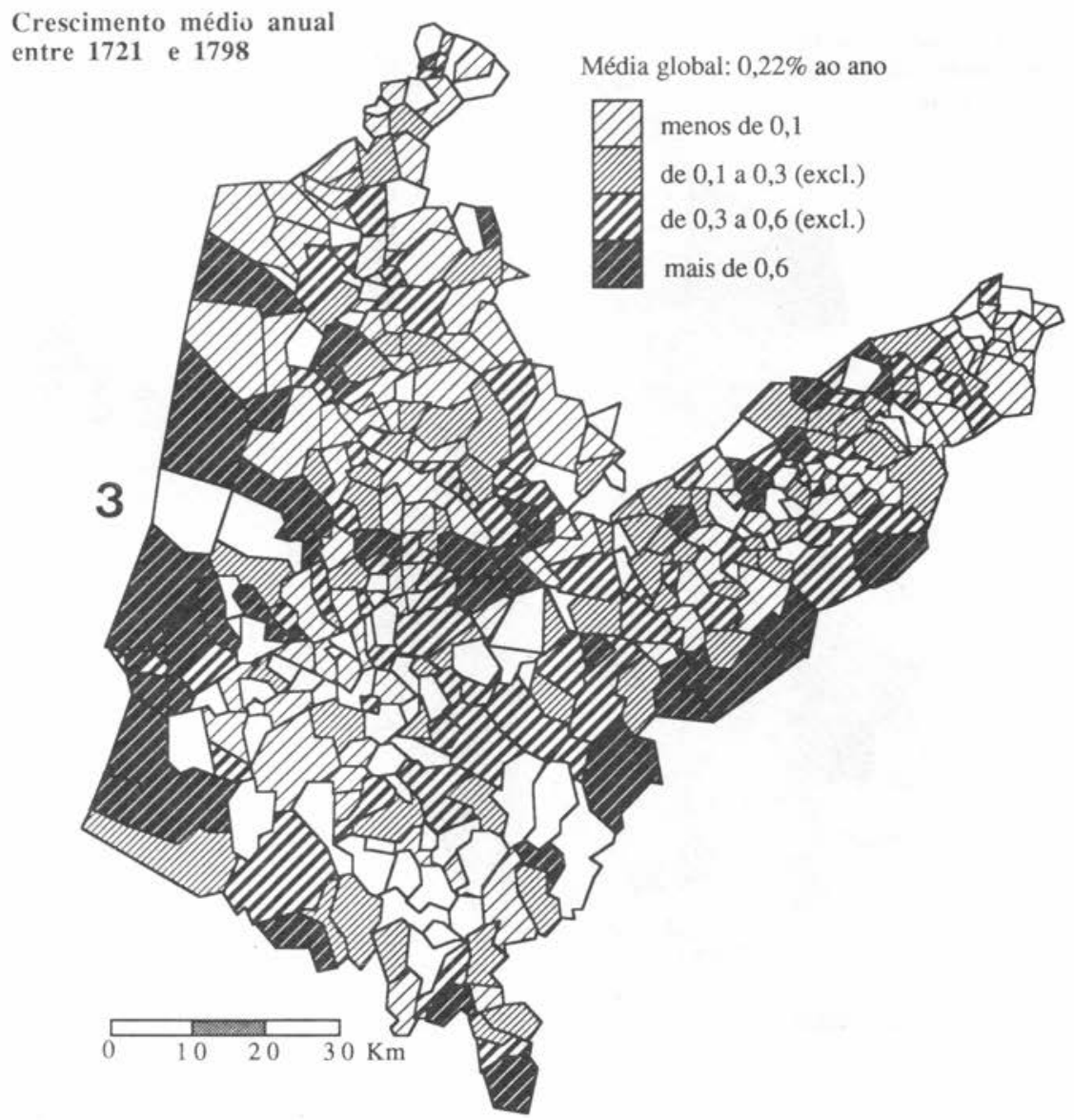




\section{A Diocese de Coimbra}

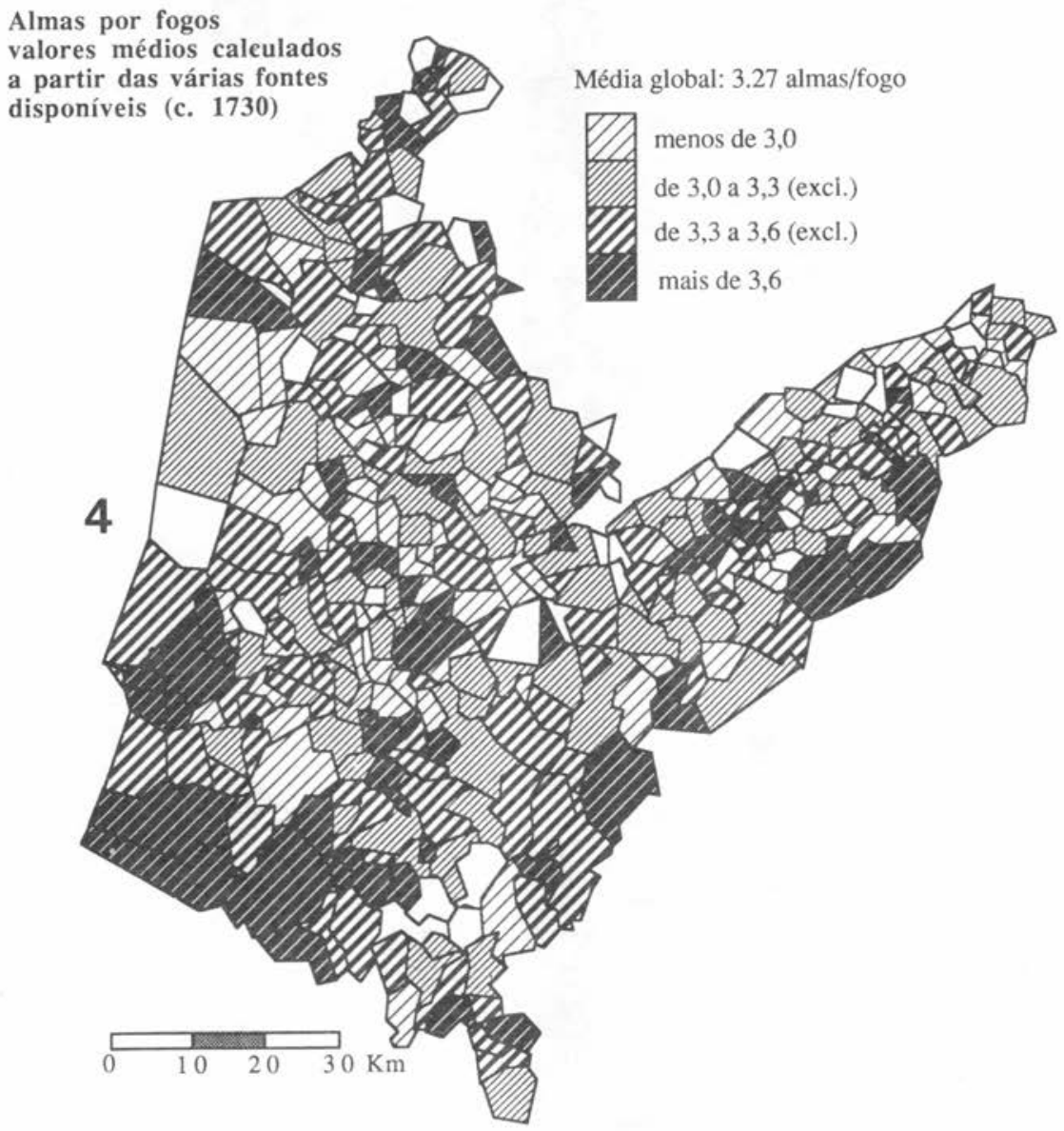


Revista de História das Ideias
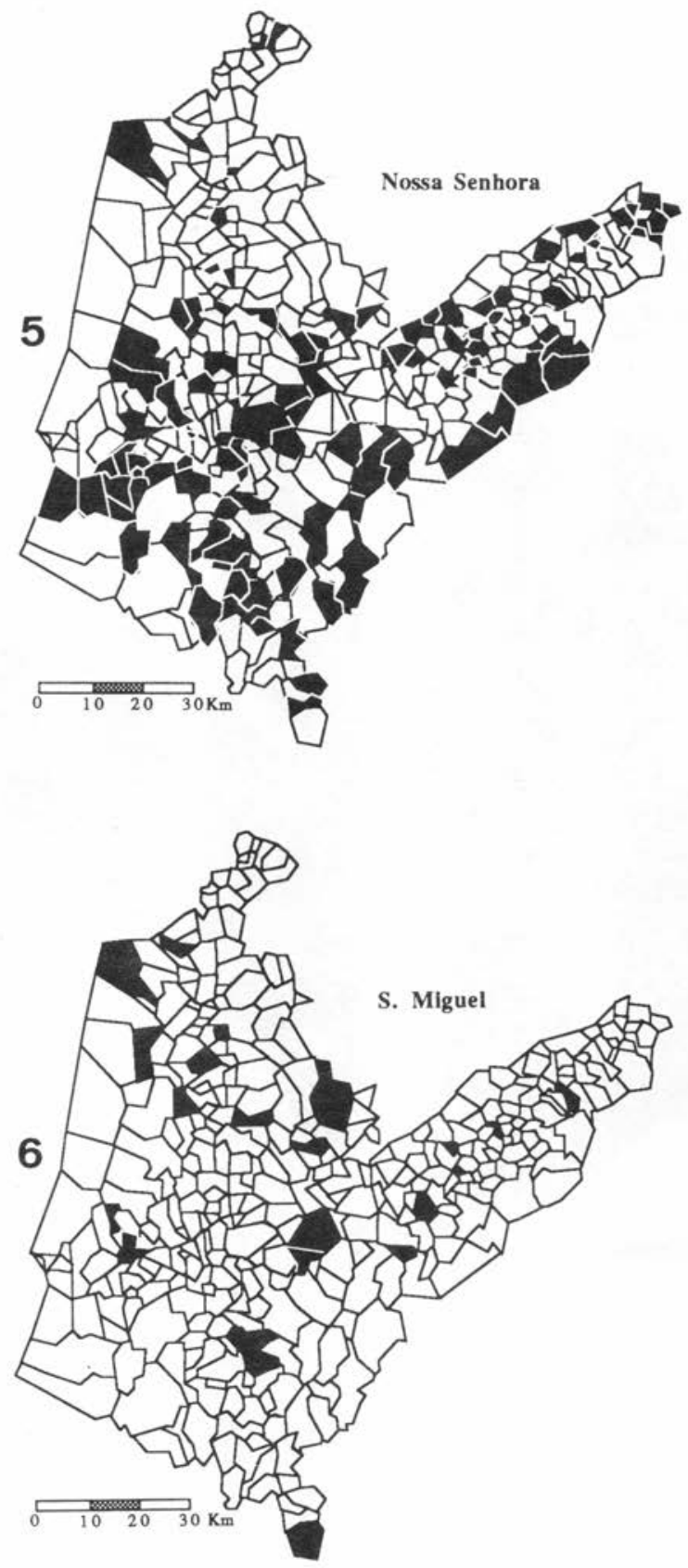
A Diocese de Coimbra
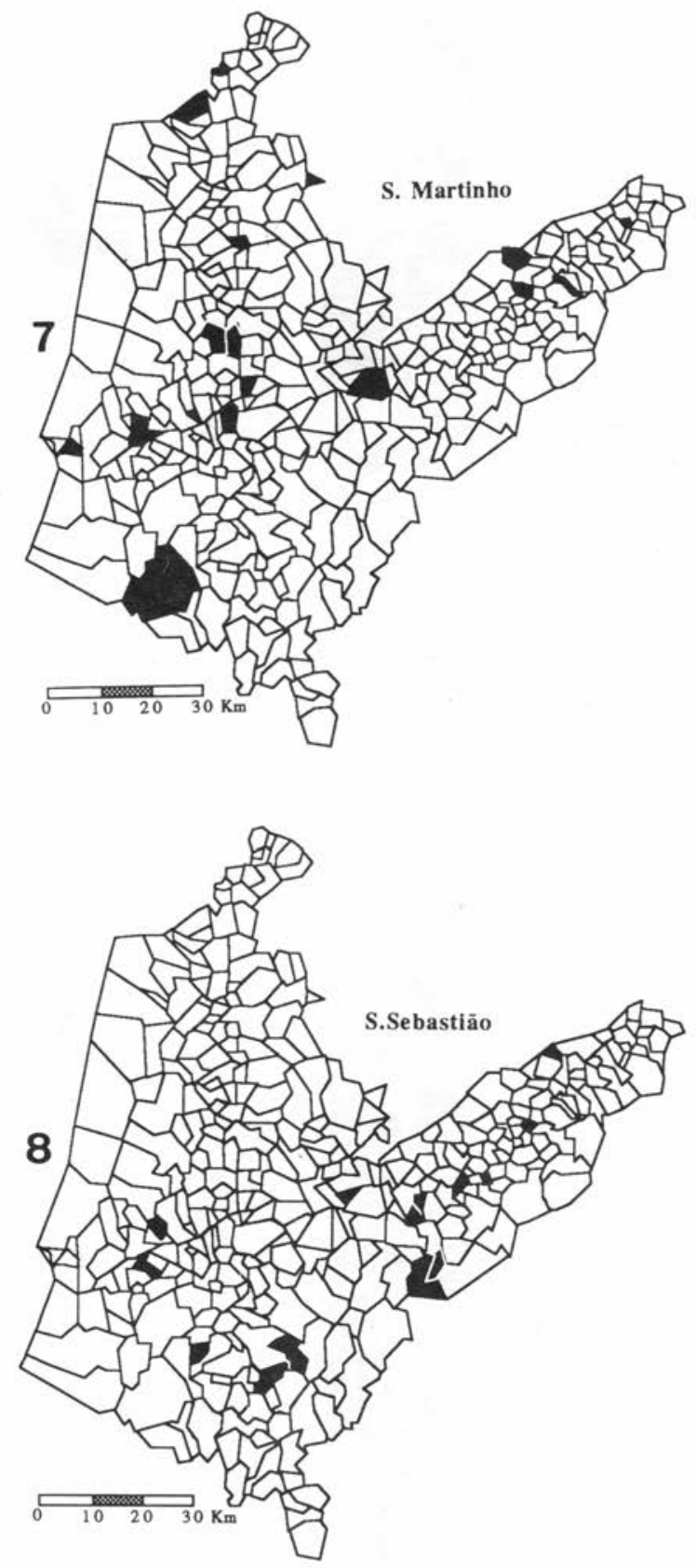
Revista de História das Ideias
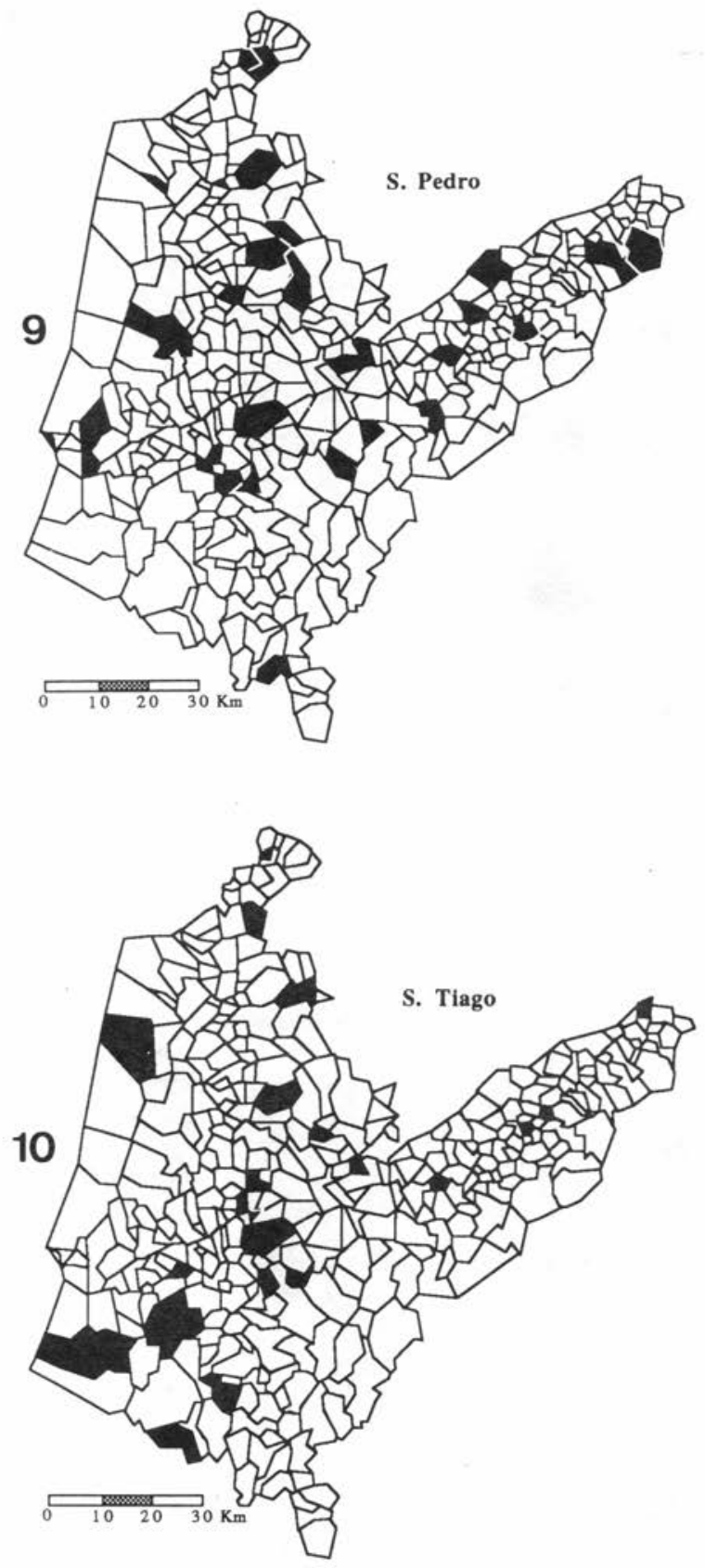
A Diocese de Coimbra
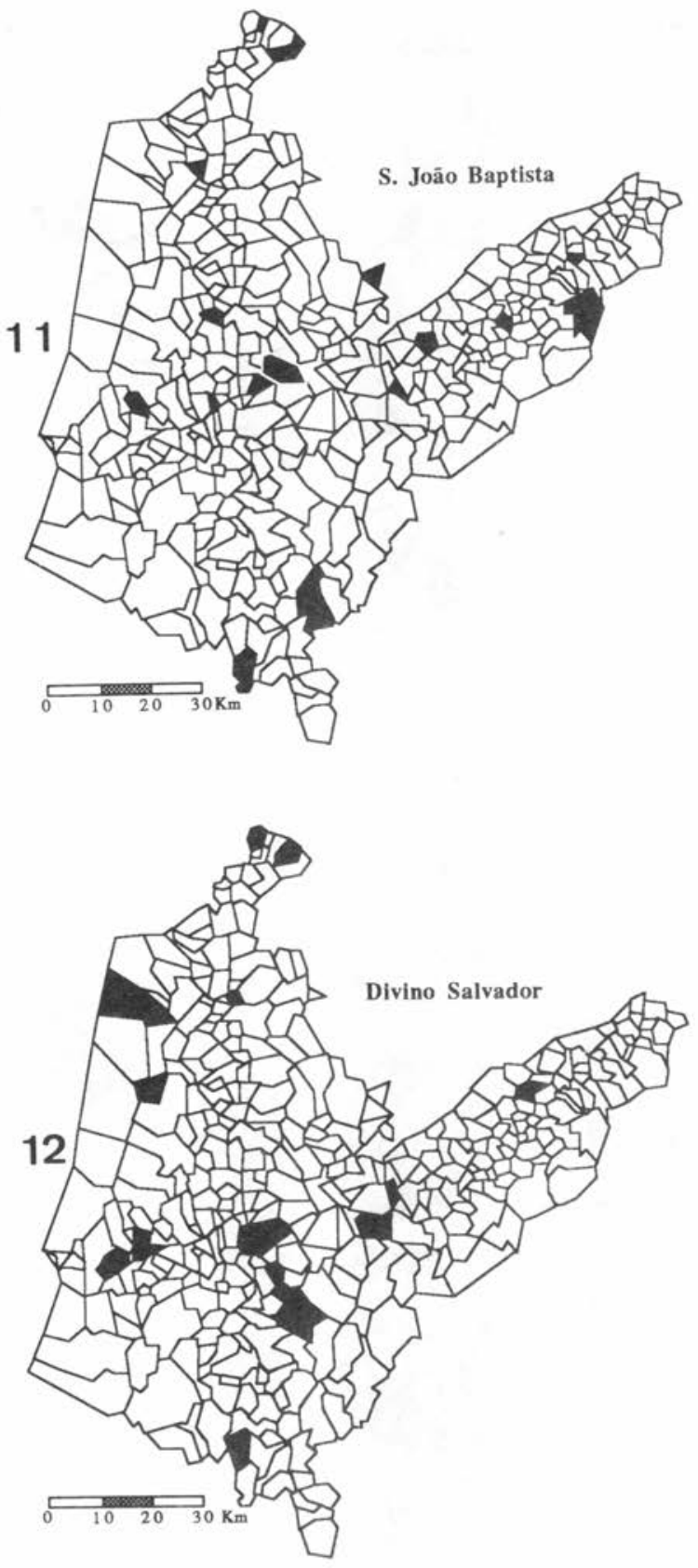
Revista de História das Ideias
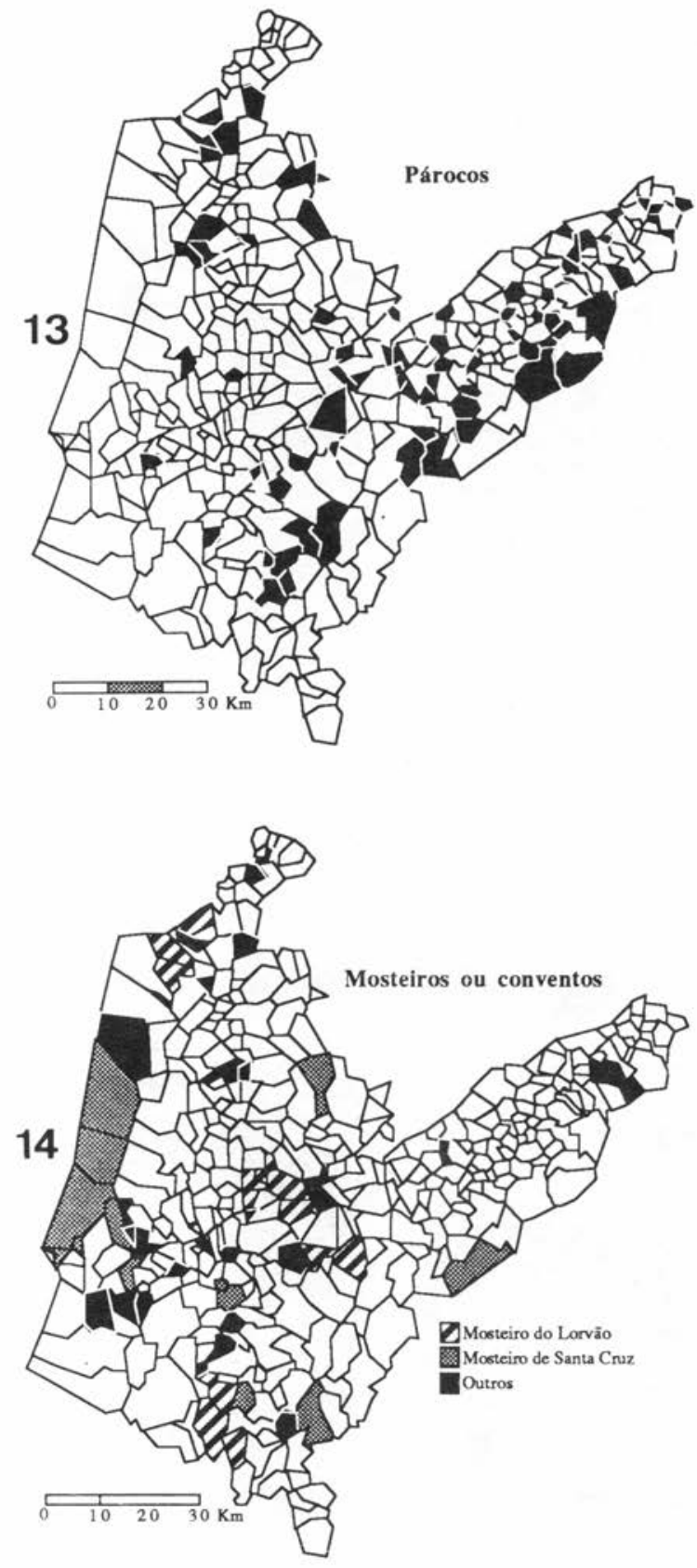
A Diocese de Coimbra
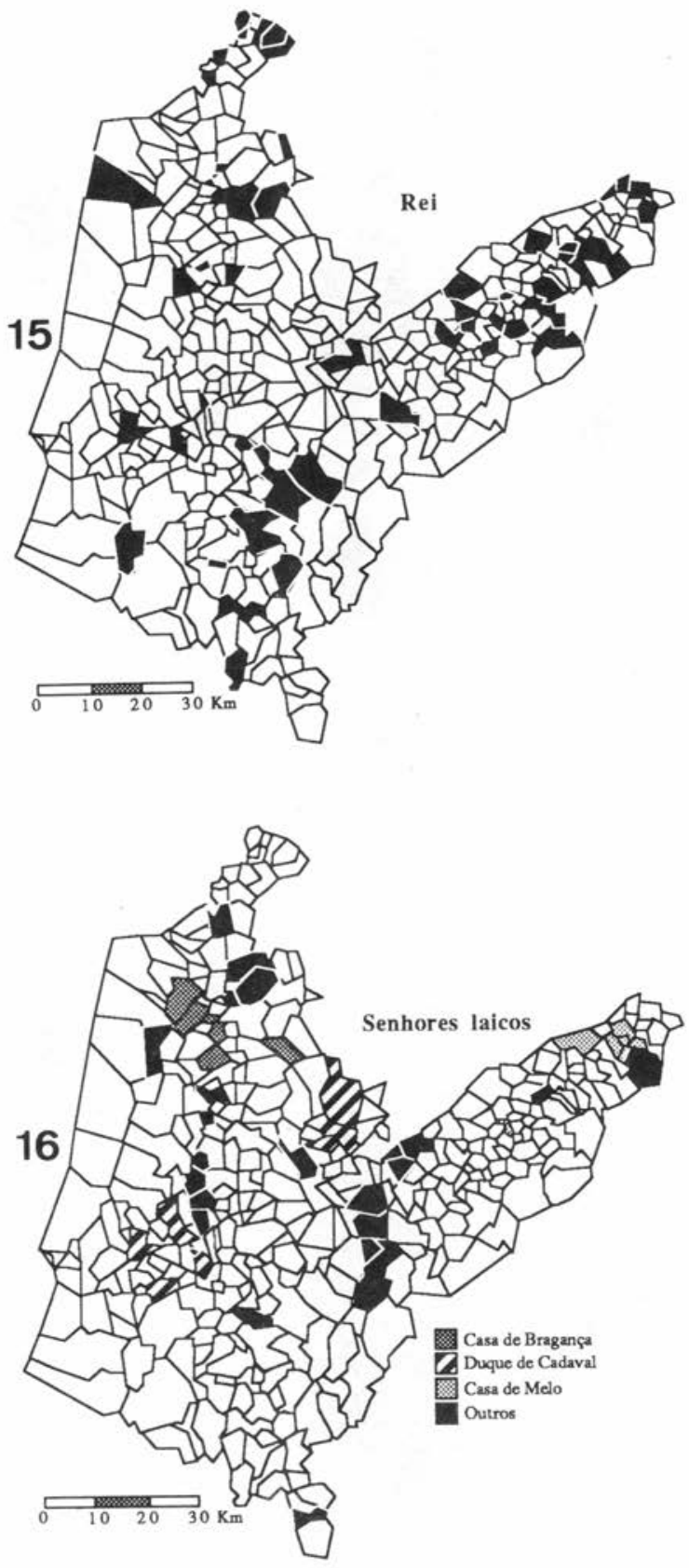
Revista de História das Ideias
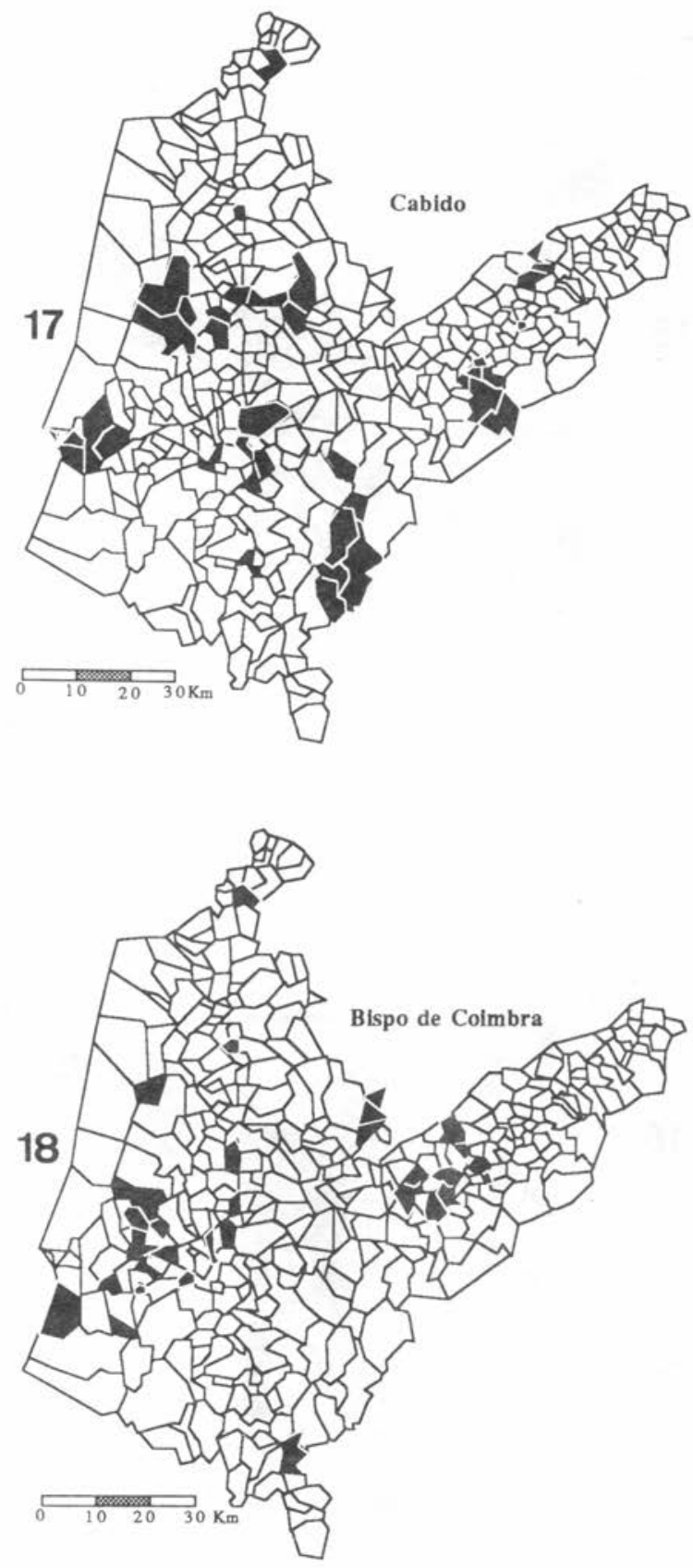


\section{A Diocese de Coimbra}
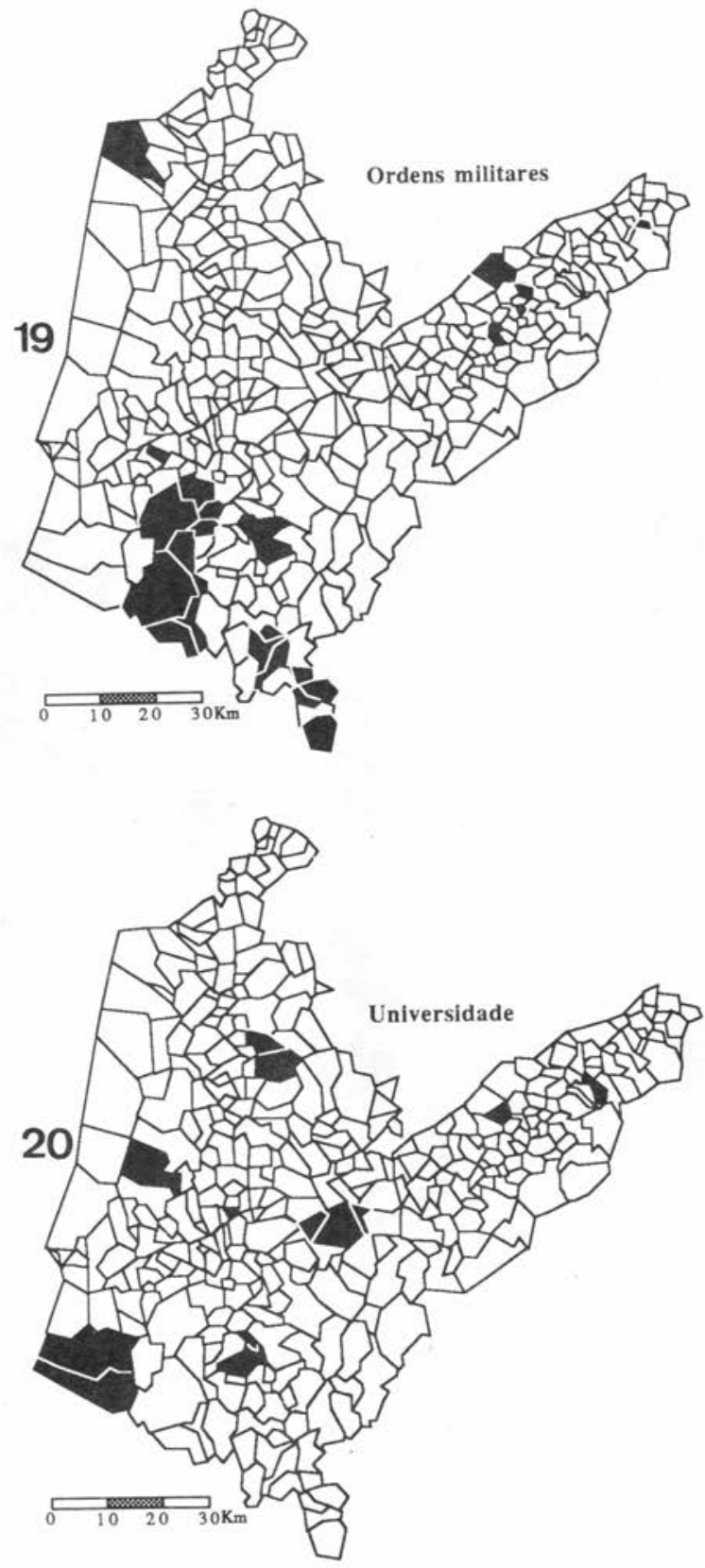


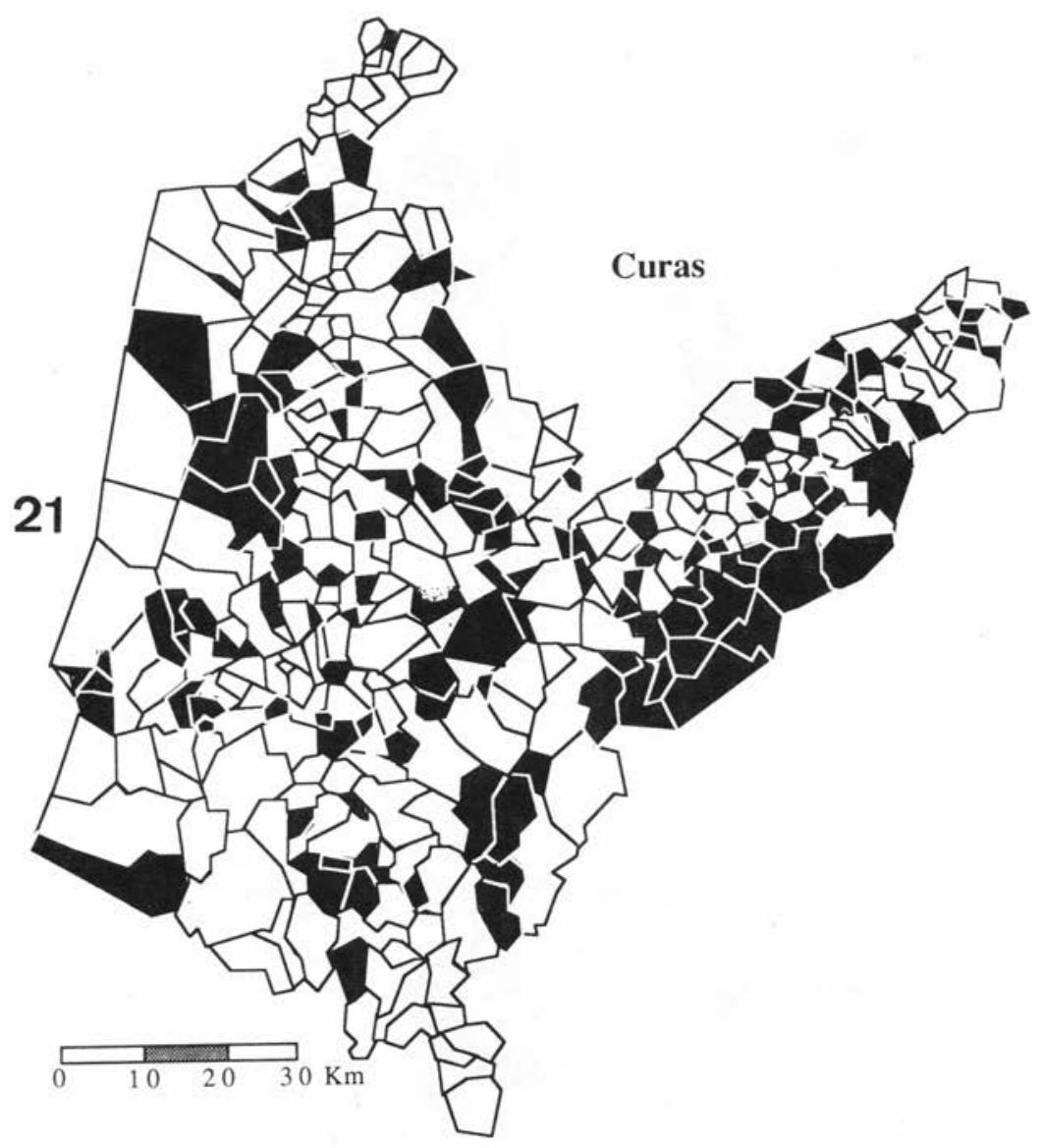




\section{A Diocese de Coimbra}

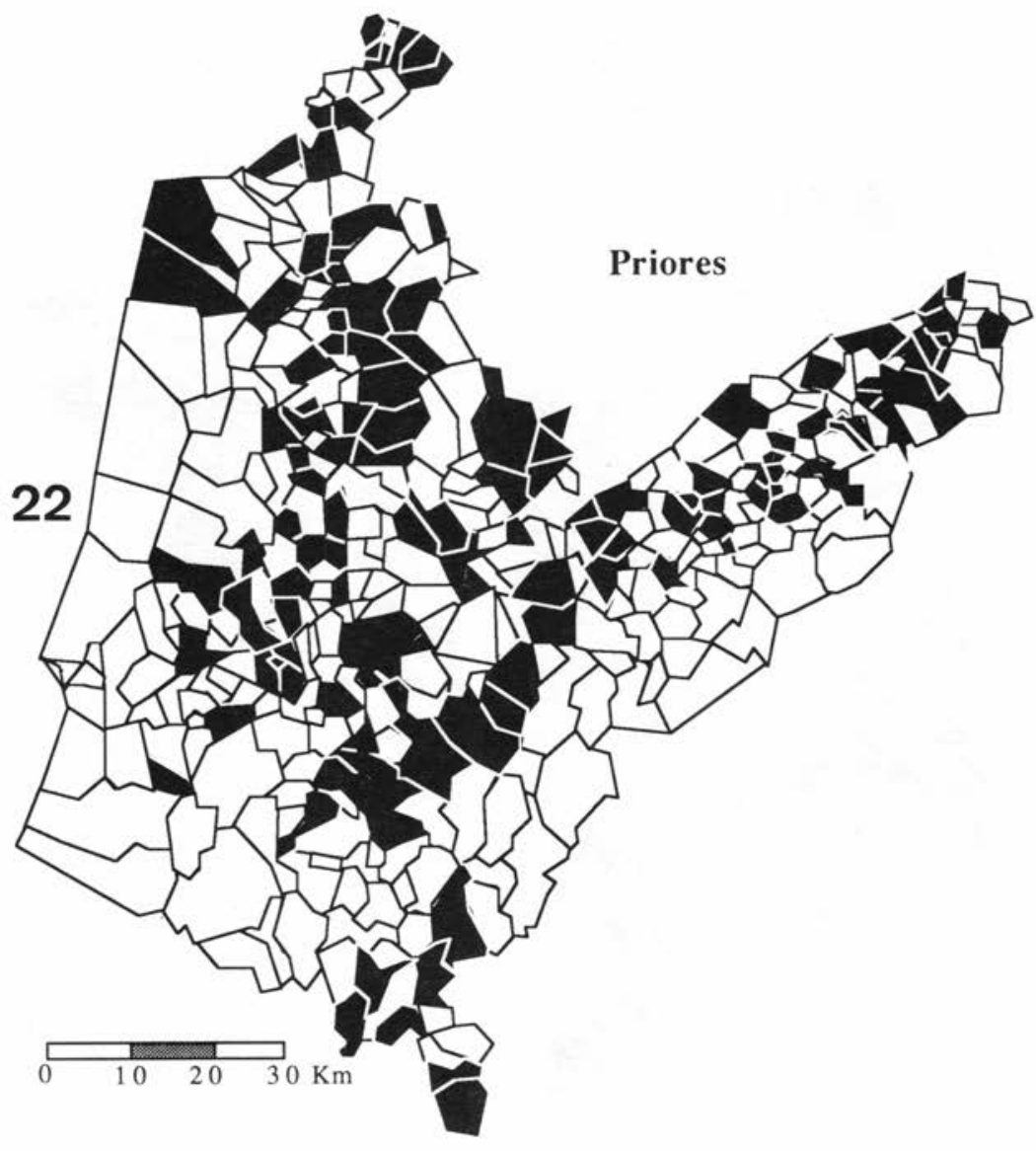




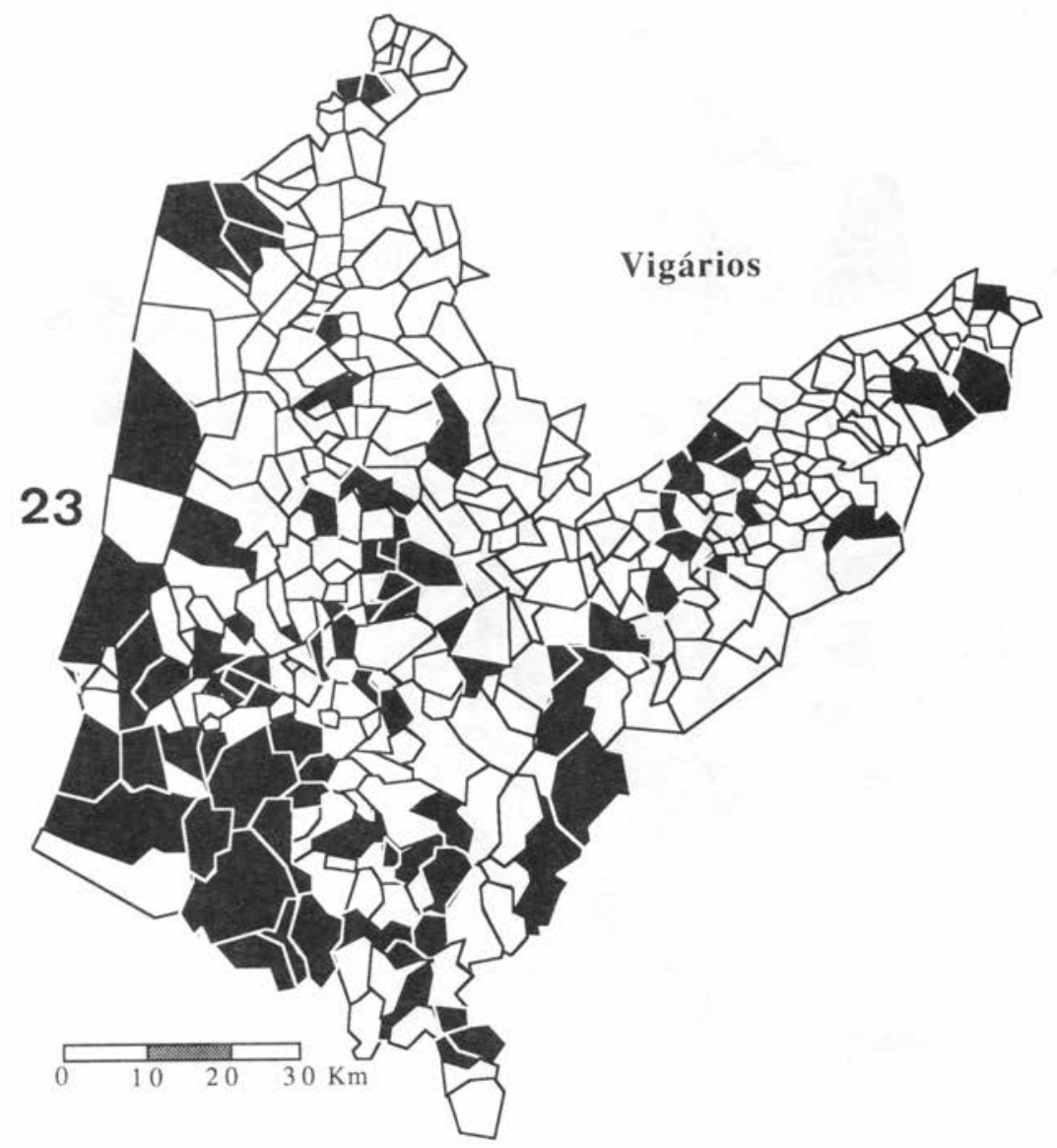




\section{A Diocese de Coimbra}

\section{APENDICE 1}

Este apêndice representa os valores cartografados nos mapas que ilustram este estudo. $\mathrm{O}$ seu objectivo é o de auxiliar a leitura dos mesmos e o de fornecer os valores reais por paróquia para consulta dos interessados.

Por cada uma das paróquias da diocese fornecemos:

1) o seu nome, seguido, entre parêntesis, do respectivo orago;

2) o arcediagado a que pertence: Penela, Seia, Vouga. As paróquias da cidade não pertenciam a nenhum dos três arcediagados rurais e são indicadas com "Coimbra». As paróquias do isento "nullius diocesis» de Santa Cruz e Grijó são assinaladas por "Isento» no lugar do arcediagado.

3) Cota: refere-se à quadrícula onde se encontra a paróquia na carta de referência que aqui publicamos extra-texto.

4) Área da paróquia em quilómetros quadrados, calculada através da reconstituição dos limites de cada paróquia pelo método descrito no texto (ver capítulo 1 ).

5) Valor representativo do número de almas (maiores de 7 anos) da paróquia, calculado pelo método descrito no capítulo 3 , em especial 3.2. Apresentamos o valor arredondado às dezenas.

6) Ano médio das fontes utilizadas no cálculo do valor representativo do número de almas da paróquia (ver capítulo 3 , ponto 2).

7) Densidade populacional dada em almas (maiores de 7 anos) por quilómetro quadrado. Este valor está em branco naquelas paróquias em que não possuíamos contagens de almas ou onde não foi possível determinar a área.

8) Coeficiente de almas por fogo na paróquia, fazendo a média dos coeficientes obtidos nas várias fontes disponíveis para essa paróquia (ver capítulo 3).

9) Taxa média de crescimento anual percentual entre os valores de fogos fornecidos pelas informações de 1721 e os do censo de 1798 (com conversão de almas em fogos em 1721, quando necessário ver capítulo 3 ).

10) Título do pároco, obtido por comparação de várias fontes segundo o método descrito no capítulo 6 .

11) Entidade com direito de apresentar o pároco, segundo o Portugal Sacro-Profano.

Para além do carácter aproximativo dos valores demográficos. que pensamos ter sido delimitado claramente no texto, é provável que exista um certo número de erros nesta lista, que só pessoas com conhecimento mais aproximado de cada paróquia poderão detectar. Os autores agradecem todas as notícias de incorrecções ou informações complementares, que permitam corrigir as eventuais insufic:ências dos valores apresentados. 


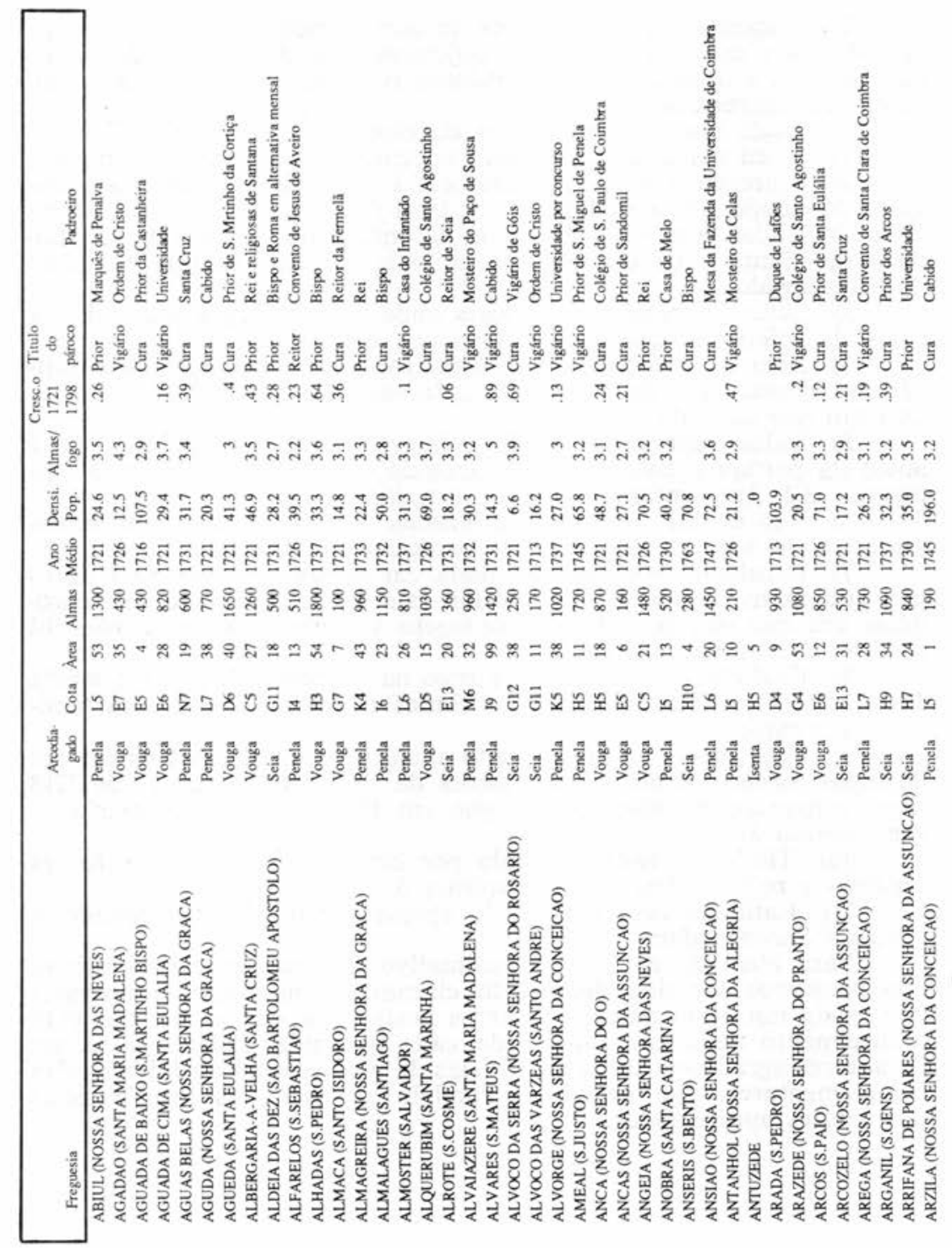




\section{A Diocese de Coimbra}

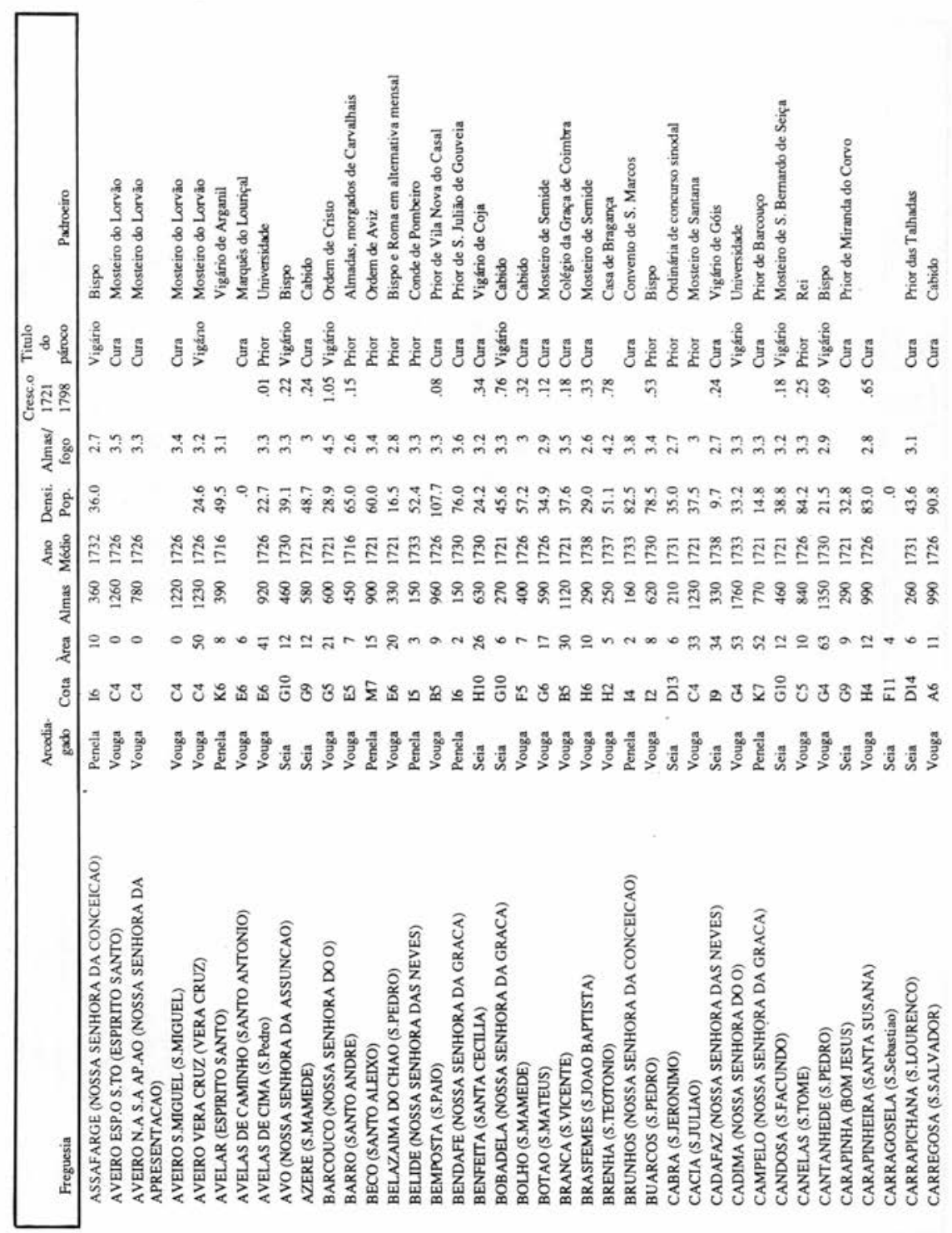




\section{Revista de História das Ideias}

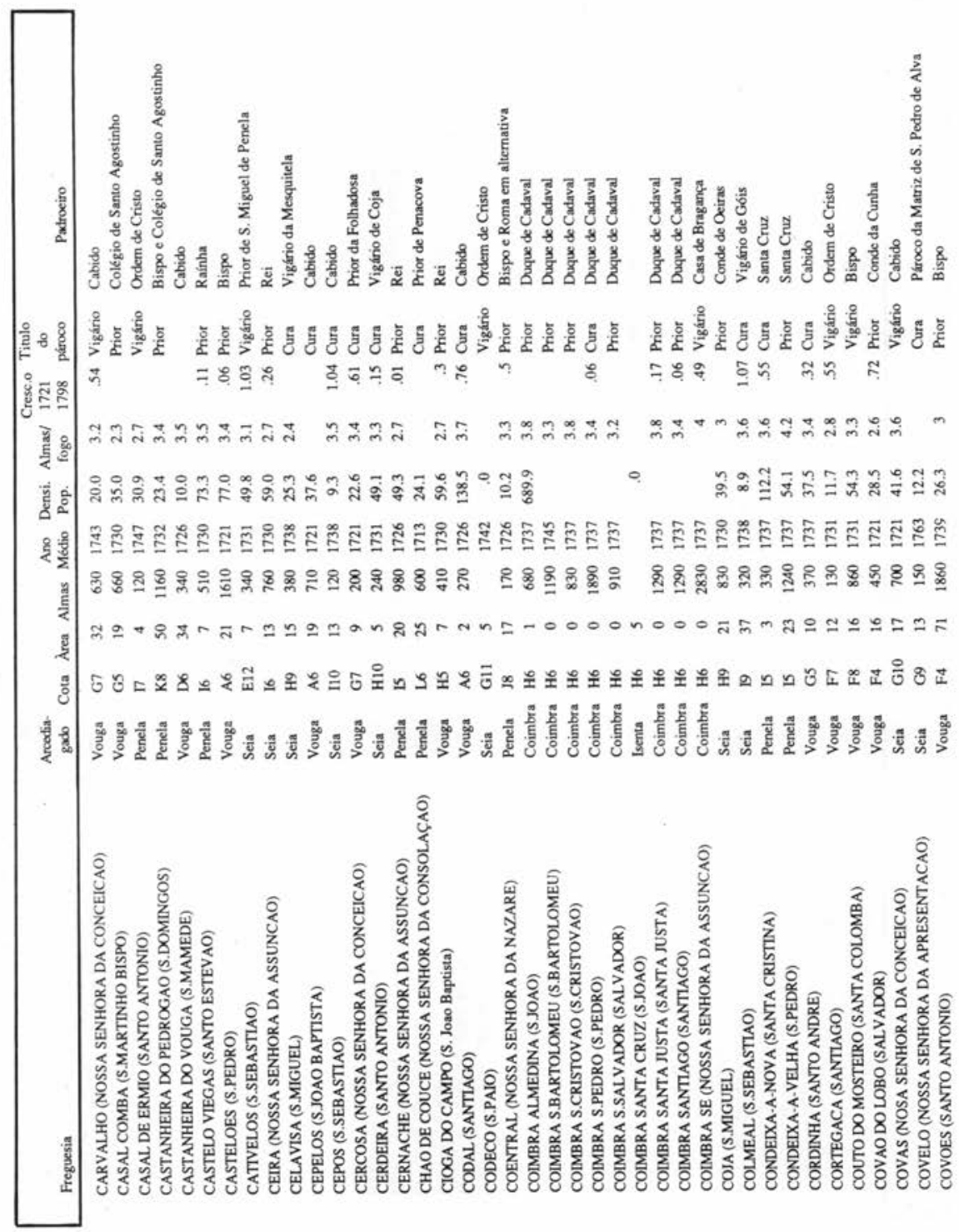




\section{A Diocese de Coimbra}

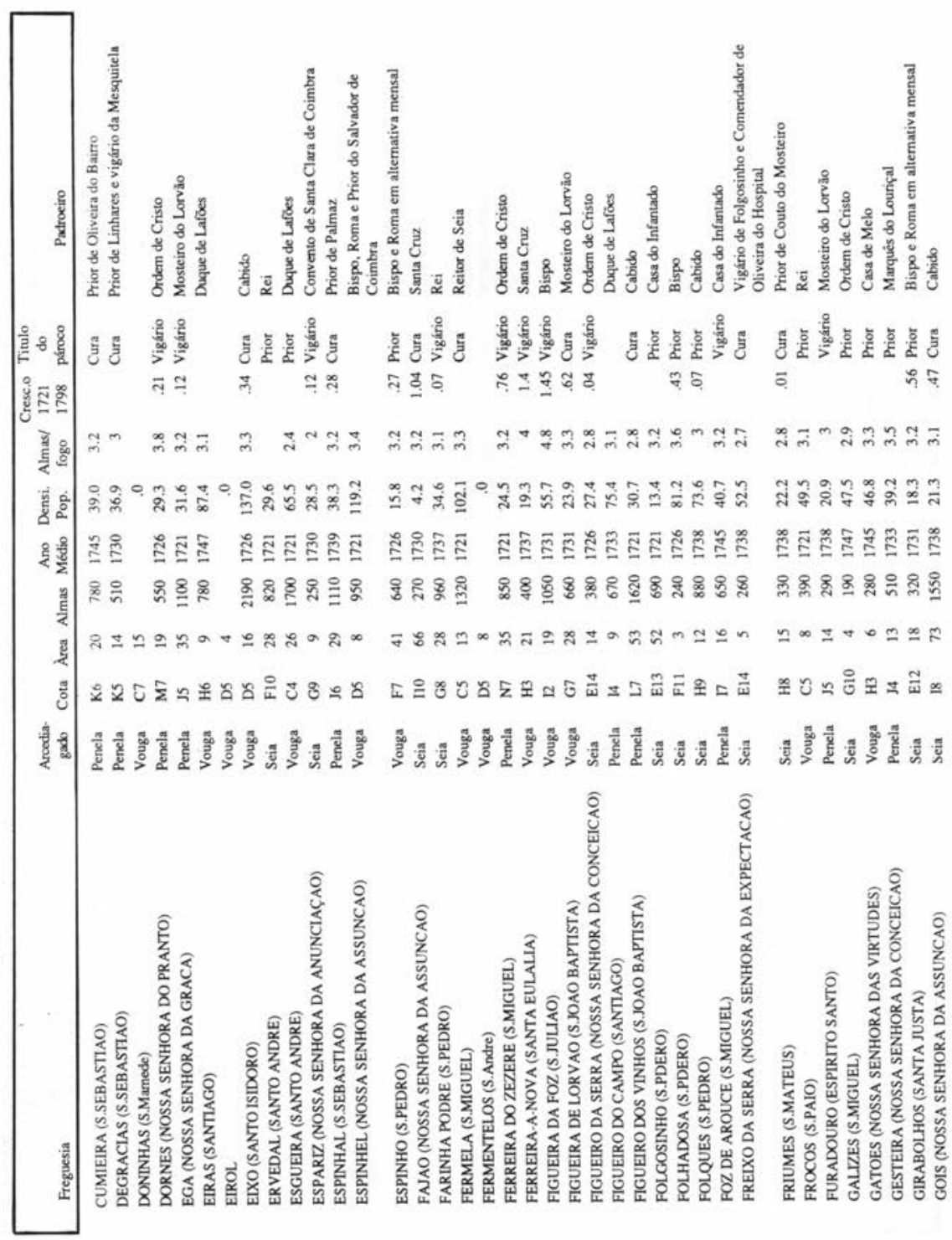




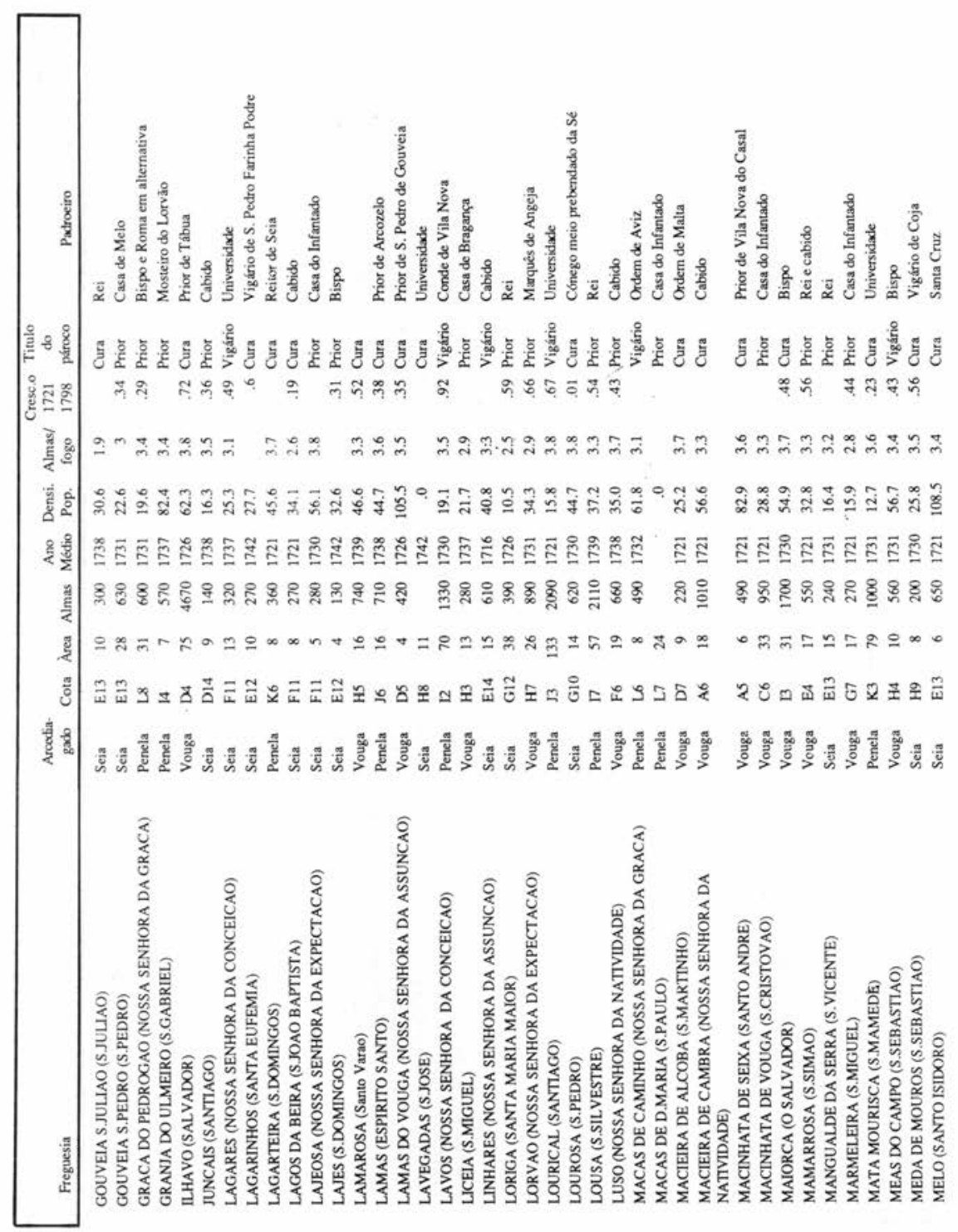




\section{A Diocese de Coimbra}

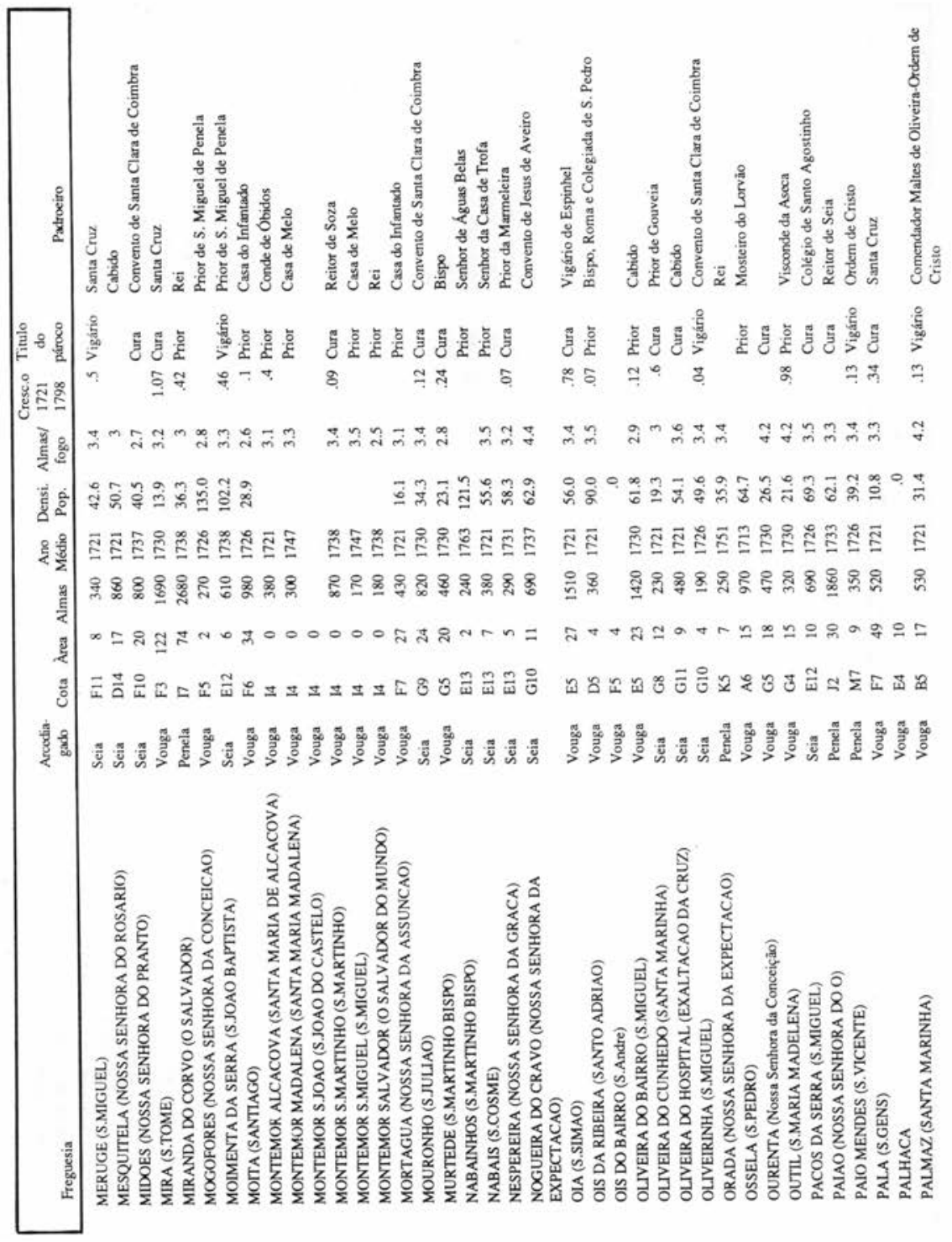




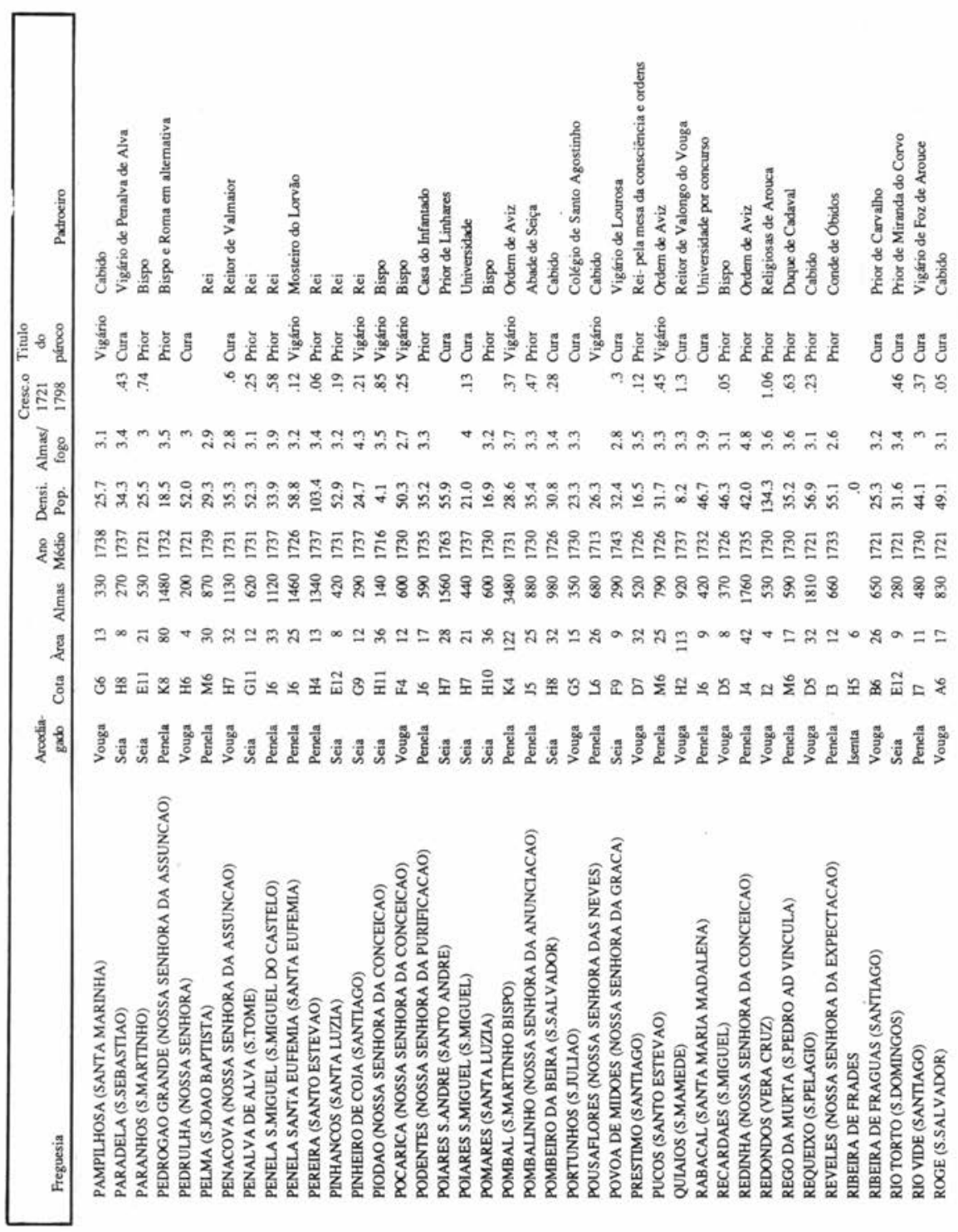




\section{A Diocese de Coimbra}

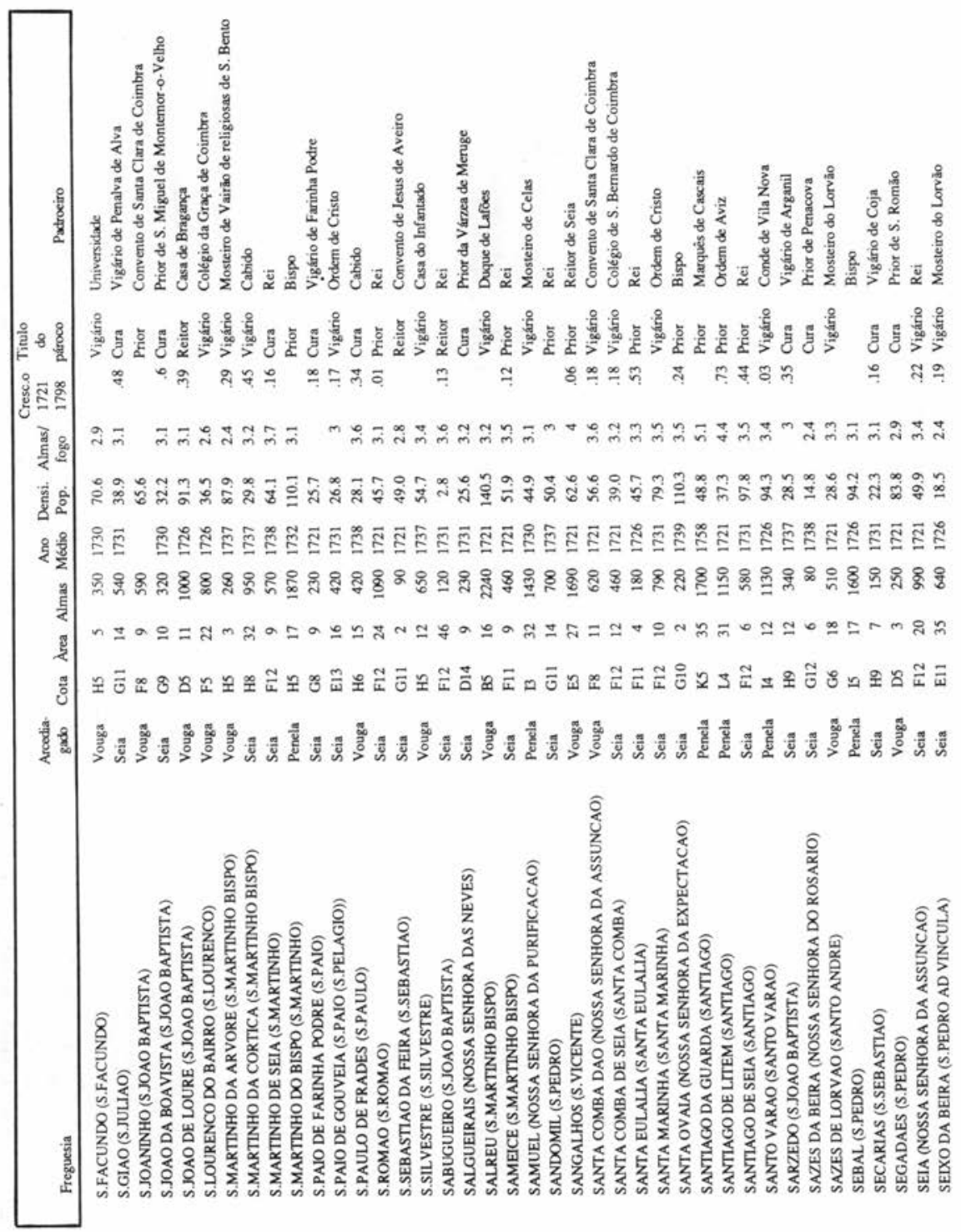


Revista de História das Ideias

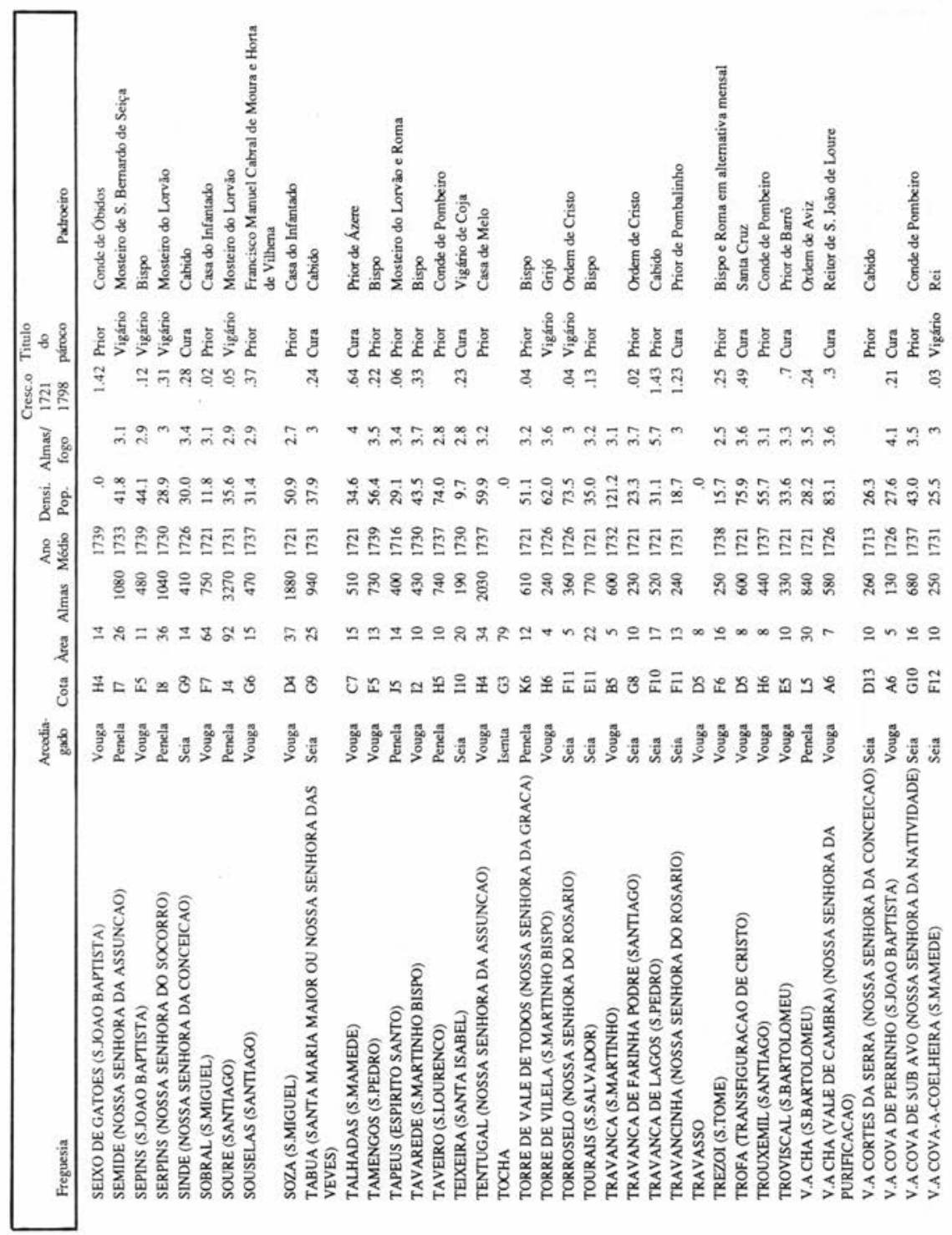




\section{A Diocese de Coimbra}

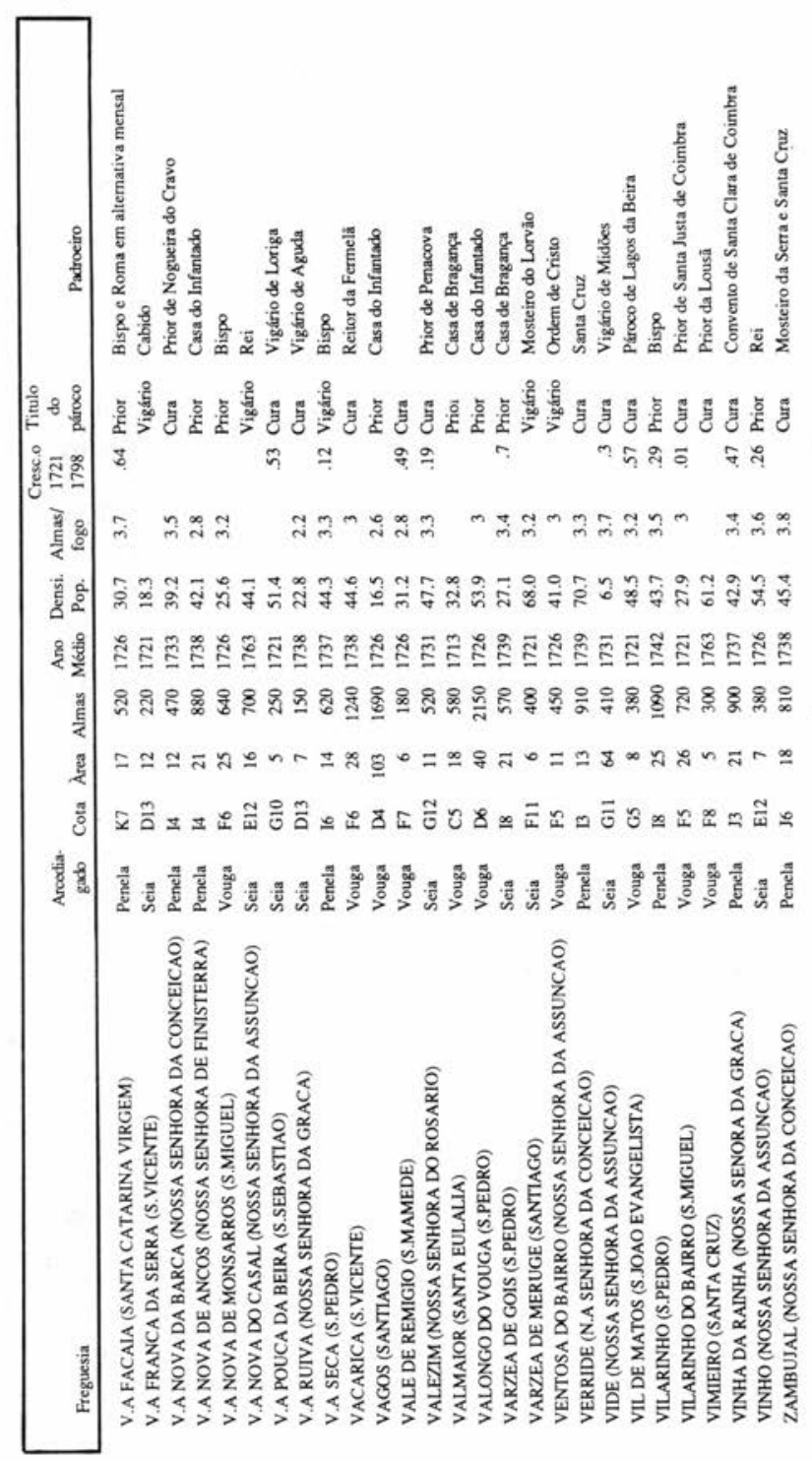




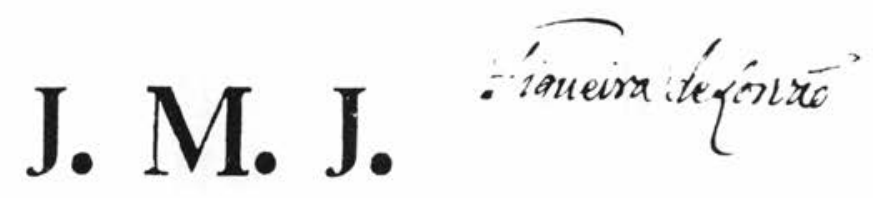

$\mathrm{D}$

A veridica, c exacta averiguaçaó fobre a materia conteû-

da nos interrogatorios abaixo infertos, depende, acerto

de huma geografia que fe pertende fazer: para o que, na forma da ordem, que tenho do Excellentiffimo, e Reverendiffimo Sunher Bifpo Conde, fe faz precizo, que $\mathrm{Vm}$. informe, com individuaçao, fobre o expofto em todos e cada hum dos ditos interrogatorios; a qual informaçaó com efta em carta fechada me remeterá a cfta Cidade com a mais poffivel brevidade por via do $\mathrm{P}$. Francifico da Silva affiftente no Collegio que foi da Companhia, fendo a mefma informaçaó jurada. Deos guarde a Vm. muitos annos. Cuimbra 25. de Fevereiro de 1763 .

\section{O Provizor do Bifpado.}

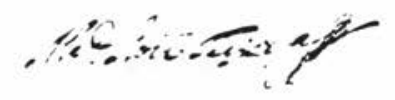

$O$ que fe pertende faber be o feguinte.

1. Como f: chama effa terra?

2. Qual he o Orago da Freguezia?

3. Que titulo tem o Paroco, fe he Prior, Reiior, ou Cura ?

4. Quem aprezenta a Igreja?

5. Quanto rende ao Paroco reduzido a dinheiro o que for em efpecie?

6. Quantas legoas difta de Lisboa, e quantas de Coimbra?

7 Quantos fogos tem toda a freguezia? 